University of Nebraska - Lincoln

DigitalCommons@University of Nebraska - Lincoln

\title{
Chronology of Advance and Recession Dynamics of the Southern Green Bay Lobe of the Laurentide Ice Sheet, South-Central Wisconsin, USA
}

\author{
Eric C. Carson \\ University of Wisconsin-Madison, eric.carson@wisc.edu \\ John W. Attig \\ University of Wisconsin-Madison \\ J. Elmo Rawling III \\ University of Wisconsin-Madison, elmo.rawling@wisc.edu \\ Paul R. Hanson \\ University of Nebraska - Lincoln, phanson2@unl.edu \\ Stefanie E. Dodge \\ University of Wisconsin-Madison
}

Follow this and additional works at: https://digitalcommons.unl.edu/natrespapers

Part of the Geology Commons, Glaciology Commons, Natural Resources and Conservation Commons, Natural Resources Management and Policy Commons, and the Other Environmental Sciences Commons

Carson, Eric C.; Attig, John W.; Rawling, J. Elmo III; Hanson, Paul R.; and Dodge, Stefanie E., "Chronology of Advance and Recession Dynamics of the Southern Green Bay Lobe of the Laurentide Ice Sheet, SouthCentral Wisconsin, USA" (2020). Papers in Natural Resources. 1242.

https://digitalcommons.unl.edu/natrespapers/1242

This Article is brought to you for free and open access by the Natural Resources, School of at DigitalCommons@University of Nebraska - Lincoln. It has been accepted for inclusion in Papers in Natural Resources by an authorized administrator of DigitalCommons@University of Nebraska - Lincoln. 
Published in Quaternary Research 95 (2020), pp. 142-153; doi: 10.1017/qua.2020.8

Copyright (c) 2020 University of Washington. Published by Cambridge University Press. Used by permission.

Submitted May 17, 2019; accepted January 29, 2020; published online March 25, 2020.

Supplementary materials follow the references.

\title{
Chronology of Advance and Recession Dynamics of the Southern Green Bay Lobe of the Laurentide Ice Sheet, South-Central Wisconsin, USA
}

\author{
Eric C. Carson, ${ }^{1}$ John W. Attig, ${ }^{1}$ J. Elmo Rawling III, ${ }^{1}$ Paul R. Hanson, ${ }^{2}$ \\ and Stefanie E. Dodge ${ }^{1}$
}

1. Wisconsin Geological and Natural History Survey, University of Wisconsin-Madison, Madison, Wisconsin, USA

2. Conservation and Survey Division, School of Natural Resources, University of Nebraska-Lincoln, Lincoln, Nebraska, USA

Corresponding author - Eric C. Carson, email eric.carson@wisc.edu

\begin{abstract}
We used a combination of accelerator mass spectrometry (AMS) radiocarbon dating, optically stimulated luminescence (OSL) age estimates, and stratigraphic data from cores collected along the southern margin of the Green Bay Lobe (GBL) of the Laurentide Ice Sheet to provide new information on the timing and dynamics of the end of advance of the GBL and the dynamics of the ice sheet while very near its maximum position. Coring at multiple sites along the margin of the GBL indicate that ice had reached a stable position near its maximum extent by $24.7 \mathrm{ka}$; that ice advanced several kilometers to the Marine Isotope Stage 2 maximum position sometime shortly after $21.2 \mathrm{ka}$; and that ice remained at or beyond that position through the time interval represented by an OSL age estimate of $19.2 \pm 3.2 \mathrm{ka}$. The timeline developed from these chronological data is internally consistent with, and further refines, AMS radiocarbon ages and OSL age estimates previously published for the
\end{abstract}


southern margin of the GBL. It also provides new chronological control on the expansion of the GBL from its late Marine Isotope Stage (MIS) 3 extent to its MIS 2 maximum.

Keywords: Green Bay Lobe, Laurentide Ice Sheet, chronology, MIS 2, Devils Lake

\section{Introduction}

During the past several decades, significant efforts have been made to constrain the chronology for the maximum extent of the various lobes of the Laurentide Ice Sheet (LIS) in the upper Midwest of the United States (Clayton and Moran, 1982; Mickelson et al., 1982; Attig et al., 1985, 2011; Maher and Mickelson, 1996; Syverson and Colgan, 2011; Carson et al., 2012a; Ullman et al., 2014; Curry et al., 2018; Heath et al., 2018). While the LIS likely has the largest inventory of numeric ages (in the form of radiocarbon, optically stimulated luminescence [OSL], and cosmogenic exposure dating) of any major ice sheet, very few of the available dates address the timing and behavior of ice at its absolute maximum position. This is particularly the case for lobes of the LIS in Wisconsin (Fig. 1), where permafrost conditions inhibited the growth of large, woody vegetation before and for several thousands of years after the peak of the late Wisconsin (Marine Isotope Stage [MIS] 2) glaciation (Clayton et al., 2001; Batchelor et al., 2019). This is illustrated by the work of Heath et al. (2018), which presented a compilation of more than 500 radiocarbon, OSL, and cosmogenic ages from the southern LIS addressing the advance and retreat of various lobes of the LIS. Despite the size of the data set, not a single numeric date was available to tightly constrain the end of the advance of the Green Bay Lobe (GBL) or any lobe immediately to the north in Wisconsin. This study seeks to address this gap in our knowledge. Continued refinement of the absolute chronologies of advance and retreat of lobes of the LIS will improve our understanding of ice dynamics (synchronous vs. asynchronous behavior of adjacent lobes) and response of the southern margin of the LIS to hemispheric or global climate change.

The various lobes of the southern LIS terminate on a variety of geomorphic settings. Several lobes terminate on low relief landscapes formed from glaciogenic sediment from earlier Quaternary glaciations, which limits the likelihood of preserving chronological data regarding the timing of advance and retreat right at the maximum position. However, some lobes - including parts of the Superior, Chippewa, Wisconsin Valley, Green Bay, and Saginaw Lobes (Fig. 1) - terminated at or near enough to the maximum extent of all Quaternary glaciations that the glacial margins intersected a more varied topographic and geomorphic surface. Recent researchers (e.g., Attig et al., 2011; Carson et al., 2012a; King et al., 2014; Schaetzl et al., 2017) have demonstrated that this variety of geomorphic settings provides enhanced opportunities for preserving information about the timing and nature of ice advance and retreat at the maximum position. 

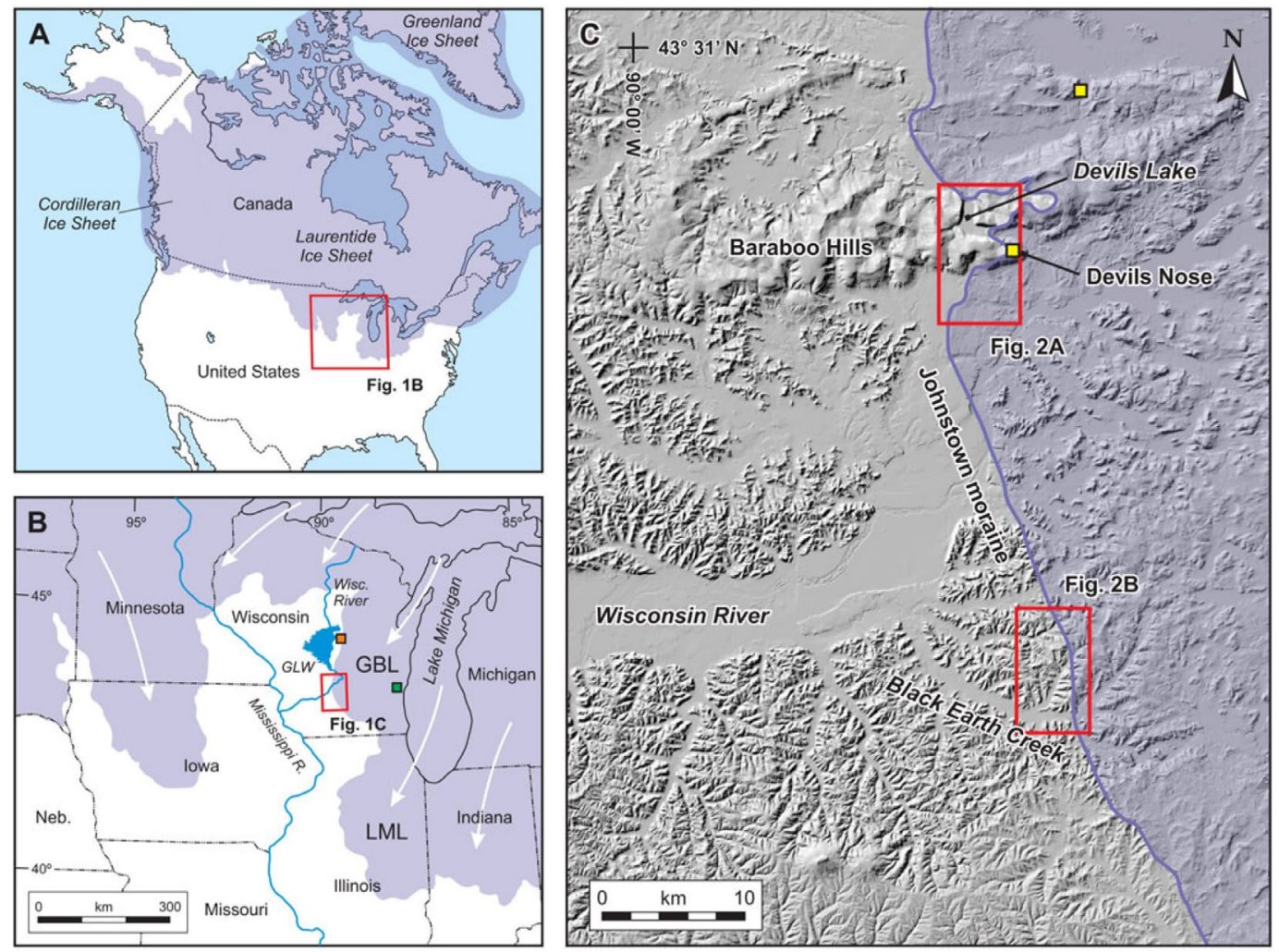

Figure 1. Study area. On all maps in Figures 1 and 2, purple shading indicates glaciated area. (A) Southern margin of the Laurentide Ice Sheet (LIS) in the U.S. Midwest. (B) U.S. Midwest, showing the MIS 2 maximum extent of the LIS with generalized flow lines in white. Relevant lobes of the LIS: GBL, Green Bay; LML, Lake Michigan. The Wisconsin River flows south through the central portion of Wisconsin and was dammed during the MIS 2 glaciation to form glacial Lake Wisconsin (GLW). Orange square identifies study area of Ceperley et al. (2019), green square identifies study area of Carlson et al. (2018). (C) Baraboo Hills and Wisconsin River valley, showing extent of GBL in the area. The maximum extent of all glaciations in the study area is marked by the MIS 2 "Johnstown moraine." Red boxes identify locations of detailed maps in Figure 2. Yellow squares identify sampling sites for Ullman et al. (2014).

The southern portion of the GBL is a striking example of a lobe of the LIS that abutted a wide range of geomorphic and depositional settings. Within a stretch of $\sim 40 \mathrm{~km}$, the maximum position of the glacier contacted high-relief uplands composed of Precambrian quartzite, the broad lower Wisconsin River valley, and a deeply incised Paleozoic sedimentary sequence exposed at the earth's surface of a terrain unglaciated beyond the MIS 2 maximum position. Here, we present stratigraphic and chronological data from a spectrum of depositional settings that provide new insight into (1) the behavior of the GBL as it neared the MIS 2 maximum position; (2) the timing of the end of advance of the GBL; and (3) the behavior of the GBL at the start of retreat from the maximum position. Coupled 
with previously published data from this area, we present a refined view of the chronology and dynamics of the GBL at and near its MIS 2 maximum extent.

\section{Geographic and Geologic Setting}

The GBL of the Laurentide Ice Sheet flowed southwestward from the Green Bay-Lake Michigan lowland to cover the south-central and eastern portions of Wisconsin during the MIS 2 glaciation (Fig. 1B). The southern margin of the GBL intersects several prominent landscape/geomorphic features at its margin: the Baraboo Hills, a prominent upland formed by resistant quartzite; the broad valley of the lower Wisconsin River; and deeply incised Paleozoic sedimentary rocks. In this area, the Johnstown moraine marks the maximum MIS 2 ice position (Chamberlin, 1883; Alden, 1918; Martin, 1932; Mickelson et al., 1982; Fig. 1C).

The Baraboo Hills are composed of the resistant late Proterozoic Baraboo quartzite (Dalziel and Dott, 1970; Medaris et al., 2003) and form a prominent topographic high, rising as much $200 \mathrm{~m}$ above the surrounding terrain. The South Range of the Baraboo Hills is cut by the 6-km-long, 1-km-wide Devils Lake gorge. In situ sandstone deposits in the gorge demonstrate that it was cut before the late Cambrian (Salisbury and Atwood, 1900; Trowbridge, 1917). Moraines dam the gorge at both ends, though the central portion of the gorge was apparently never glaciated (Salisbury and Atwood, 1900; Trowbridge, 1917; Attig et al., 1985; Clayton and Attig, 1989, 1990); these moraine dams form Devils Lake, which has persisted since the end of local glaciation (Fig. 1C). At least $120 \mathrm{~m}$ of Pleistocene sediment fills the gorge, and the walls of the gorge rise at least another $150 \mathrm{~m}$ above the surface of Devils Lake; talus slopes of the Baraboo quartzite extend down the walls of the gorge to lake level in many places within the gorge.

The Wisconsin River flows south across much of Wisconsin. At the Baraboo Hills, the river diverts around the east end of the range. On the south side of the range, the river occupies the broad lower Wisconsin River valley and flows west to its confluence with the Mississippi River (Fig. 1). Advancing ice of the GBL dammed the Wisconsin River by overrunning the east end of the Baraboo Hills and blocking the Devils Lake gorge, forming the expansive glacial Lake Wisconsin (Fig. 1B) (Warren, 1874; Chamberlin, 1883; Clayton and Attig, 1989, 1990) and a host of smaller lakes. The main basin of glacial Lake Wisconsin occupied a broad area to the north of the Baraboo Hills, although smaller basins of the lake occurred in the central lowland of the Baraboo Hills in proximity to Devils Lake.

In the study area, the MIS 2 advance of the GBL marked the greatest regional advance of any Quaternary glaciation. Extending to the west across southwestern Wisconsin is the unglaciated "Driftless Area," so named for the lack of glacial sediment (Alden, 1918; Cline, 1965; Olcott, 1972; Clayton and Attig, 1997; Knox, 2019). In the study area, nearly flat-lying Paleozoic sedimentary strata were deeply dissected by fluvial incision before the Quaternary glaciations. While this regional incision is largely obscured behind (to the east of) the glacial margin due to the thick mantle of glacial sediment, it is the defining characteristic of the landscape south and west of the glacial margin. 


\section{Study sites}

Devils Lake gorge

The advance of the GBL across the eastern end of the Baraboo Hills created a convoluted glacial margin in the vicinity of the Devils Lake gorge. While the Johnstown moraine is often no more than a few meters high throughout the study area (Clayton and Attig, 1990, 1997), it is much larger both in terms of topographic relief and volume where it crosses the north and south ends of Devils Lake gorge. Where the moraine crosses the north end of the gorge, it rises $\sim 25 \mathrm{~m}$ above the surface of Devils Lake, $45 \mathrm{~m}$ higher than the glaciated terrain immediately north of the gorge; where the moraine crosses the south end of the gorge, it is as much as $60 \mathrm{~m}$ higher than the glaciated terrain south of the gorge. The moraine is as much as $600 \mathrm{~m}$ wide in the two places where it crosses the gorge. Where the moraine crosses the south end of Devils Lake gorge, it has a flat surface that is roughly $300 \mathrm{~m}$ wide with a 2 to $3 \mathrm{~m}$ ridge of sediment superimposed on it and scattered kettle hole depressions on the surface. Visual inspection of the moraine at the north end of the gorge where the outlet from Devils Lake cuts through the moraine indicates that it is composed of cobbly diamicton interpreted to be till. No similar exposure occurs in the moraine at the south end of the gorge. While Lundqvist et al. (1993) evaluated the stratigraphy and sedimentology of the Johnstown moraine in the vicinity of the Baraboo Hills, little is known about the subsurface stratigraphy of these two prominent sections that block the ends of the Devils Lake gorge.

Ice blocked both ends of the gorge but did not cover the upland surfaces immediately to the east and west of the gorge (Fig. 2A). Ice that blocked the north end of the gorge separated Devils Lake at its full glacial stage from the larger glacial Lake Wisconsin. When the GBL was at its maximum position, the elevation of Devils Lake was raised by at least $27 \mathrm{~m}$ relative to the modern lake level, as inferred from the upper limit of erratic boulders found in the quartzite talus on the west bluff of the gorge (Salisbury and Atwood, 1900). Following retreat of MIS 2 ice from the north and south ends of the gorge, the lake level fell to its modern level as a result of downcutting through the moraine at the north end of the gorge. Several discrete bench surfaces can be found within the impounded portion of the Devils Lake gorge roughly 15 to $18 \mathrm{~m}$ above the modern lake level (see supplementary material following the references). Among these is a linear bench that extends along the base of the north-facing talus slope in the southwest corner of the gorge. The talus presumably extends for some distance below the ground surface and is buried by the late Quaternary sediment that forms the bench. 

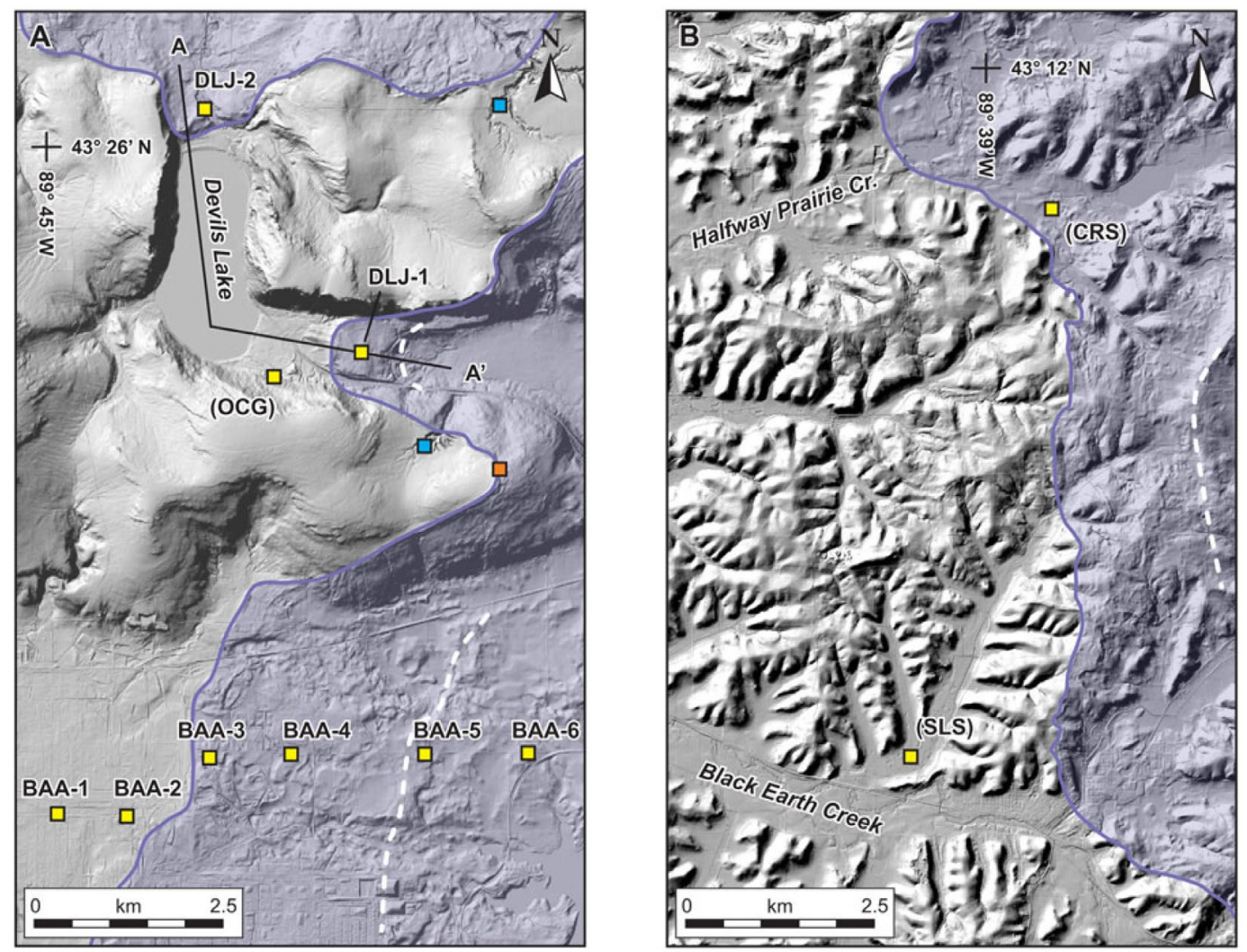

Figure 2. Detail maps of study areas. (A) Devils Lake gorge, which cuts through the Baraboo Hills. Coring sites as discussed in text are identified by yellow squares: BAA, Badger Army Ammunition; DLJ, Devils Lake Johnstown; OCG, Old Campground. A-A' line locates cross section in Figure 3. Orange square identifies sampling site for Ullman et al. (2014) at Devils Nose. Blue squares identify sampling sites for Attig et al. (2011). Core stratigraphy is shown as follows: DLJ, Figure 3; OCG, Figure 4; BAA, Figure 5A. (B) Halfway Prairie Creek and Black Earth Creek, tributaries to the lower Wisconsin River south of the Baraboo Hills. Coring sites as discussed in text are identified by yellow squares: CRS, Cross Plains; SLS, Swamplovers. Core stratigraphy for CRS and SLS is shown in Figure $5 \mathrm{~B}$ and $\mathrm{C}$, respectively. In both images, white dashed lines identify premaximum ice-marginal positions behind the MIS 2 maximum.

Wisconsin River valley

Immediately south of the Baraboo Hills, the Johnstown moraine crosses the broad valley of the Wisconsin River (Figs. 1C and 2A). Straddling the Johnstown moraine in the river valley is the site of the former Badger Army Ammunition plant, a facility that was used by the U.S. Army for production of munitions. The decommissioning of the plant, with ownership being returned to several local entities, allowed public access to the property for the first time in more than half a century. As mapped by Clayton and Attig (1990), the eastern portion of the former plant is characterized by till of the GBL that is meters to tens of meters thick; the central portion of the area contains thicker till forming the Johnstown moraine, 
and the western portion of the area is composed of sand and gravel outwash sourced from the adjacent GBL. Lundqvist et al. (1993) described the stratigraphy in a pit exposure into the Johnstown moraine immediately south of the Badger Army Ammunition property. They reported a mix of water-lain sediment interpreted to have been deposited in an esker and till, all deposited on the same outwash that extends westward beyond the moraine.

\section{Tributaries to the Wisconsin River}

West of the Johnstown moraine and south of the Wisconsin River, the landscape is dominated by a preglacial fluvial incision into the Paleozoic sedimentary rocks. Individual tributary valleys contain a range of sediments depending on local relation to the ice margin (Fig. 1C). All the tributaries in the area were at least partially dammed by aggrading outwash on the Wisconsin River, thus forming small slack water lakes in the valleys (Clayton and Attig, 1997). The headwaters of some of these tributary valleys were also glaciated, creating more complicated interplay between slack water and proglacial sedimentation (Carson et al., 2012a). This includes the informally named "Swamplovers" site and Halfway Prairie Creek (Fig. 2B).

Black Earth Creek is one such westward-flowing tributary of the Wisconsin River (Fig. 1C). Black Earth Creek valley is filled with $30 \mathrm{~m}$ or more of outwash that emanated from its glaciated headwaters. As documented in Carson et al. (2012a), ice of the GBL advanced into the headwaters of a few of Black Earth Creek's tributaries, including the Swamplovers site valley, only at the very maximum extent of glaciation-significantly later than when ice had advanced into Black Earth Creek. This resulted in several tributary valleys containing a stratigraphy characterized by pre-maximum slack water lacustrine sediment, overlain by outwash or till from the glacial maximum, which in turn is overlain by postmaximum slack water lacustrine sediment. In one such valley, Carson et al. (2012a) presented OSL age control from samples collected within and immediately below the maximumstage outwash and accelerator mass spectrometry (AMS) radiocarbon age control from plant macrofossils in the postglacial lacustrine sediment from the Swamplovers site. These data indicate that ice was at the maximum position at $21.4 \pm 3.3 \mathrm{ka}$ and had retreated by $17.0 \mathrm{ka}$.

\section{Methods}

\section{Field methods}

Coring was conducted with a combination of Geoprobe direct-push coring and rotosonic drilling. Geoprobe coring collects continuous $4.5-\mathrm{cm}$-diameter cores; multiple cores at an individual site were collected as needed from within an $\sim 2-\mathrm{m}$ radius to ensure sufficient sample recovery. Coring was conducted with rotosonic drilling at the two sites where deeper sampling than possible with Geoprobe coring was desired; this method collected continuous 10-cm-diameter cores. Detailed information regarding coring sites is available in the Supplementary Material. Samples for OSL dating were collected using black-coated Geoprobe core liners or by sampling from rotosonic cores using brass tubes. Cores were transported to the Wisconsin Geological and Natural History Survey's Mount Horeb Core 
Repository and Education Center in Mount Horeb, Wisconsin, where they were stored in refrigeration before sampling and description.

\section{Laboratory methods}

Grain-size analysis to show general stratigraphic relationships was conducted by laser diffraction (Miller and Schaetzl, 2012) using a Malvern Mastersizer 2000E located in the Department of Geosciences at the University of Wisconsin-Milwaukee. We used a clay/silt boundary of 8 microns to avoid problems with systematic underestimation of clay compared with pipette and hydrometer methods (Konert and Vandenberghe, 1997; Wen et al., 2002). Complete grain-size data, including sand-silt-clay distribution using both 8 micron and 2 micron division, are available in the supplementary material following the references.

OSL samples were analyzed at the Luminescence Geochronology Laboratory at the University of Nebraska-Lincoln. We used OSL dating procedures similar to those used by Attig et al. (2011) and Carson et al. (2012a) on samples of lacustrine sediment from the Baraboo Hills and Black Earth Creek areas (see Fig. 2B). Quartz grains were isolated by sieving, floatation in heavy liquid, and treatments in hydrofluoric and finally hydrochloric acid to etch quartz grains and remove feldspars. OSL measurements were made on a Risø model DA 20 TL/OSL reader equipped with a 90Sr/90Y beta source. De values were determined through the use of the SAR method (Murray and Wintle, 2000), which was run using six beta doses that included a zero dose and one repeated dose. OSL signals were measured for $40 \mathrm{~s}$ at $125^{\circ} \mathrm{C}$. Each aliquot contained approximately 150 to 250 grains, $90-150 \mu \mathrm{m}$ diameter, that were mounted to the inner $2 \mathrm{~mm}$ of the 1 -cm disk. This "small aliquot" procedure was done to limit the potential impact of partial bleaching on our samples. A preheat temperature of $220^{\circ} \mathrm{C}$ was determined using a preheat plateau test (Wintle and Murray, 2006), and a cut heat temperature of $160^{\circ} \mathrm{C}$ was used for test doses. OSL signals for natural dose, regenerative doses, and test doses were integrated using the first four channels of the shinedown after subtracting the background signal calculated from averaging the last 31 channels measured. Individual aliquots were rejected if they had measurable signals when exposed to IR diodes, recycling ratios that were $> \pm 10 \%$, or if they had De values that were greater than the highest regenerative dose. Final age estimates were based on at least 32 accepted aliquots. Environmental dose-rate estimates were determined using the concentrations of $\mathrm{K}, \mathrm{U}$, and Th as determined by high-resolution gamma spectrometry. The cosmogenic component of the dose rate was calculated using equations from Prescott and Hutton (1994), and the final dose-rate values were calculated following equations from Aitken (1998). OSL age estimates are reported with $1 \sigma$ uncertainty.

Samples for radiocarbon dating were collected from Geoprobe cores; sampling was limited to conifer needles and leaf and stem fragments from riparian species. All radiocarbon dating was conducted by Beta Analytic, Inc. Samples were rinsed in deionized water and screened to isolate plant macrofossils. Isolated samples were washed in hot $\mathrm{HCl}$ to eliminate carbonates, then washed in $\mathrm{NaOH}$ to remove secondary organic acids, and finally rinsed in $\mathrm{HCl}$ to neutralize the solution. Analysis was conducted using AMS. Radiocarbon ages were calibrated using Calib v. 7.1 (Stuiver et al., 2019). Calibrated ages are reported 
with $2 \sigma$ uncertainty and calculated median age; for clarity and brevity, the calculated median ages are used in the text.

\section{Results}

Johnstown moraine at the Devils Lake gorge (end of GBL advance dynamics)

Rotosonic cores were collected from the two locations where the Johnstown moraine crosses the Devils Lake gorge ("DLJ-1" for the core where the moraine crosses the south end of the gorge and "DLJ-2" for the core where the moraine crosses the north end of the gorge on Fig. 2A). Core DLJ-1, at the south end of the gorge, was located on the crest of the moraine. The core penetrated a total depth of $84 \mathrm{~m}$ before lack of sample retrieval terminated coring; the core did not intersect bedrock, but did penetrate to a depth $\sim 57 \mathrm{~m}$ lower than modern level of Devils Lake. The top $3 \mathrm{~m}$ of the core were medium-brown matrixsupported sand and silt with pebbles and cobbles, interpreted as till. The remaining $81 \mathrm{~m}$ of core was coarse, massive sand and gravel, interpreted as outwash. Two distinct layers of well-sorted fine sand occurred at 52-57 m depth and 77-80 m depth. Because of the sorting and grain size, we interpreted those layers to represent short-lived proglacial lakes. OSL samples were collected from the higher and lower sand layers and returned age estimates of $34.3 \pm 4.4 \mathrm{ka}$ (UNL-3674) and $45.3 \pm 6.2 \mathrm{ka}$ (UNL-3675), respectively, although the analytical data suggest those age estimates are affected by partial bleaching (Table 1). The "moraine" blocking the south end of the Devils Lake gorge likely represents a head of outwash where sand and gravel aggraded in front of the ice margin. The thin cap of till at the coring site likely represents a late advance of ice out over top of the outwash deposit before deglaciation.

Table 1. Equivalent dose, dose rate data, and OSL age estimates for Devils Lake gorge samples

\begin{tabular}{|c|c|c|c|c|c|c|c|c|c|c|c|}
\hline Field no. & $\begin{array}{l}\text { UNL } \\
\text { lab no. }\end{array}$ & $\begin{array}{l}\text { Depth } \\
(\mathrm{m})\end{array}$ & $\begin{array}{c}\mathrm{U} \\
(\mathrm{ppm})\end{array}$ & $\begin{array}{c}\text { Th } \\
(\mathrm{ppm})\end{array}$ & $\begin{array}{c}\mathrm{K}_{2} \mathrm{O} \\
(\mathrm{wt} \%)\end{array}$ & $\begin{array}{c}\text { In situ } \mathrm{H}_{2} \mathrm{O} \\
(\%)^{\mathrm{a}}\end{array}$ & $\begin{array}{l}\text { Dose rate } \\
(\mathrm{Gy} / \mathrm{ka})\end{array}$ & $\begin{array}{c}\mathrm{CAM}^{\mathrm{b}} \mathrm{De}_{\mathrm{e}}(\mathrm{Gy}) \\
\pm 1 \mathrm{SE}\end{array}$ & $\begin{array}{l}\text { Aliquots } \\
\text { (n)c }\end{array}$ & $\begin{array}{c}\text { OSL Age } \\
\mathrm{ka} \pm 1 \sigma\end{array}$ & $\begin{array}{l}\text { O.D. }{ }^{\mathrm{d}} \\
\%\end{array}$ \\
\hline CG3-1 & UNL-3588 & 6.6 & 3.8 & 7.7 & 1.9 & 20.5 & $2.44 \pm 0.38$ & $46.9 \pm 2.1$ & $37 / 51$ & $19.2 \pm 3.2$ & 26.3 \\
\hline DLJ-1-A & UNL-3674 & 54.0 & 0.8 & 1.9 & 0.6 & 16.2 & $0.70 \pm 0.06$ & $24.1 \pm 2.1$ & $30 / 51$ & $34.3 \pm 4.4$ & 45.2 \\
\hline DLJ-1-B & UNL-3675 & 77.0 & 0.5 & 1.7 & 0.8 & 15.8 & $0.72 \pm 0.07$ & $32.7 \pm 3.0$ & $28 / 48$ & $45.3 \pm 6.2$ & 46.5 \\
\hline
\end{tabular}

aAssumes $100 \%$ error in estimated moisture content

bCentral age model (Galbraith et al., 1999)

'Accepted disks/all disks

dOverdispersion

Core DLJ-2 (Fig. 3), at the north end of the gorge, was located $200 \mathrm{~m}$ north of the crest of the moraine and in the gap cut through the moraine by the stream that drains Devils Lake. As such, the top of the core was $\sim 5.5 \mathrm{~m}$ below modern lake level and penetrated a total depth of $58 \mathrm{~m}$. The crest of the moraine is $\sim 30 \mathrm{~m}$ higher than the surface elevation of the coring site. The top $21 \mathrm{~m}$ of the core were medium-brown matrix-supported sand and silt with pebbles and cobbles (till), similar in appearance to the near-surface sediment in core DLJ-1. Visual inspection and hand trenching along the slope from coring site DLJ-2 to the crest of the moraine indicate the moraine at the surface is composed of similar sediment 
as the top $21 \mathrm{~m}$ of the core that was interpreted to be till. Beneath the till is $\sim 21 \mathrm{~m}$ of laminated silt with prominent lenses of sand, interpreted as ice-proximal lacustrine sediment. Underlying the lacustrine sediment is $\sim 8 \mathrm{~m}$ of sand and gravel, interpreted as outwash.

Taken together, the two rotosonic cores from the Devils Lake moraine indicate that ice of the GBL blocked the south end of the gorge before blocking the north end of the gorge (Fig. 3). The laminated silt in core DLJ-2 from the north end of the gorge indicates a glacial lake existed that incorporated the Devils Lake gorge and areas to the north (glacial Lake Wisconsin). Subsequent blockage of the north end of the gorge, isolated glacial-stage Devils Lake from the larger glacial Lake Wisconsin.

Figure 3 next page

Figure 3. Stratigraphy and interpretation of rotosonic cores in the Devils Lake gorge moraines. (A) Interpretive cross section in Devils Lake gorge as identified in Figure 2A, showing relationships of sediment in the gorge. (B) Core DLJ-1 from the south end of the Devils Lake gorge, showing interpreted sediments on right and grain-size data on left. OSL age estimates shown in gray italics. (C) Core DLJ-2 from the north end of the Devils Lake gorge, showing interpreted sediments on right and grain-size data on left. The colors used with the stratigraphic interpretations are also used in Figures 4 and 5. 


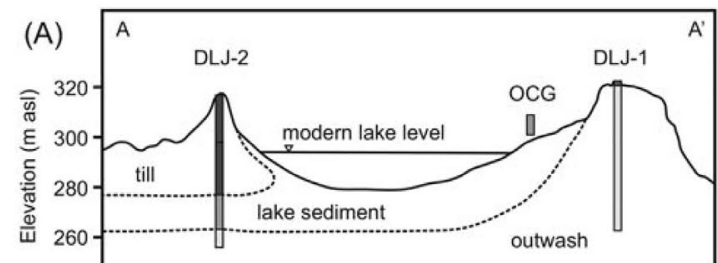

(B)

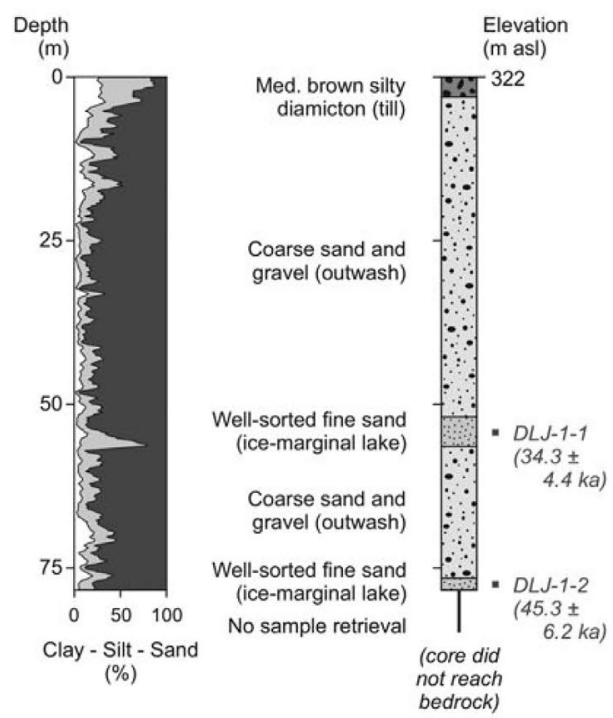

(C)

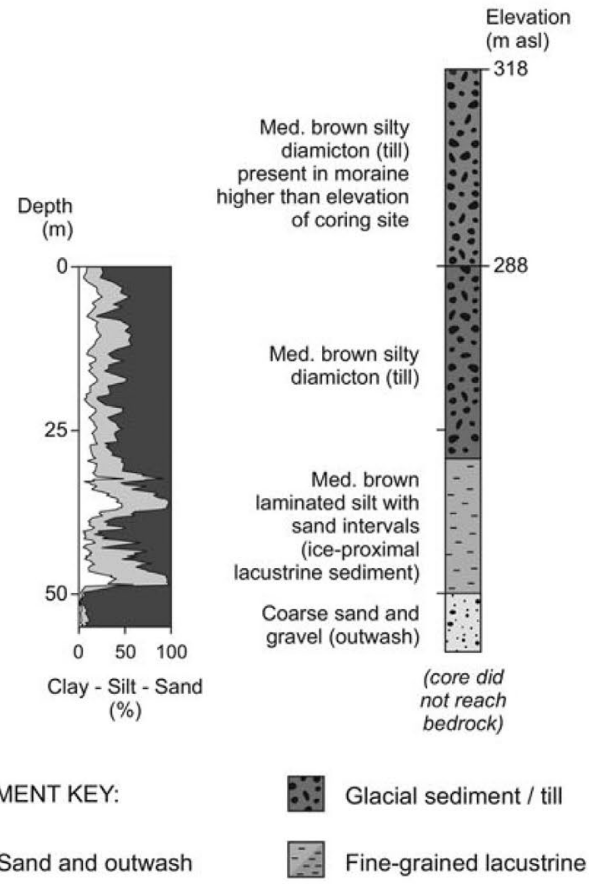

Figure 3 


\section{Benches in Devils Lake gorge (end of GBL advance chronology)}

Prominent benches of sediment with surfaces 15 to $18 \mathrm{~m}$ above the modern Devils Lake level can be found at several locations in the Devils Lake gorge. Multiple Geoprobe cores ("OCG" on Fig. 2A), were spaced within $1 \mathrm{~m}$ of each other and penetrated $8.9 \mathrm{~m}$, where the buried slope of Baraboo quartzite talus was encountered (Fig. 4). The stratigraphy from the cores consisted of $\sim 15 \mathrm{~cm}$ of weathered quartzite lying immediately on the quartzite talus, with $\sim 10 \mathrm{~cm}$ of brown cobbly sand above that. At the top of the cobbly sand is a sharp contact with a few centimeters of dark-gray sand that transitions into $\sim 1.8 \mathrm{~m}$ of darkgray laminated silty clay containing conifer needles. At $\sim 7 \mathrm{~m}$ depth, the dark-gray silty clay transitions into medium-brown laminated silt that continues to the base of the soil horizon less than $1 \mathrm{~m}$ from the surface. The surface where the core was collected is $18 \mathrm{~m}$ above the modern lake level, and the base of the core is $9.1 \mathrm{~m}$ above the modern lake level. This places the surface where the core was collected at least $9 \mathrm{~m}$ below the level of the lake at full-glacial stage as estimated by Salisbury and Atwood (1900). Because the entire core is located below the glacial stage and above the modern ( postglacial) lake level, and based on the fine-grained laminated character of the sediment, we interpret the core to represent lacustrine sedimentation during the discrete window of time when the lake was elevated due to the gorge being blocked at both ends by ice.

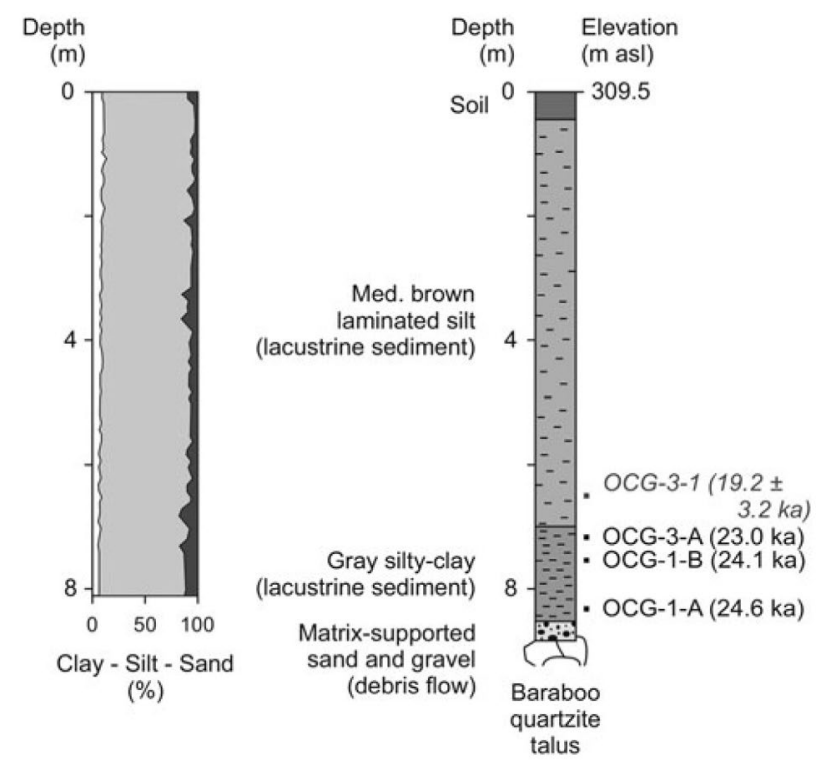

Figure 4. OCG (Old Campground) core from bench of sediment at the south end of the Devils Lake gorge, showing interpreted sediments on right and grain-size data on left. accelerator mass spectrometry (AMS) radiocarbon ages shown in black; optically stimulated luminescence (OSL) age estimates shown in gray italics.

Plant macrofossils were confined to the dark-gray silty clay near the base of the core. A conifer needle from the base of that layer yielded an age of $24.7 \mathrm{cal} \mathrm{ka} \mathrm{BP} \mathrm{(Beta-324034),}$ and conifer needles from higher in the same unit yielded ages of 24.2 cal ka BP (Beta- 
324035) and $23.0 \mathrm{cal} \mathrm{ka} \mathrm{BP} \mathrm{(Beta-322995)} \mathrm{(Table} \mathrm{2).} \mathrm{A} \mathrm{single} \mathrm{OSL} \mathrm{sample} \mathrm{from} \mathrm{the} \mathrm{laminated}$ silt immediately above the two AMS radiocarbon samples yielded an age estimate of 19.2 $\pm 3.2 \mathrm{ka}$ (UNL-3588) (Table 1). However, this age estimate coupled with the radiocarbon data from the same core does inform the time period during which the lake remained at its elevated stage. The base of this core is located $\sim 9 \mathrm{~m}$ higher than modern (postglacial) level of Devils Lake. Deposition at this site could not have started until glacial ice dammed both ends of the gorge and formed the lake at its highest stage, and continued until the end of glaciation, when the lake level dropped to its modern level due to incision through the moraine at the north end of the gorge. The basal age of $24.7 \mathrm{ka}$ can be confidently interpreted both as a closely limiting age for the timing of both ends of the gorge being blocked and Devils Lake rising to its highest (glacial) stage, and the $19.2 \pm 3.2 \mathrm{ka}$ constrains the time frame during which the lake remained at that elevated level.

Table 2. Radiocarbon dates from Baraboo Hills and Black Earth Creek areas

\begin{tabular}{|c|c|c|c|c|c|c|c|}
\hline Sample ID $^{a}$ & Material dated & Lab ID & $\begin{array}{l}\text { Depth } \\
(\mathrm{m})\end{array}$ & $\begin{array}{c}\text { Radiocarbon } \\
\text { yr BP }\end{array}$ & $\begin{array}{l}\delta^{13} \mathrm{C} \\
(\% \circ)\end{array}$ & $\begin{array}{c}\text { Calibrated } \\
\text { yr BP }(2 \sigma)^{\mathrm{b}}\end{array}$ & $\begin{array}{l}\text { Median age } \\
(\text { cal yr BP) }\end{array}$ \\
\hline SLS-12-C & Riparian leaf fragment & Beta- 407320 & 13.5 & $17,560 \pm 50$ & -26.5 & $20,990-21,440$ & 21,220 \\
\hline SLS-12-B & Riparian leaf fragment & Beta-407319 & 13.8 & $18,320 \pm 60$ & -25.9 & $21,950-22,390$ & 22,200 \\
\hline OCG-3-A & Conifer needle & Beta-322995 & 7.1 & $19,100 \pm 80$ & -26.3 & $22,740-23,350$ & 23,000 \\
\hline OCG-1-B & Conifer needle & Beta-324035 & 7.4 & $20,080 \pm 90$ & -25.7 & $23,890-24,400$ & 24,150 \\
\hline OCG-1-A & Conifer needle & Beta-324034 & 8.3 & $20,480 \pm 100$ & -26.2 & $24,310-25,040$ & 24,650 \\
\hline
\end{tabular}

aCore locations can be found in Supplementary Table 1 and Supplementary Figure 1.

bCalibrated using Calib v. 7.1 (Stuiver et al., 2019)

Wisconsin River valley and tributary sites (start of GBL retreat dynamics and chronology) On the grounds of the Badger Army Ammunition plant and immediately to the east, six Geoprobe cores were collected in a 4-km east-west transect that crossed the Johnstown moraine (Fig. 2A). Based on previous mapping (Clayton and Attig, 1990) and inspection of LIDAR-derived topography, the cores were selected so that two of them were located on the outwash plain to the west of the moraine, one of them was located on the moraine, and three of them were located on the hummocky topography east of the moraine; samples were collected to a depth of up to $12 \mathrm{~m}$. Sediment in the vicinity of the coring transect is almost exclusively medium-brown matrix-supported sand and silt with pebbles and cobbles, interpreted as till; and coarse sand and gravel, interpreted as outwash. The two western cores were entirely outwash, the two central cores were 5-6 $\mathrm{m}$ of till overlying outwash, and the two eastern cores were entirely till (Fig. 5A).

Figure 5 next page

Figure 5. (A) Description of cores (top) and interpreted local stratigraphy (bottom) for Badger Army Ammunition transect immediately to the south of the Baraboo Hills. (B) CRS core from Halfway Prairie Creek, showing interpreted sediments on right and grain-size data on left. (C) SLS core from Swamplovers site, showing interpreted sediments on right and grain-size data on left. accelerator mass spectrometry (AMS) radiocarbon ages shown in black; optically stimulated luminescence (OSL) age estimates shown in gray italics; ages with asterisks are from Carson et al. (2012a). 
(A)
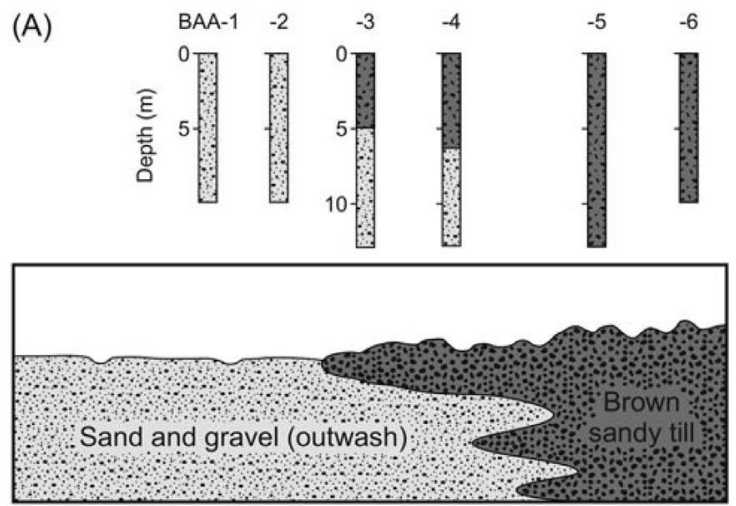

(B)
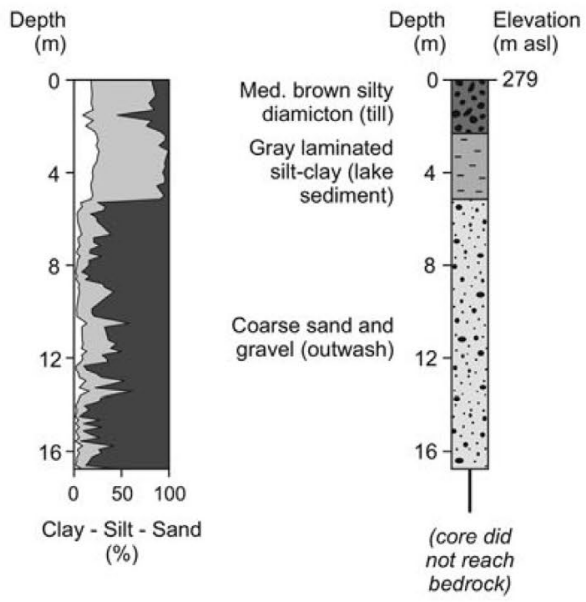

(C)

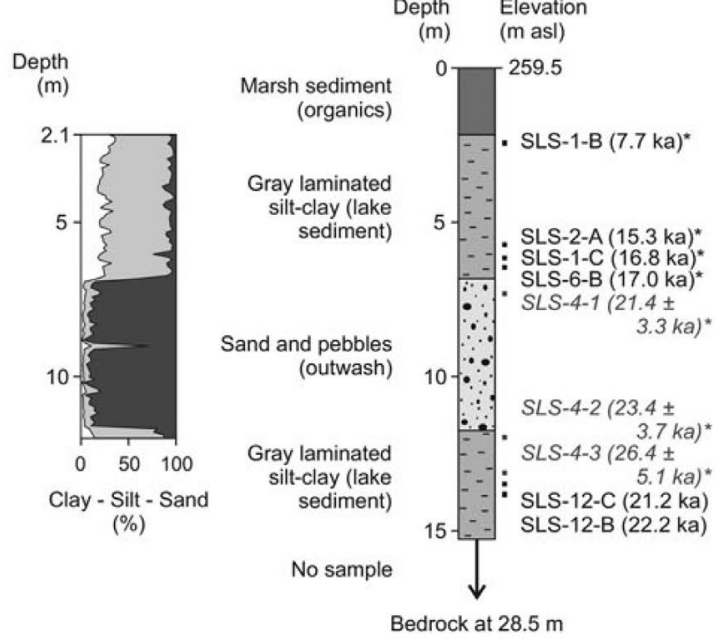

Figure 5 
Geoprobe coring in Halfway Prairie Creek ("CRS" on Fig. 2B) was located $\sim 1$ km east of the Johnstown moraine. The core penetrated through $\sim 2 \mathrm{~m}$ of matrix-supported brown silt with pebbles and cobbles, interpreted as till. Beneath the till is $\sim 3 \mathrm{~m}$ of gray laminated silty clay, interpreted as lacustrine sediment. Finally, beneath the lacustrine sediment and extending to the base of coring at $16.8 \mathrm{~m}$ was coarse sand and gravel, interpreted as outwash (Fig. 5B).

Geoprobe coring conducted at the Swamplovers site ("SLS" on Fig. 2B) retrieved gray laminated silt and clay, interpreted as lacustrine sediment, with riparian plant species from beneath the maximum-stage outwash. Two samples yielded ages of $22.2 \mathrm{ka}$ (Beta-407319) and $21.2 \mathrm{ka}$ (Beta-407320) (Fig. 5C; Table 2). These dates are in stratigraphic agreement with the existing radiocarbon dates and OSL age estimates from this site (Carson et al., 2012a). We interpret these ages to constrain the time that ice advanced into the headwaters of the Swamplovers valley, causing outwash to prograde down the valley over the premaximum lacustrine sediment.

Coring at Badger Army Ammunition plant, Halfway Prairie Creek, and Swamplovers site all indicate a similar behavior of the GBL while near its maximum position. In the immediate vicinity of all three coring sites, the geomorphology of the area suggests ice was stable at a position somewhat to the east of the local maximum before a final advance to the maximum position. At Badger Army Ammunition plant, this is documented by a hummocky ridge $\sim 3 \mathrm{~km}$ east of the Johnstown moraine and a greater amount of hummocky topography and small-scale relief east of that ridge. At Halfway Prairie Creek and Swamplovers site, this is documented by a small (several meters tall) though recognizable ridge between 2 and $3 \mathrm{~km}$ east of the Johnstown moraine. These features are all indicated on Figure 2 by white dashed lines. The stratigraphy at all three locations is similarly indicative of stability at a position east of the Johnstown moraine followed by an advance to the maximum position. This is captured, in various forms, at the three coring sites by glacial sediment (till) overlying proglacial sediment (outwash or lacustrine sediment). At the Swamplovers site, the limiting radiocarbon age of 21.2 ka shows - at least at that site-that readvance to the maximum position occurred as much as 3500 years after the ice reached near its maximum position in the Devils Lake gorge at $24.7 \mathrm{ka}$.

The stratigraphy of the DLJ-2 core at the south end of Devils Lake corroborates this interpretation. The stratigraphy of more than $75 \mathrm{~m}$ of outwash indicates that ice was at a stable position somewhere immediately to the east of the coring site for a sufficient time to deposit the volume of sand and gravel needed to form the topographic expression of the "moraine." The several meters of till, combined with the small ridge to the west of the coring site, indicate an advance of ice following deposition of the landform.

\section{Discussion}

Establishing precise geochronological control for the end of advance and the start of retreat for the GBL and nearby lobes of the Laurentide Ice Sheet has long been an elusive goal, largely resulting from the lack of datable organic material associated with MIS 2 deposits (e.g., Clayton et al., 2001; Syverson and Colgan, 2011). However, the stratigraphy revealed by coring presented here combined with the radiocarbon and OSL chronology provide the 
ability to confidently correlate ages to discrete glacial events to refine our understanding of chronology and dynamics for the end of advance and start of retreat of the GBL. The results are consistent with similar recent work along the GBL (Attig et al., 2011; Carson et al., 2012a, 2012b).

\section{Control on the end of the Green Bay Lobe's advance}

The history of the glacial lake in the Devils Lake gorge is intimately associated with the maximum position of the GBL. The occurrence of the lake required ice to dam both ends of the gorge but not overrun the central portions of the gorge or the highlands to the east and west; this was also required for Devils Lake to rise to a higher level than glacial Lake Wisconsin, as documented by Salisbury and Atwood (1900). The stratigraphy of the two rotosonic cores from the Johnstown moraine indicates that the south end of the gorge was blocked first. The available OSL ages of $34.3 \pm 4.4 \mathrm{ka}$ and $45.3 \pm 6.2 \mathrm{ka}$ provide limited information due to the small sample size and issues with potential partial bleaching. However, they do suggest the possibility that the southern GBL was nearing its maximum position significantly earlier than when it attained the Johnstown moraine position. Blockage of the north end of the gorge caused Devils Lake to rise to a level attained only while ice was at the MIS 2 maximum. Thus, the basal radiocarbon age of $24.7 \mathrm{cal} \mathrm{ka}$ BP from the lacustrine sediment in the Devils Lake gorge, supported by the stratigraphy of the two cores through the Johnstown moraine there, provides the first numeric age that can be unequivocally correlated to provide a close limiting age on the end of advance of the southern GBL.

\section{The Green Bay Lobe at and near its maximum position}

Cores from the Badger Army Ammunition plant, Halfway Prairie Creek, and Swamplovers sites all reveal a consistent stratigraphic record of a glacial advance just before widescale retreat. Combined with the geomorphology at the coring sites, the stratigraphy suggests the GBL attained a stable position near-but not at-its local maximum as marked by the Johnstown moraine. The radiocarbon chronology from the Swamplovers site indicates that this final advance occurred sometime after $21.2 \mathrm{ka}$, significantly after the GBL reached close enough to its absolute maximum to block both ends of the Devils Lake gorge at $24.7 \mathrm{ka}$.

While the data presented here do not provide insight into causation for this behavior, we suggest they may reflect local response of the ice margin in response to warming climatic conditions following the MIS 2 glacial maximum. The GBL is hypothesized to have had a frozen bed in a zone that extended several kilometers or tens of kilometers behind the margin (Attig et al., 1989). The ice margins identified in Figure 2 several miles behind the Johnstown moraine could represent stable margins under conditions when the frozen bed zone existed. Climatic warming thawed the frozen margin, increasing basal sliding stress and causing ice to thin and advance sometime after $21.2 \mathrm{ka}$. The stratigraphic data presented here document this late advance occurring at sites located $\sim 50 \mathrm{~km}$ apart along the ice front. Ullman et al. (2014) posited that fluctuations of the GBL and other lobes of the southern Laurentide Ice Sheet during this time period may have resulted from the initial rise in boreal summer insolation at 24-23 ka. While that explanation may satisfy the data presented by Ullman et al. (2014) from several different locations, it is unclear how 
the rise in insolation at this time would explain the advance of the GBL into the Swamplovers valley after $21.2 \mathrm{ka}$.

\section{Synthesis of chronologies for the southern Green Bay Lobe}

While the development of a precise numeric chronology for the GBL has been challenging, recent applications of OSL dating (e.g., Attig et al., 2011) and cosmogenic surface exposure dating (e.g., Ullman et al., 2014), combined with an emerging understanding of the importance of former iceproximal lakes as sources of datable carbon (e.g., Carson et al., 2012a, 2012b), are providing new insight into the timing of the end of the MIS 2 advance of the GBL and the onset of retreat of the GBL (Fig. 6).

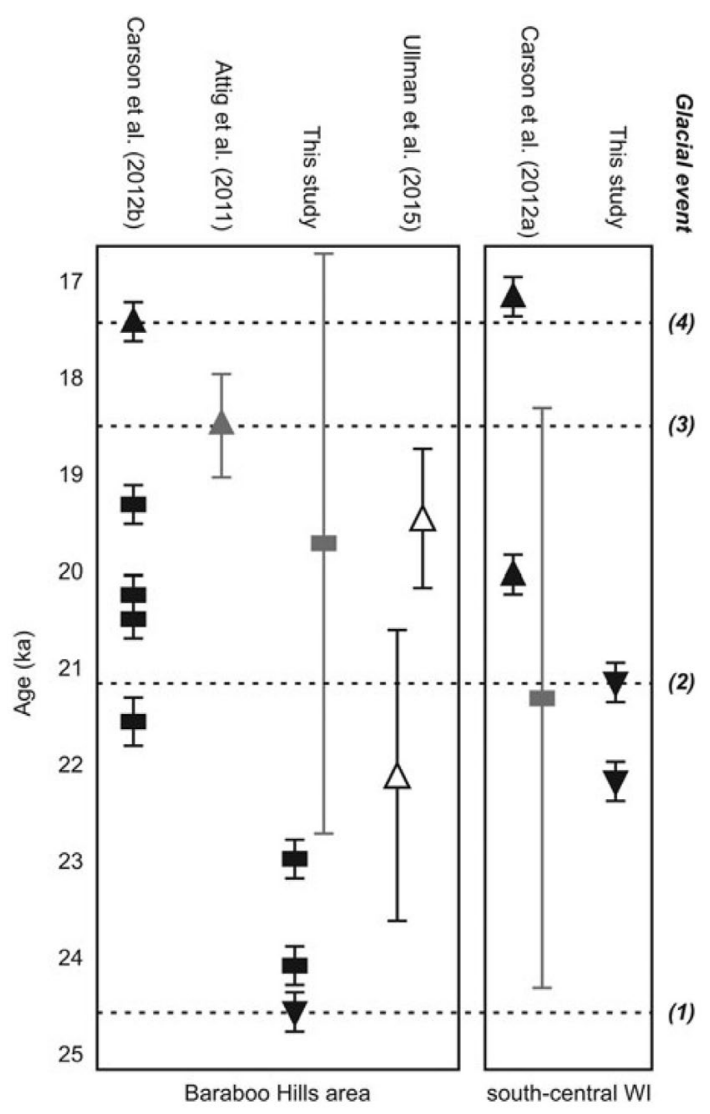

Figure 6. Correlation of absolute chronological control on glacial and lacustrine events in the vicinity of the Baraboo Hills and glacial Lake Wisconsin. Black figures represent accelerator mass spectrometry (AMS) radiocarbon ages, gray figures represent optically stimulated luminescence (OSL) dates, white-with-black-outline figures represent cosmogenic surface exposure dating (with error bars shown, as appropriate). Data from Attig et al. (2011), Carson et al. (2012a, 2012b), Ullman et al. (2014), and the present study. Arrows pointing down indicate date on end of glacial advance, rectangles represent ice margin and/or lake stability, and arrows pointing up represent indications of ice retreat or lake drainage. The four horizontal dashed lines represent the best estimates for discrete events 
in the area: (1) end of advance of the Green Bay Lobe (GBL) at the Baraboo Hills; (2) thinning and minor advance of the GBL (3) onset of retreat of the GBL from the maximum position; and (4) retreat of the GBL east of the Baraboo Hills, allowing catastrophic drainage of glacial Lake Wisconsin.

The combined suite of radiocarbon ages and OSL age estimates reported from the Devils Lake gorge area from this study, Carson et al. (2012a), and Attig et al. (2011) indicates that ice had advance to very close to its maximum position by $24.7 \mathrm{ka}$. Subsequently, as recorded in the stratigraphic record at several sites, ice advanced several kilometers sometime shortly after $21.2 \mathrm{ka}$. Ice remained close enough to its maximum position to keep the Devils Lake gorge blocked at 19.2 $\pm 3.2 \mathrm{ka}$. More regionally, Carson et al. (2012b) showed that the GBL remained at or near its maximum position in the Baraboo Hills area between $21.6 \mathrm{ka}$ and $19.3 \mathrm{ka}$. Ice began to thin and/or retreat in the Baraboo Hills area by $18.5 \mathrm{ka}$, based on the drainage of small lake basins dammed by ice on the highest points of the Baraboo Hills (Attig et al., 2011). It had begun to retreat from the Black Earth Creek area sometime before $17.0 \mathrm{ka}$ (Carson et al., 2012a) and had retreated to the eastern end of the Baraboo Hills by sometime shortly after 17.4 (Carson et al., 2012b).

Ullman et al. (2014) estimated that onset of retreat from the Devils Lake gorge area commenced by $22.1 \pm 1.5 \mathrm{ka}$, based on cosmogenic surface exposure ages of moraine boulders collected near Devils Nose (Figs. 1C and 2A). An additional age estimate by Ullman et al. (2014) from $10 \mathrm{~km}$ farther to the northeast of Devils Nose (Fig. 1C) suggests that the eastern Baraboo Hills were deglaciated by $19.4 \pm 0.7 \mathrm{ka}$. The discrepancy that exists between these cosmogenic exposure age estimates and the radiocarbon and OSL age estimates from the area could reflect a number of issues. Difficulty with interpreting ages could be introduced by local effects (e.g., topography and localized thinning of ice) rather than response of the lobe to hemispheric forcing. Similarly, responses and behavior of icemarginal positions could vary along the margin of the GBL, resulting in localized advance of ice recorded at Swamplovers site as presented here at the same time as retreat from Devils Nose suggested by Ullman et al. (2014).

\section{MIS 3 to MIS 2 advance of the Green Bay Lobe}

The data and interpretations presented here expand on the emerging record of the Laurentide Ice Sheet and the GBL from late MIS 3 to the peak of glaciation in MIS 2. Geomorphic evidence, in the form of a paucity of mapped deposits, and recent research (e.g., Dalton et al., 2016; Pico et al., 2016, 2017; Carlson et al., 2018) suggest that the LIS had a reduced extent during MIS 3 (ca. 57-29 ka). Evidence exists for fluctuations in LIS ice volumes during MIS 3 (Clark et al., 2007), yet the behavior of the GBL from late MIS 3 to the peak of MIS 2 glaciation has until recently been poorly understood. Carlson et al. (2018) documented a glacial advance of the adjacent Lake Michigan Lobe in eastern Wisconsin (Fig. 1B) at $39.0 \pm 0.4 \mathrm{ka}$ based on wood interbedded between lacustrine sediment and till. Ceperley et al. (2019) used cosmogenic exposure dating to date an advance of ice to just beyond the extent of the northern GBL to ca. $35 \mathrm{ka}$ (Fig. 1B). Here, we have documented that the southern GBL reached its MIS 2 maximum near the Devils Lake gorge at $24.7 \mathrm{ka}$. This new chronological control for the GBL, coupled with the limited OSL data from the south end of the 
Devils Lake gorge that suggests outwash was filling the southern end of the gorge by 34.3 \pm 4.4 ka to $45.3 \pm 6.2 \mathrm{ka}$, provides new insight into the advance chronology of the GBL during this period of interest.

\section{Conclusions}

The stratigraphy from cores into the Johnstown moraine at the two locations where it blocks the Devils Lake gorge in the Baraboo Hills reveals the sequence of events as the GBL reached its maximum position. Ice blocked the south end of the gorge first, forming glacial Lake Wisconsin. Sometime after that, ice blocked the north end of the Devils Lake gorge, isolating Devils Lake from the greater glacial Lake Wisconsin basin. Radiocarbon dates from a core of lacustrine sediment located in the Devils Lake gorge, and at an elevation only inundated while the lake was at its full-glacial stage, indicate that both ends of the gorge were blocked by ice sometime shortly before $24.7 \mathrm{ka}$. An OSL age estimate from the same site indicates water was at the elevated stage at the $19.2 \pm 3.2 \mathrm{ka}$ interval.

Cores from a transect on the Badger Army Ammunition site immediately to the south of the Baraboo Hills and from two sites $30 \mathrm{~km}$ farther south all contain stratigraphy consistent with ice advancing immediately before large-scale retreat. Plant macrofossils from the Swamplovers site limit this advance to having occurred sometime after $21.2 \mathrm{ka}$.

Synthesis of the available inventory of AMS radiocarbon dates and OSL age estimates from Devils Lake and southcentral Wisconsin provide a coherent, internally consistent timeline for the end of advance of the GBL and the onset of its retreat. The constraint of the end of advance of the GBL at $24.7 \mathrm{ka}$ also informs the behavior of the GBL as it advanced from a reduced MIS 3 configuration to the MIS 2 maximum.

Acknowledgments - This work was partially funded by grants from STATEMAP (G12AC20121 and G13AC00138) and the Great Lakes Geologic Mapping Coalition (G10AC00630-0001 and G12AC20388) and by the Wisconsin Geological and Natural History Survey. Field assistance was provided by B. Bates and V. Stanley. The authors would like to thank Swamplovers, LLC, and the staff of Devil's Lake State Park for land access and cooperation. The article was significantly improved by comments from D. Ullman, an anonymous reviewer, and the editorial staff at Quaternary Research.

\section{References}

Aitken, M.J., 1998. An Introduction to Optical Dating: The Dating of Quaternary Sediments by the Use of Photon-stimulated Luminescence. Oxford University Press, Oxford.

Alden, W.C., 1918. Quaternary Geology of South-Eastern Wisconsin. U.S. Geological Survey Professional Paper 106. U.S. Government Printing Office, Washington, DC.

Attig, J.W., Clayton, L., Mickelson, D.M., 1985. Correlation of late Wisconsin glacial phases in the western Great Lakes area. Geological Society of America Bulletin 96, 1585-1593.

Attig, J.W., Hanson, P.R., Rawling, J.E., III, Young, A.R., Carson, E.C., 2011. Optical ages indicate the southwestern margin of the Green Bay Lobe in Wisconsin, USA, was at its maximum extent until about 18,500 years ago. Geomorphology 130, 384-390.

Attig, J.W., Mickelson, D.M., Clayton, L., 1989. Late Wisconsin landforms and glacier-bed conditions in Wisconsin. Sedimentary Geology 62, 399-405. 
Batchelor, C.J., Orland, I.J., Marcott, S.A., Slaughter, R., Edwards, R.L., Zhang, P., Li, X., Cheng, H., 2019. Distinct permafrost conditions across the last two glacial periods in mid-latitude North America. Geophysical Research Letters 46, 13318-13326.

Carlson, A.E., Tarasov, L., Pico, T., 2018. Rapid Laurentide icesheet advance towards southern Last Glacial Maximum limit during marine isotope stage 3. Quaternary Science Reviews 196, 118-123.

Carson, E.C., Hanson, P.R., Attig, J.W., Young, A.R., 2012a. Numeric control on the late-glacial chronology of the southern Laurentide Ice Sheet derived from ice-proximal lacustrine deposits. Quaternary Research 78, 583-589.

Carson, E.C., Hanson, P.R., Attig, J.W., Young, A.R., 2012b. Refining the late glacial chronology of the Green Bay Lobe of the Laurentide Ice Sheet using ice-marginal lacustrine sediments. Geological Society of America, Abstracts with Programs 44, 454.

Ceperley, E.G., Marcott, S.A., Rawling III, J.E., Zoet, L.K., Zimmerman, S.R.H., 2019. The role of permafrost on the morphology of an MIS 3 moraine from the southern Laurentide Ice Sheet, Geology $47,440-444$.

Chamberlin, T.C., 1883. General Geology of Wisconsin. Geology of Wisconsin 1. The Commissioners of Public Printing, Madison, WI.

Clark, P.U., Hostetler, S.W., Pisias, N.G., Schmittner, A., Meissner, K.J., 2007. Mechanisms for an 7-kyr climate and sea-level oscillation during marine isotope stage 3. In: Schmittner, A., Chang, J.C.H., Hemming, S.R., (Eds.), Ocean Circulation: Mechanisms and Impacts - Past and Future Changes of Meridional Overturning. American Geophysical Union Geophysical Monographs 173. Wiley, New York, p. 209.

Clayton, L., Attig, J.W., 1989. Glacial Lake Wisconsin. Geological Society of America Memoir 173. Geological Society of America, Boulder, CO.

Clayton, L., Attig, J.W., 1990. Geology of Sauk County, Wisconsin. Wisconsin Geological and Natural History Survey Information Circular 67. Division of Extension, University of Wisconsin-Madison, Madison.

Clayton, L., Attig, J.W., 1997. Pleistocene Geology of Dane County, Wisconsin. Wisconsin Geological and Natural History Survey Bulletin 95. Division of Extension, University of Wisconsin-Madison, Madison.

Clayton, L., Attig, J.W., Mickelson, D.M., 2001. Effects of late Pleistocene permafrost on the landscapes of Wisconsin, USA. Boreas 30, 173-188.

Clayton, L., Moran, S.R., 1982, Chronology of late Wisconsinan glaciation in middle North America. Quaternary Science Reviews, 1, 55-82.

Cline, D.R., 1965. Geology and Ground-Water Resources of Dane County, Wisconsin. U.S. Geological Survey Water-Supply Paper 1779-U. U.S. Government Printing Office, Washington, DC.

Curry, B.B., Lowell, T.V., Wang, H., Anderson, A.C., 2018. Revised time-distance diagram for the Lake Michigan Lobe, Michigan Subepisode, Wisconsin Episode, Illinois, USA. In: Kehew, A.E., Curry, B.B. (Eds.), Quaternary Glaciation of the Great Lakes Region: Process, Landforms, Sediments, and Chronology. Geological Society of America Special Paper 530. Geological Society of America, Boulder, CO, pp. 69-101.

Dalton, A.S., Finkelstein, S.A., Barnett, P.J., Forman, S.L., 2016. Constraining the late Pleistocene history of the Laurentide Ice Sheet by dating the Missinaibi Formation, Hudson Bay Lowlands, Canada. Quaternary Science Reviews 146, 288-299.

Dalziel, I.W.D. and Dott, R.H., Jr., 1970. Geology of the Baraboo District, Wisconsin. Wisconsin Geological and Natural History Survey Information Circular 14. Division of Extension, University of Wisconsin-Madison, Madison. 
Heath, S.L., Loope, H.M., Curry, B.B., Lowell, T.V., 2018. Pattern of southern Laurentide Ice Sheet margin position changes during Heinrich Stadials 2 and 1. Quaternary Science Reviews 201, 362-379.

Galbraith, R.F., Roberts, R.G., Laslett, G.M., Yoshida, H., Olley, J.M., 1999, Optical dating of single and multiple grains of quartz from Jimmium rock shelter, northern Australia Part I, experimental design and statistical models. Archaeometry, 41, 339-364.

King, G.E., Robinson, R.A.J., Finch, A.A., 2014. Towards successful OSL sampling strategies in glacial environments; deciphering the influence of depositional processes on bleaching of modern glacial sediments from Jostedalen, southern Norway. Quaternary Science Reviews 89, 94-107.

Knox, J.C., 2019. Geology of the Driftless Area. In: Carson, E.C., Rawling, J.E., III, Daniels, J.M., Attig, J.W. (Eds.), The Physical Geography and Geology of the Driftless Area: The Career and Contributions of James C. Knox. Geological Society of America Special Paper 543. Geological Society of America, Boulder, CO, pp. 1-35.

Konert, M., Vandenberghe, J., 1997. Comparison of laser grain size analysis with pipette and sieve analysis: a solution for the underestimation of the clay fraction. Sedimentology 44, 523-535.

Lundqvist, J., Clayton, L., Mickelson, D.M., 1993. Deposition of the late Wisconsin Johnstown moraine, south-central Wisconsin. Quaternary International 18, 53-59.

Maher Jr., L.J., Mickelson, D.M., 1996, Palynological and radiocarbon evidence for deglaciation events in the Green Bay Lobe, Wisconsin. Quaternary Research, 46, 119-135.

Martin, L.M., 1932. The Physical Geography of Wisconsin. Wisconsin Geological and Natural History Survey Bulletin 36. University of Wisconsin Press, Madison.

Medaris, L.G., Jr., Singer, B.S., Dott, R.H., Jr., Naymark, A., Johnson, C.M., Schott, R.C., 2003. Late Paleoproterozoic climate, tectonics, and metamorphism in the southern Lake Superior Region and protoNorth America: evidence from the Baraboo interval quartzites. Journal of Geology 111, 243-257.

Mickelson, D.M., Knox, J.C., Clayton, L., 1982. Glaciation of the Driftless Area: an evaluation of the evidence. Wisconsin Geological and Natural History Survey Field Trip Guidebook 5, 155-170.

Miller, B.A., Schaetzl, R.J., 2012. Precision of soil particle size analysis using laser diffractometry. Soil Science Society of America Journal 76, 1719-1727.

Murray, A.S., Wintle, A.G., 2000. Luminescence dating of quartz using an improved single-aliquot regenerative-dose protocol. Radiation Measurements 32, 57-73.

Olcott, P.G., 1972. Bedrock Topography of Dane County. Wisconsin Geological and Natural History Survey Open-File Report 72-3, Scale 1:62,500. Division of Extension, University of Wisconsin-Madison, Madison.

Pico, T., Mitrovica, J.X., Ferrier, K.L., Braun, J., 2016. Global ice volume during MIS 3 inferred from a sea-level analysis of sedimentary core records in the Yellow River Delta. Quaternary Science Reviews 152, 72-79.

Pico, T., Creveling, J.R., Mitrovica, J.X., 2017. Sea-level records from the US mid-Atlantic constrain Laurentide Ice Sheet extent during marine isotope stage 3. Nature Communications 8, 15612.

Prescott, J.R., Hutton, J.T., 1994. Cosmic ray contributions to dose rates for luminescence and ESR dating: large depths and long-term time variations. Radiation Measurements, 23, 497-500.

Salisbury, R.D., Atwood, W.W., 1900. The Geography of the Region about Devils Lake and the Dalles of Wisconsin, with Some Notes on Its Surface Geology. Wisconsin Geological and Natural History Survey Bulletin 5. Division of Extension, University of Wisconsin-Madison, Madison.

Schaetzl, R.J., Lepper, K., Thomas, S.E., Grove, L., Treiber, L., Farmer, A., Fillmore, A. et al., 2017. Kame deltas provide evidence for a new glacial lake and suggest early glacial retreat from central Lower Michigan, USA. Geomorphology 280, 167-178. 
Stuiver, M., Reimer, P.J., Reimer, R.W., 2019. CALIB 7. 1 [WWW program], (accessed October 15, 2019) http://calib.org.

Syverson, K.M., Colgan, P.M., 2011. The Quaternary of Wisconsin: an updated review of stratigraphy, glacial history and landforms. In: Ehlers, J., Gibbard, P.L., Hughes, P.D. (Eds.), Quaternary Glaciations-Extent and Chronology: A Closer Look. Elsevier, Amsterdam, pp. 537-552.

Trowbridge, A.C., 1917. The history of Devils Lake, Wisconsin. Journal of Geology 25, 344-372.

Ullman, D.J., Carlson, A.E., LeGrande, A.N., Anslow, F.S., Moore, A.K., Caffee, M., Syverson, K.M., Licciardi, J.M., 2014. Southern Laurentide ice-sheet retreat synchronous with rising boreal summer insolation. Geology 43, 23-26.

Warren, G.K., 1874. Water communication between the Mississippi River and Lake Michigan: representation of surveys made in 1867-'68-'69; their object and extent; maps and diagrams constructed from measurements; tables of hydraulic data; anomalous physical features considered, and referred to a generalization of similar exhibitions elsewhere. $44^{\text {th }}$ Congress, $1^{\text {st }}$ Session, Senate Executive Document 28, Washington, DC, 60-89.

Wen, B., Aydin, A., Duzgoren-Aydin, N., 2002. A comparative study of particle size analyses by sieve-hydrometer and laser diffraction methods. Geotechnical Testing Journal 25, 434-442.

Wintle, A.G., Murray, A.S., 2006. A review of quartz optically stimulated luminescence characteristics and their relevance in singlealiquot regeneration dating protocols. Radiation Measurements 41, 369-391. 
Supplementary Data. Coring data from Black Earth Creek and Baraboo Hills area.

\begin{tabular}{lcccccc}
\hline Site Name & Core ID & $\begin{array}{c}\text { Latitude } \\
\left({ }^{\circ} \mathrm{N}\right)\end{array}$ & $\begin{array}{c}\text { Longitude } \\
\left({ }^{\circ} \mathrm{W}\right)\end{array}$ & $\begin{array}{c}\text { Depth } \\
(\mathrm{m})\end{array}$ & $\begin{array}{c}\text { Coring } \\
\text { Method }\end{array}$ & $\begin{array}{c}\text { Chronologic } \\
\text { Data }\end{array}$ \\
\hline Old Campground & OCG-1 & 43.406728 & 89.721740 & 8.9 & Geoprobe & ${ }^{14} \mathrm{C}, \mathrm{OSL}$ \\
Old Campground & OCG-3 & 43.406728 & 89.721728 & 8.8 & Geoprobe & ${ }^{14} \mathrm{C}$ \\
Devils Lake - Johnstown moraine & DL-1 & 43.408965 & 89.712039 & 84.0 & Rotosonic & OSL \\
Devils Lake - Johnstown moraine & DL-2 & 43.431841 & 89.732303 & 56.5 & Rotosonic & -- \\
Badger Army Ammunition & BAA-1 & 43.369582 & 89.744114 & 9.2 & Geoprobe & -- \\
Badger Army Ammunition & BAA-2 & 43.369298 & 89.738746 & 9.2 & Geoprobe & -- \\
Badger Army Ammunition & BAA-3 & 43.372951 & 89.729461 & 13.7 & Geoprobe & -- \\
Badger Army Ammunition & BAA-4 & 43.372898 & 89.724406 & 13.7 & Geoprobe & -- \\
Badger Army Ammunition & BAA-5 & 43.372718 & 89.710779 & 13.7 & Geoprobe & -- \\
Badger Army Ammunition & BAA-6 & 43.372866 & 89.700795 & 9.2 & Geoprobe & -- \\
Halfway Prairie Creek & CRS-3 & 43.187651 & 89.645192 & 16.8 & Geoprobe & -- \\
Swamplovers Site & SLS-1 & 43.120547 & 89.669498 & 28.5 & Geoprobe & ${ }^{14} \mathrm{C}$, OSL * \\
Swamplovers Site & SLS-12 & 43.120541 & 89.669498 & 15.2 & Geoprobe & ${ }^{14} \mathrm{C}$ \\
\hline
\end{tabular}

${ }^{*}{ }^{14} \mathrm{C}$ and OSL data presented in Carson et al. (2012a) from core SLS-1 and duplicate cores

from the same location. 

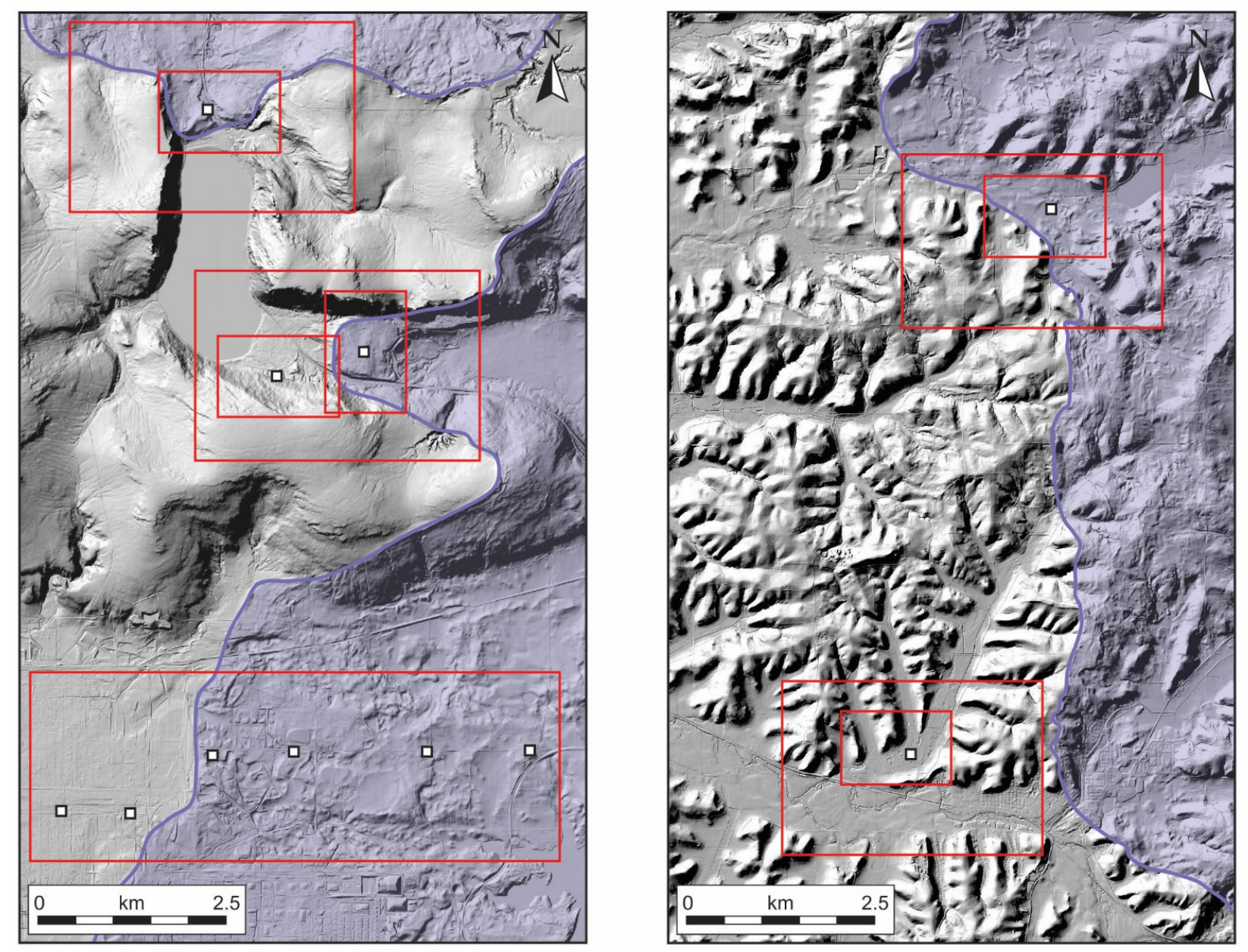

Study areas as depicted in Figure 2, showing locations of detail images of coring sites. 


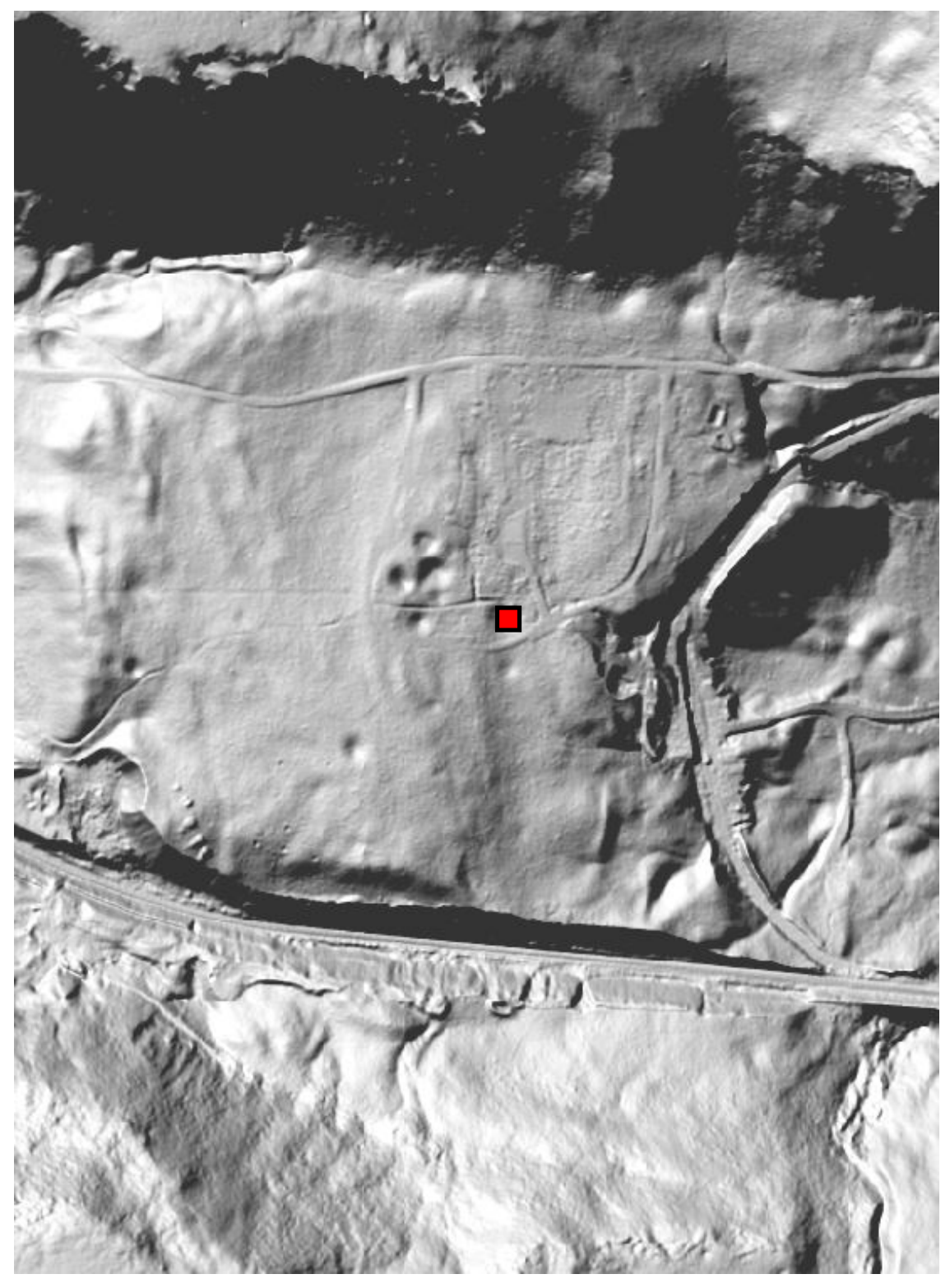

Detail of DLJ-1 coring site. 


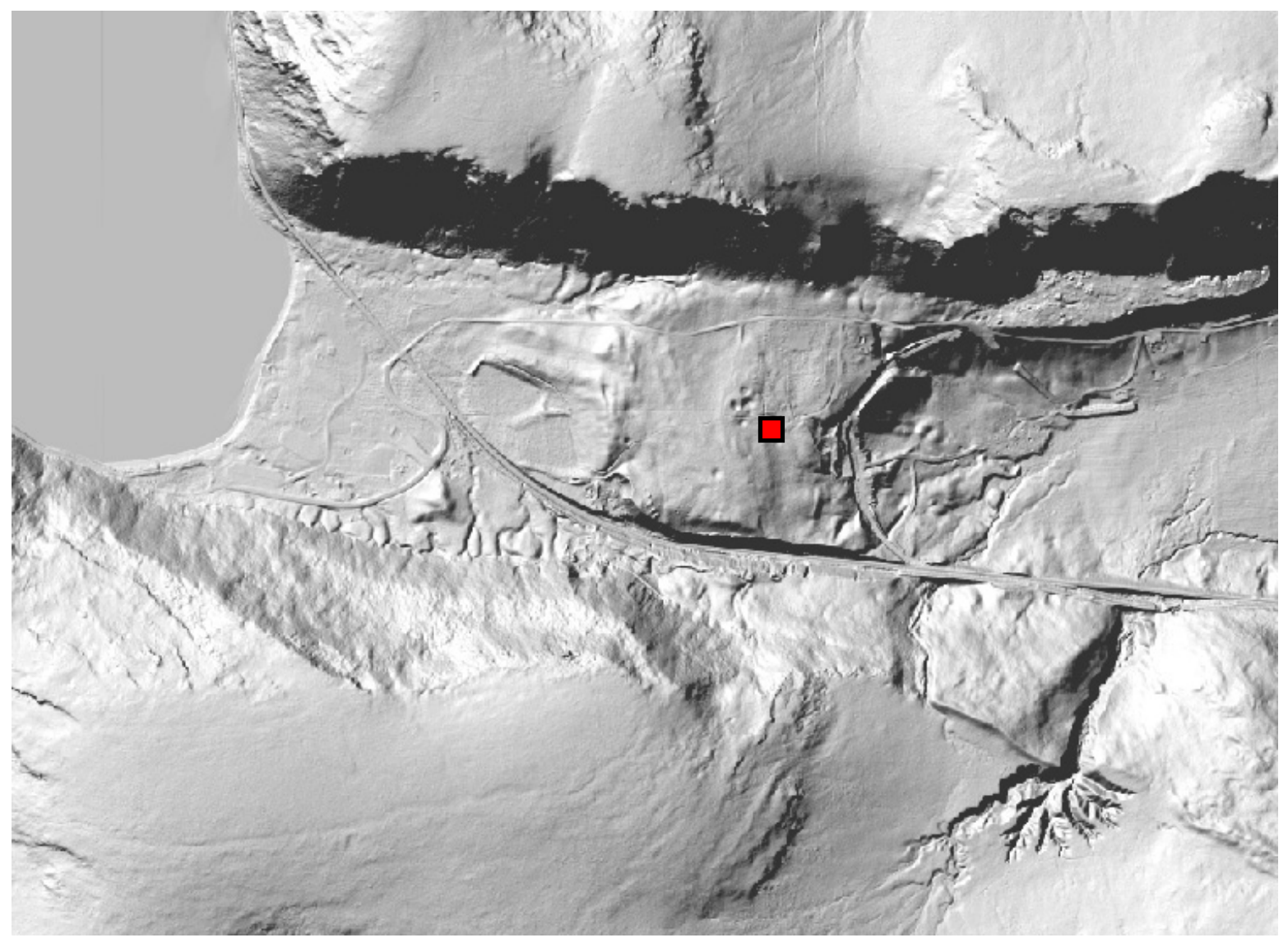

DLJ-1 coring area. 


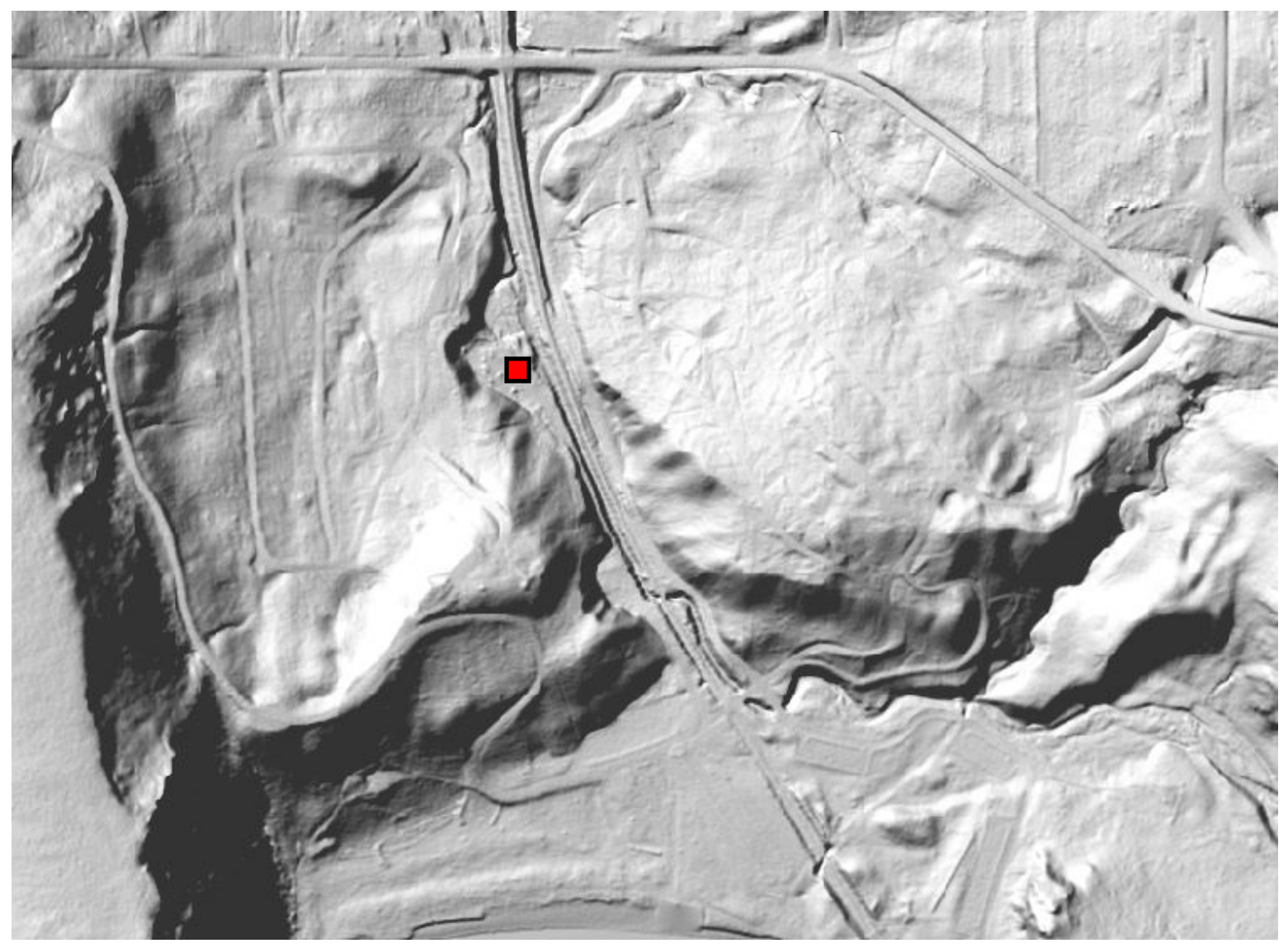

Detail of DLJ-2 coring site. 


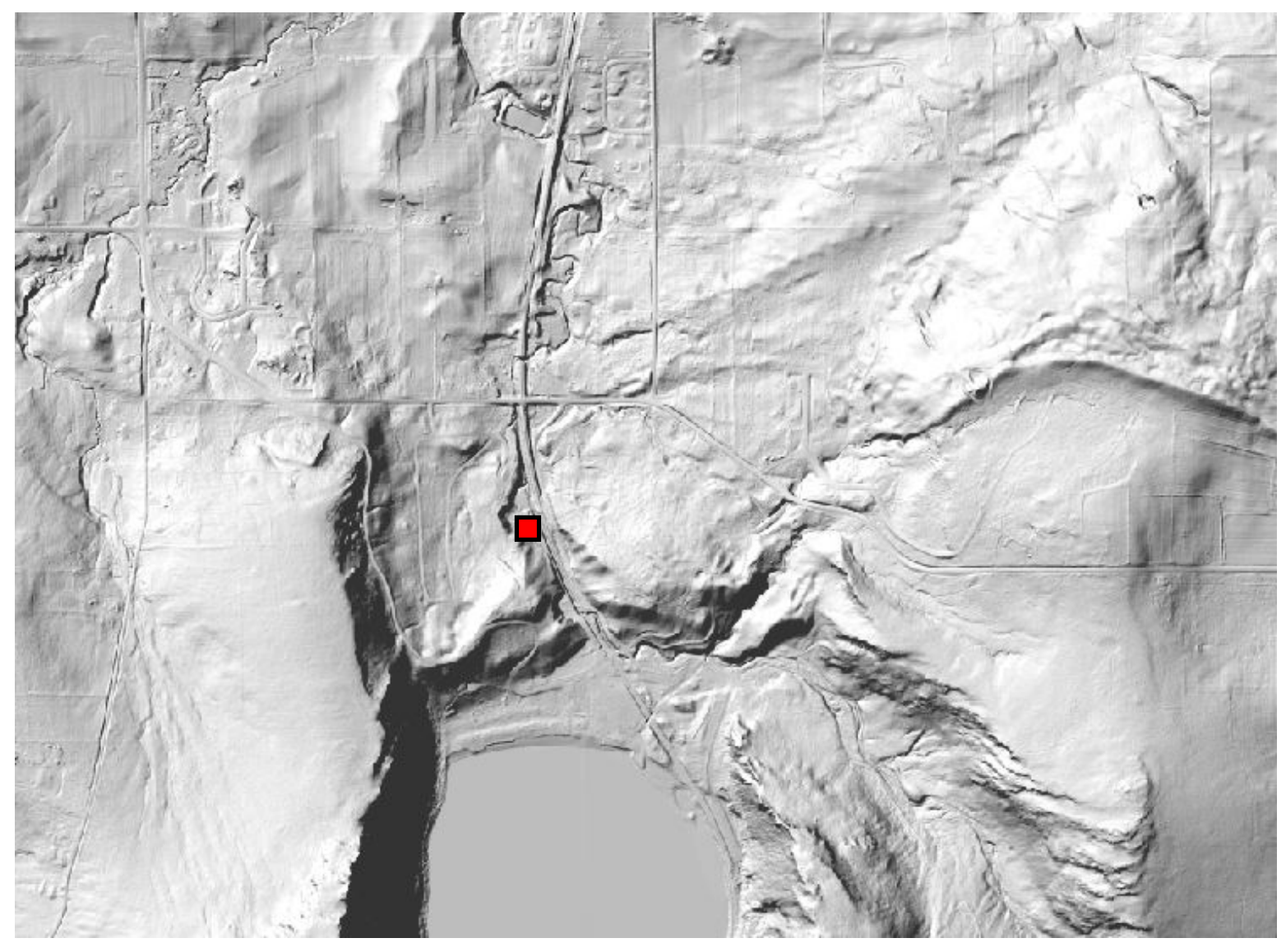

DL-2 coring area. 


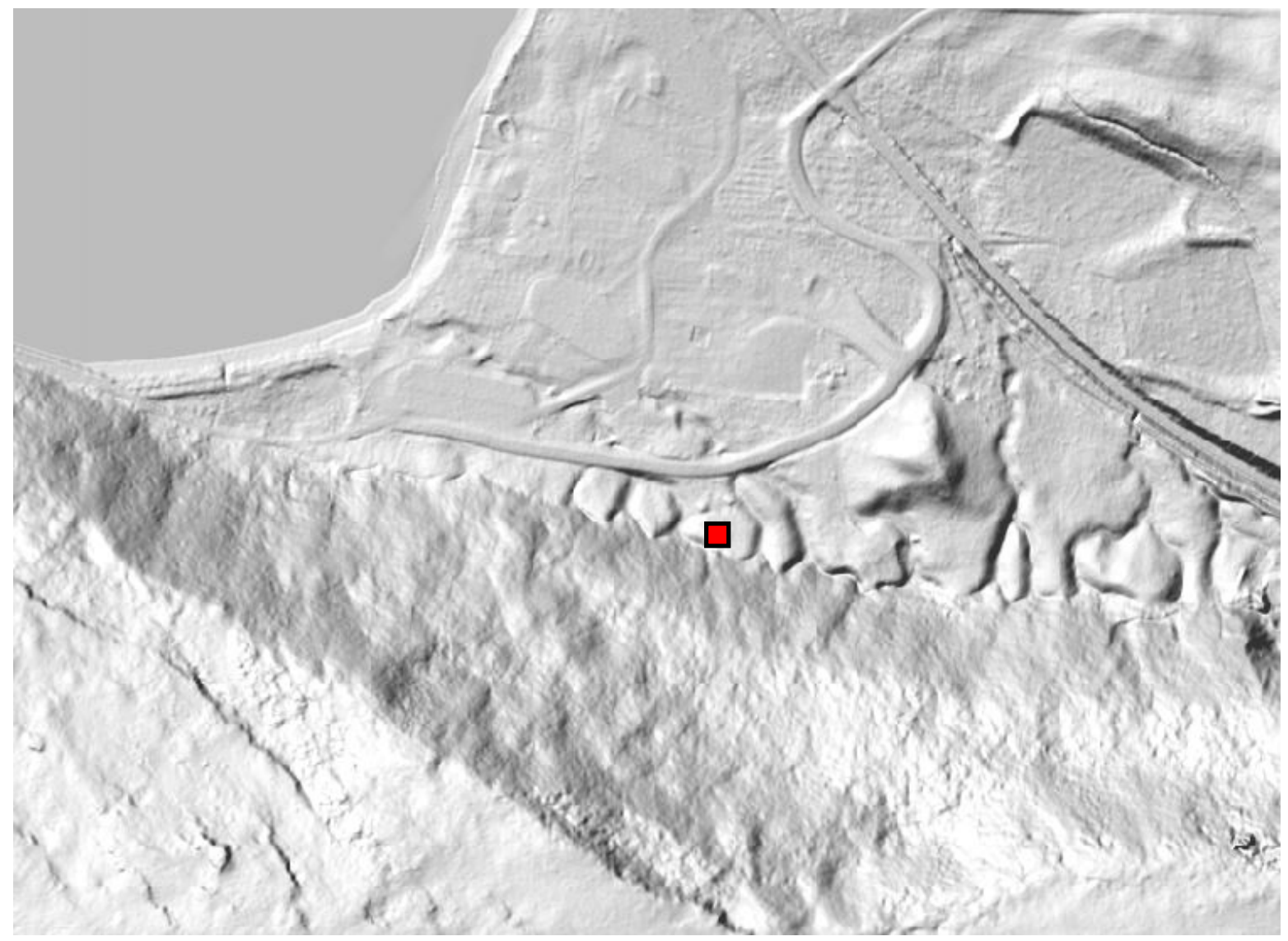

Detail of OCG coring site. 


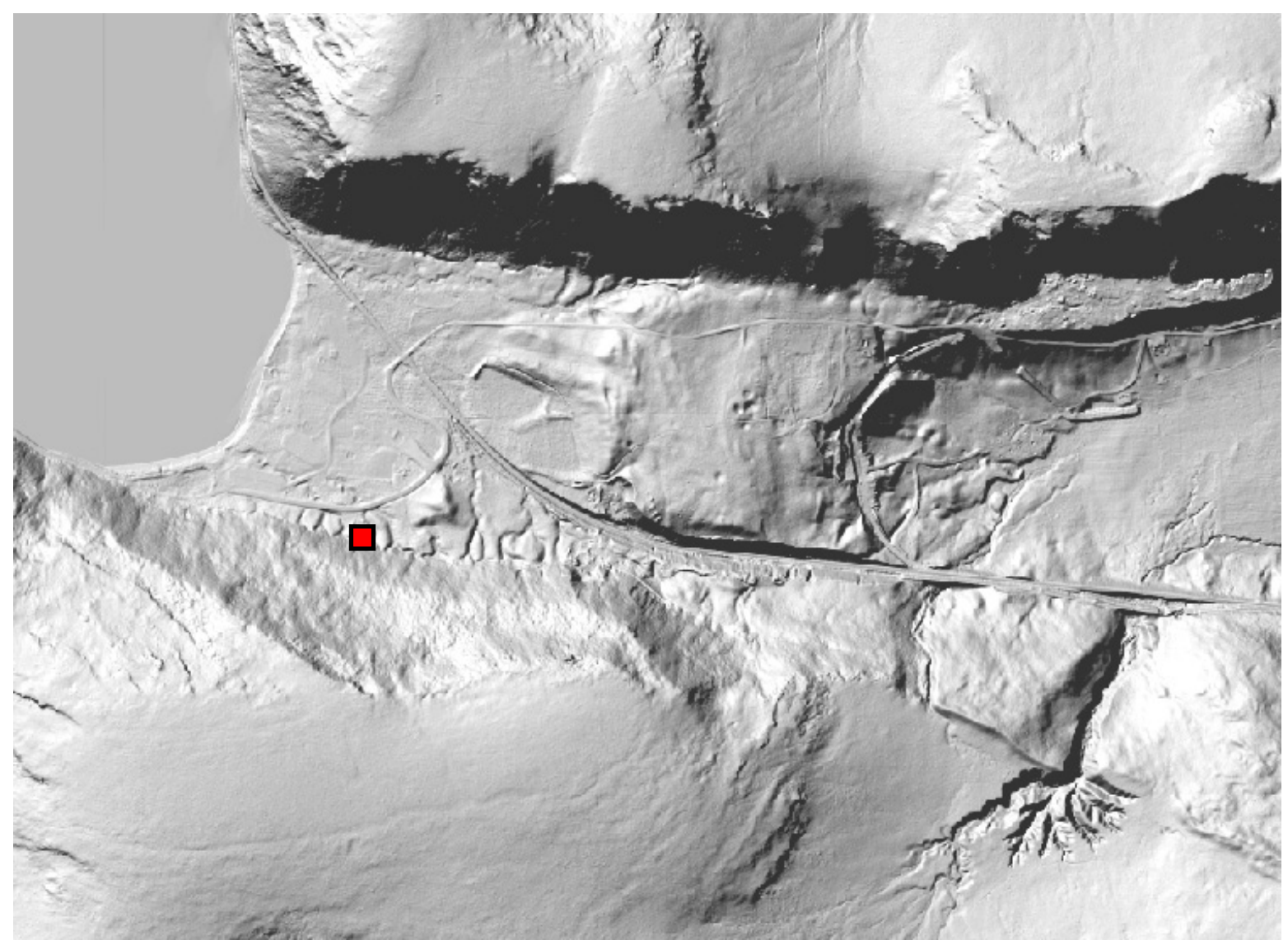

OCG coring area.

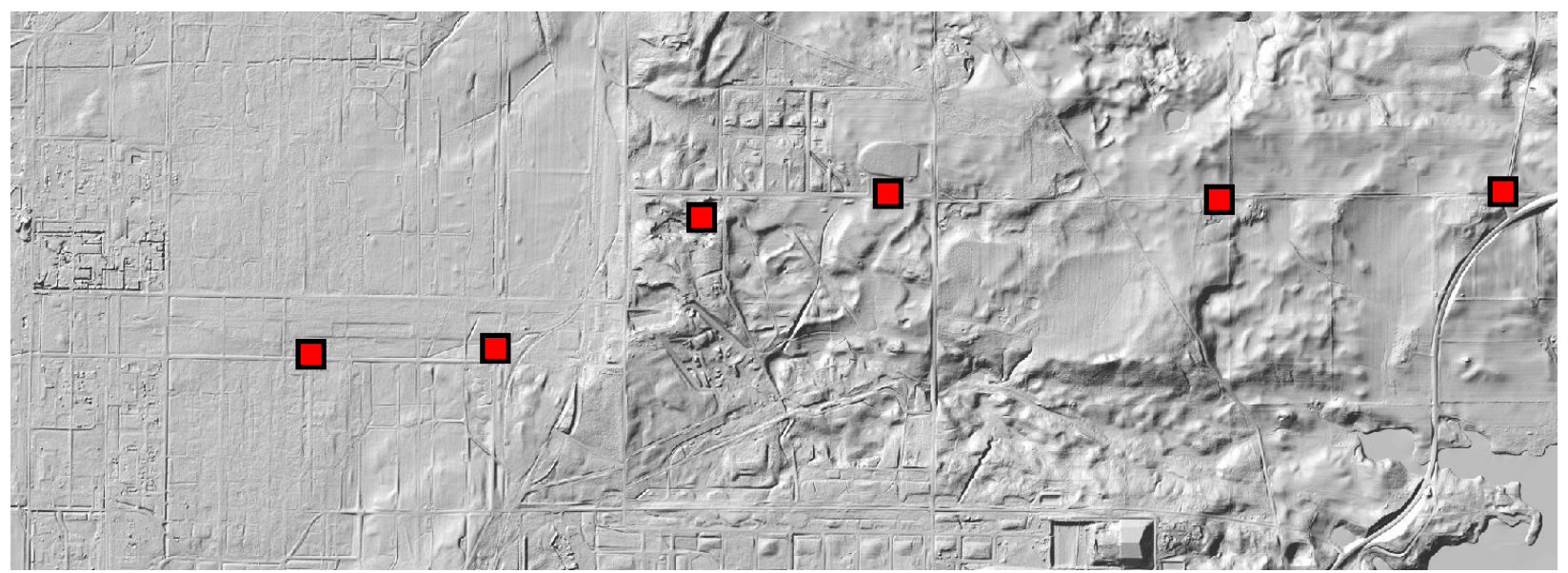

Badger Army Ammunition plant coring area. 


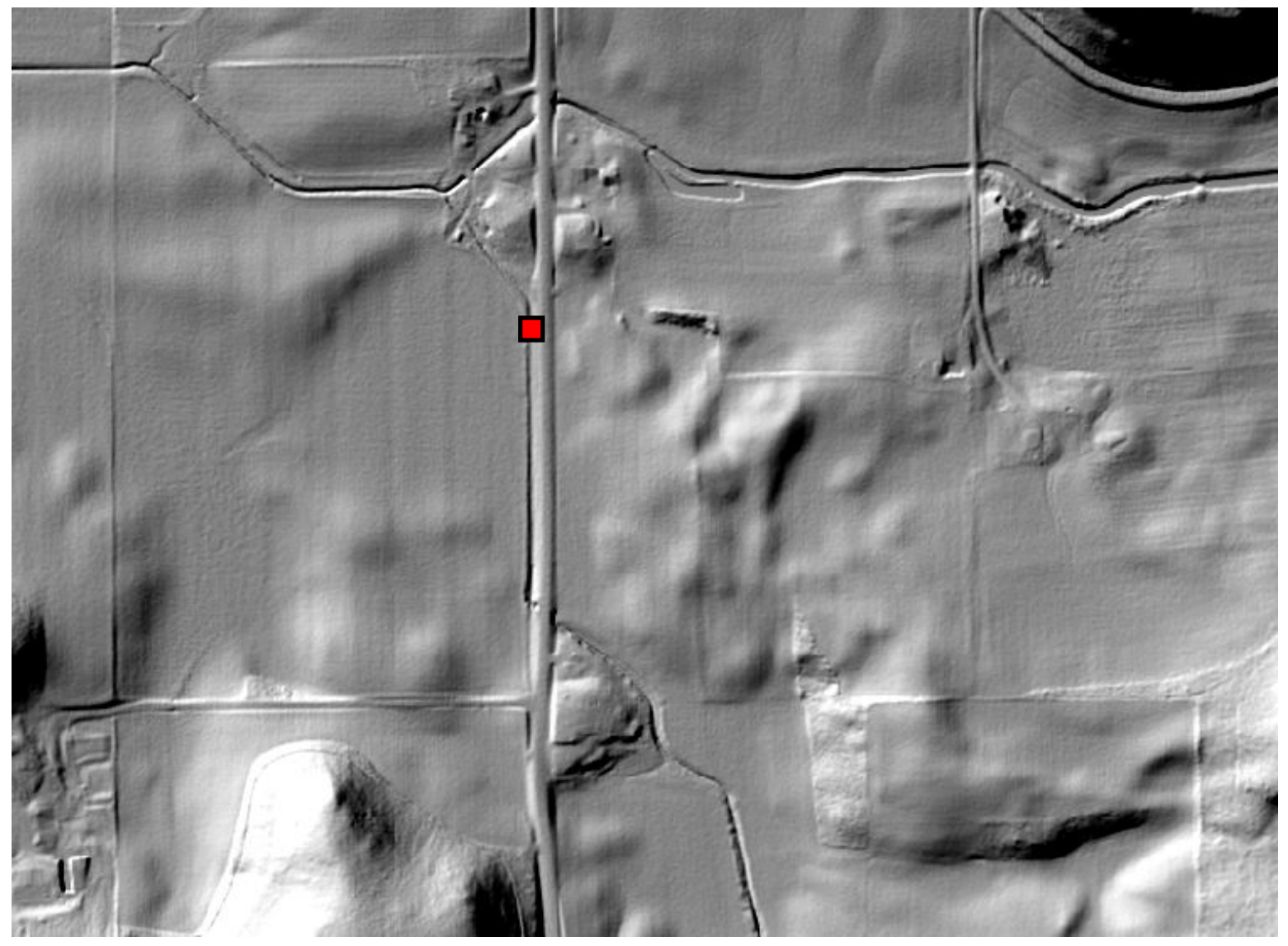

Detail of CRS coring site. 


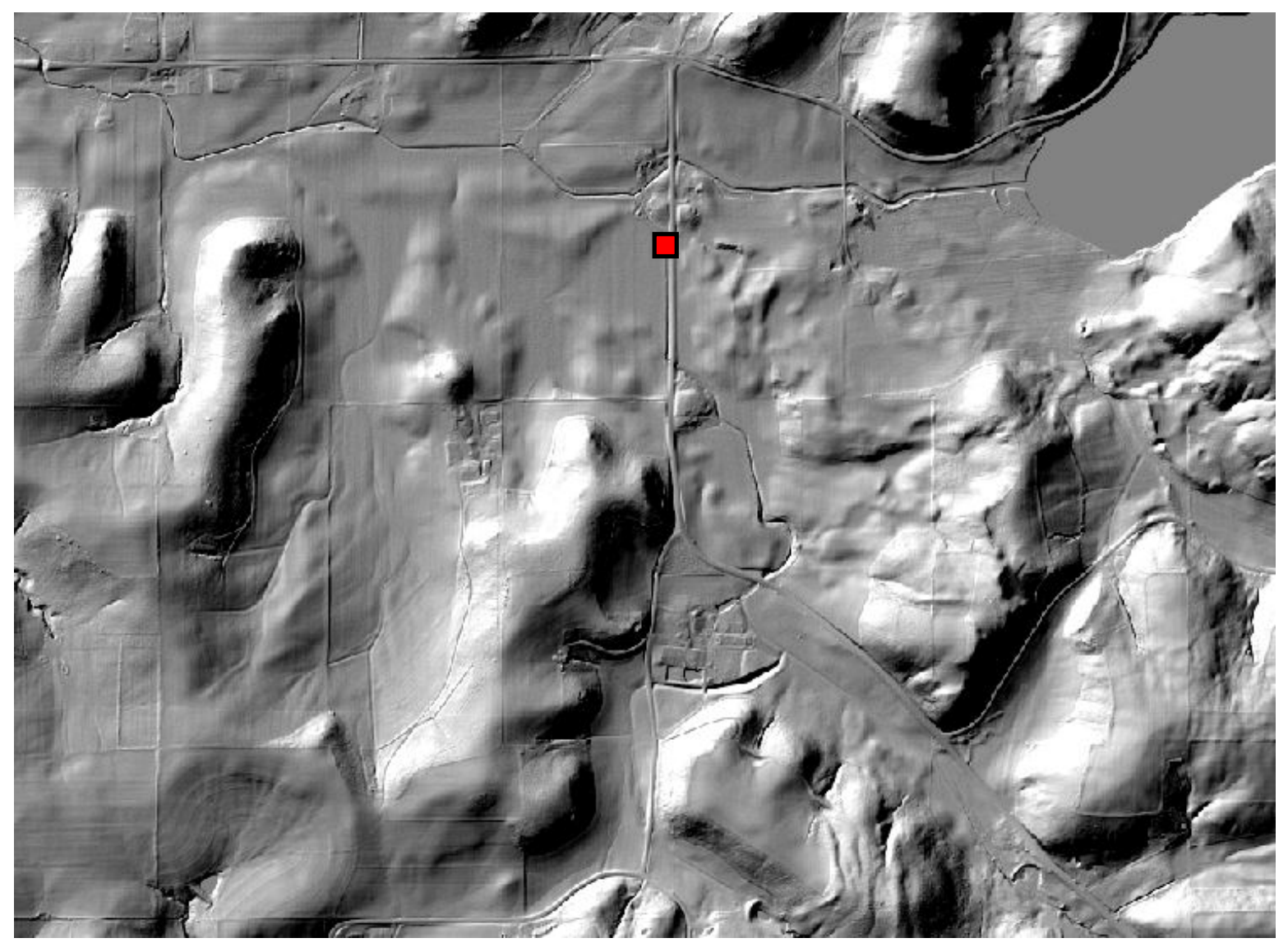

CRS coring area. 


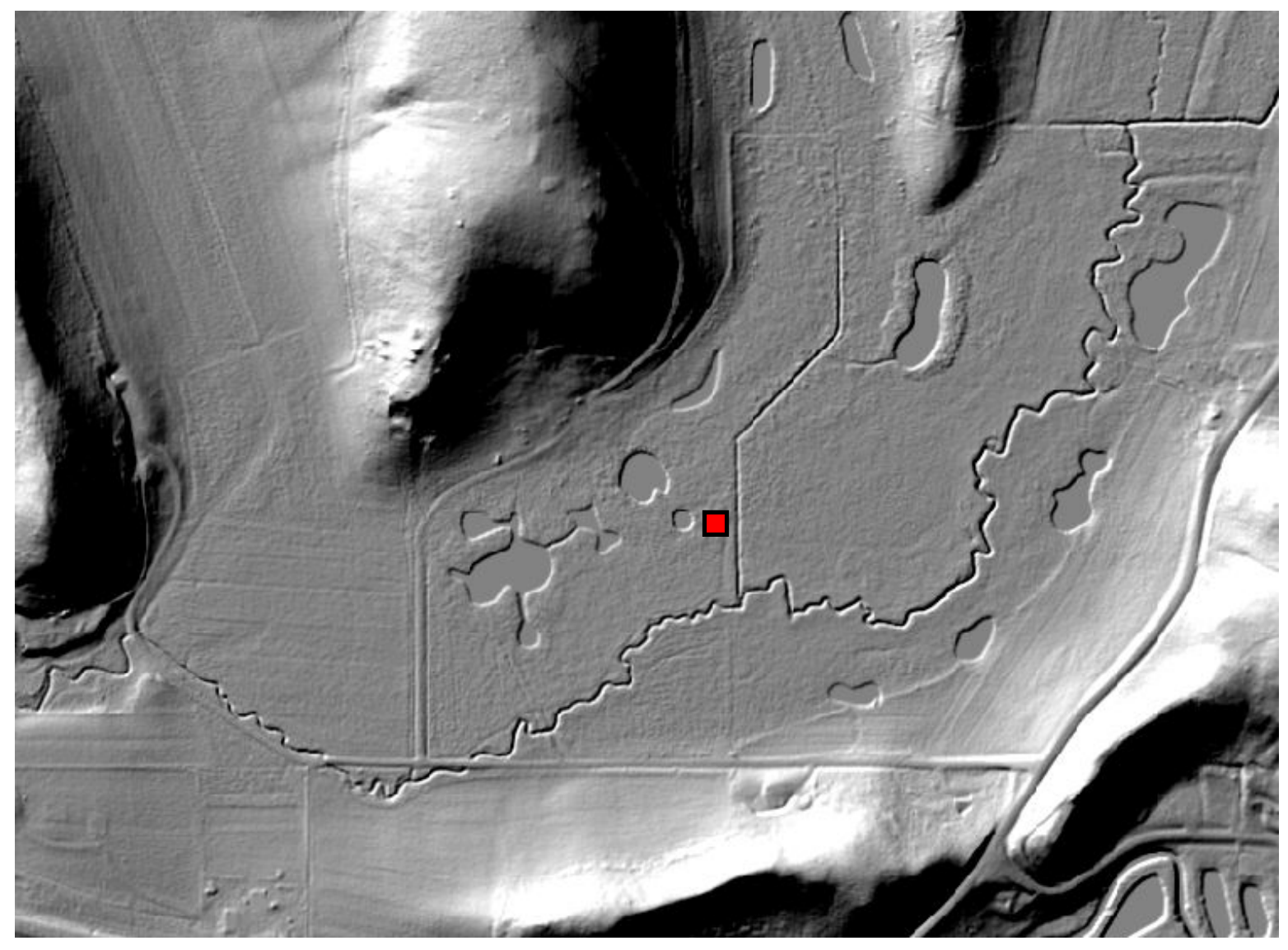

Detail of SLS coring area. 


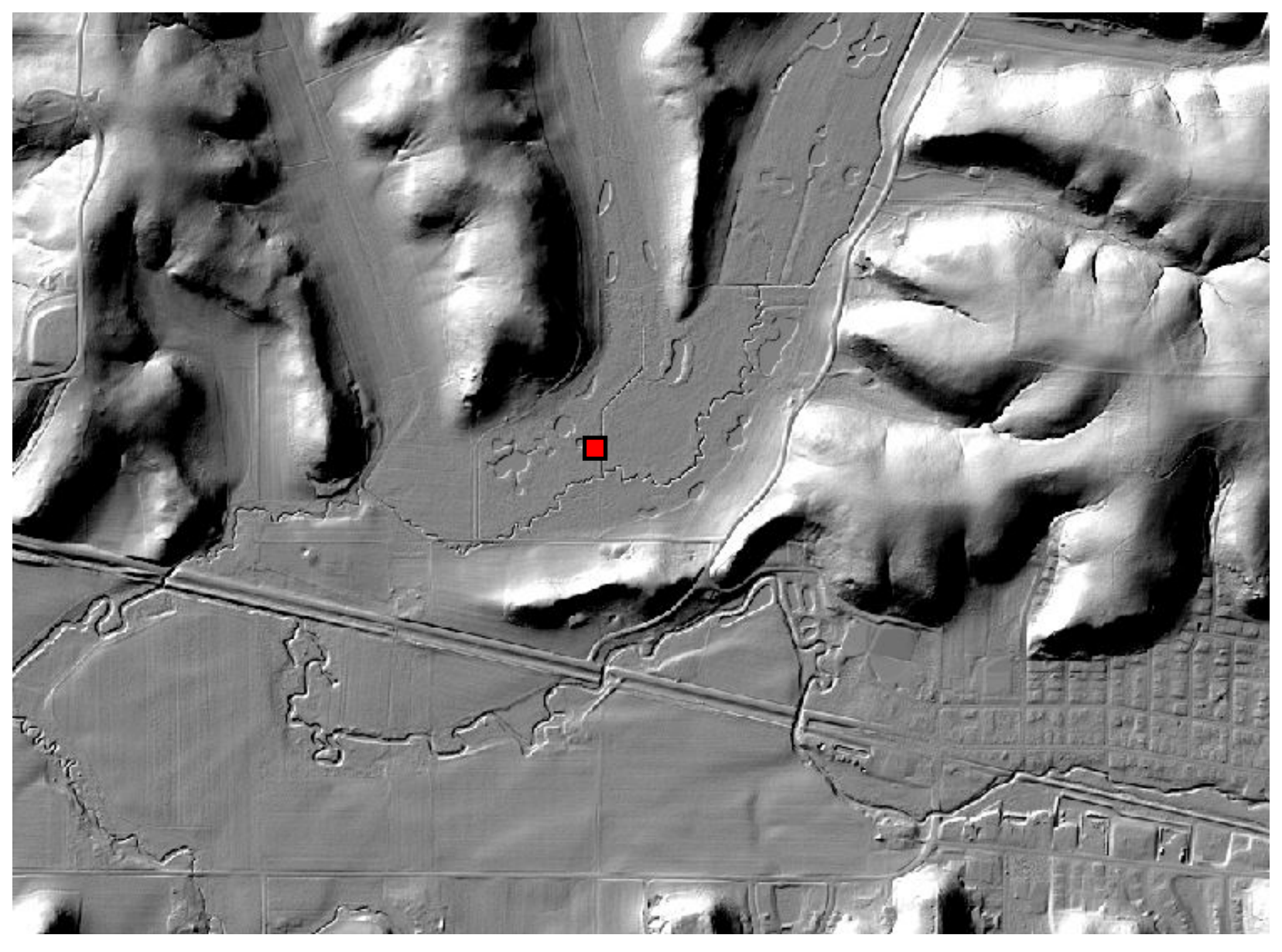

SLS coring area. 
Natural luminescence signal plot for sample UNL-3588

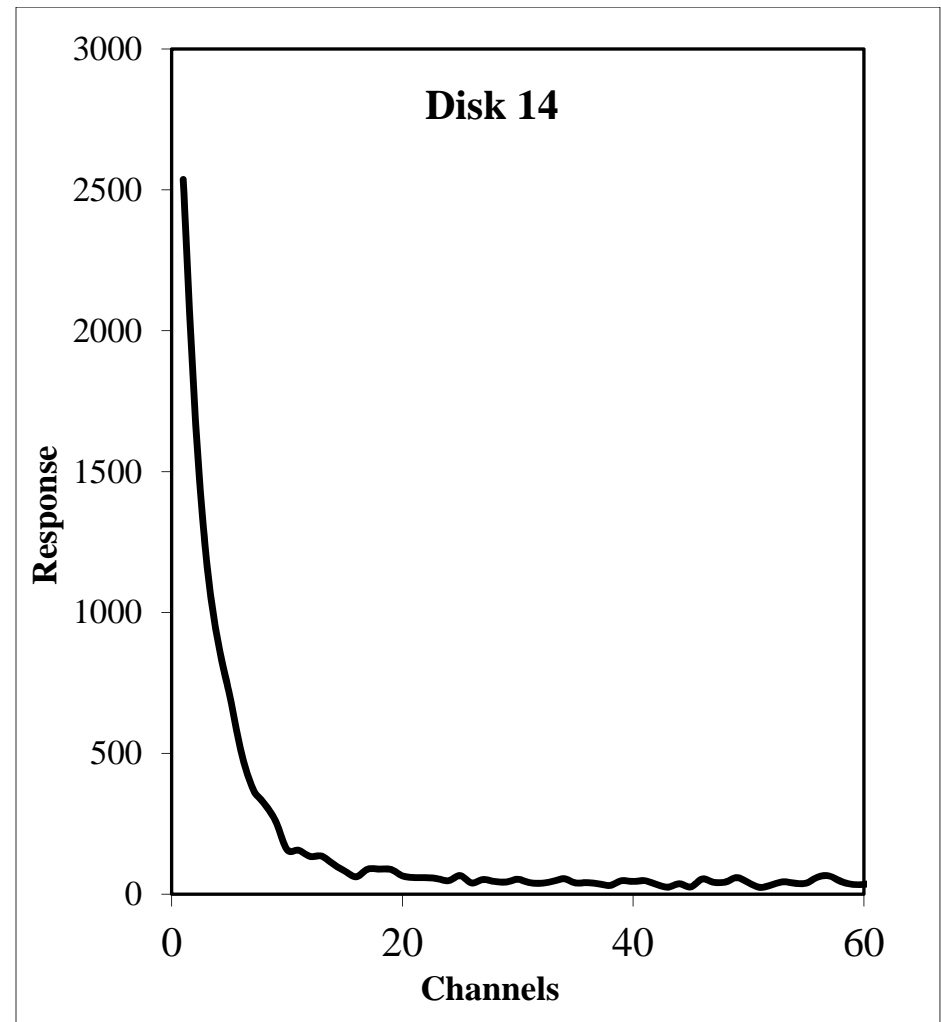

Regenerative growth curve for sample UNL-3588

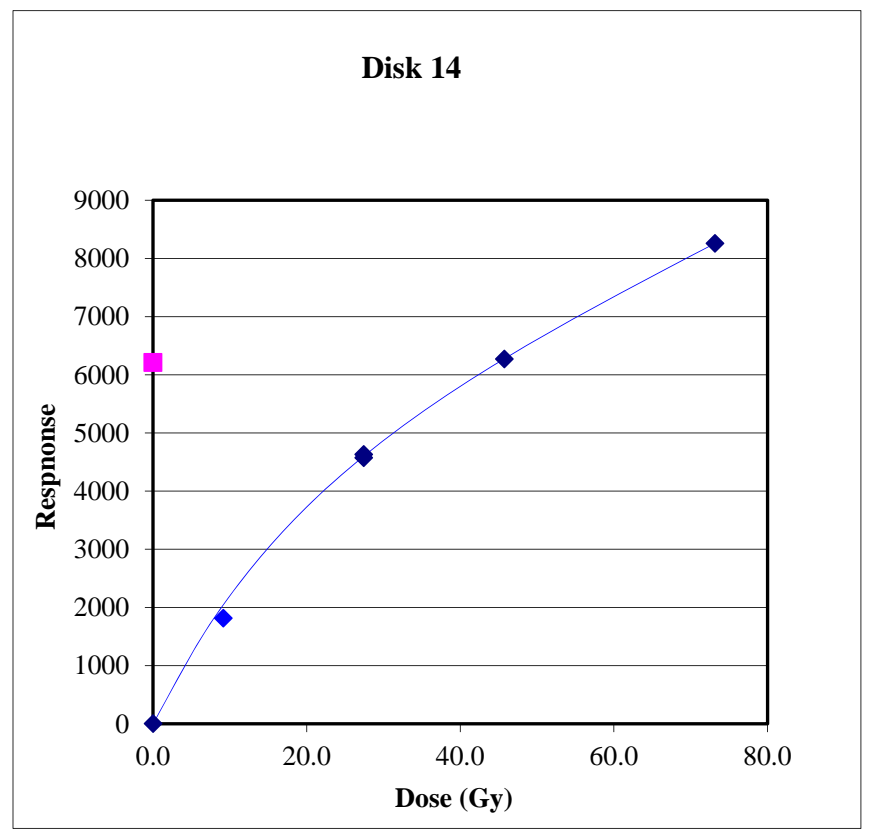


Radial plot for UNL-3588

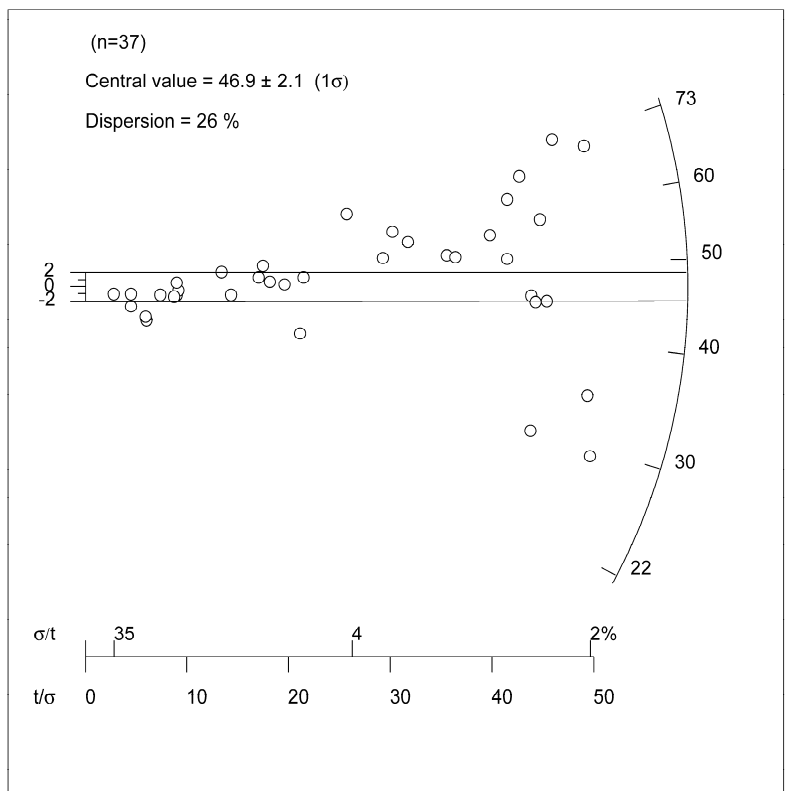

\section{Radial plot for UNL-3674}

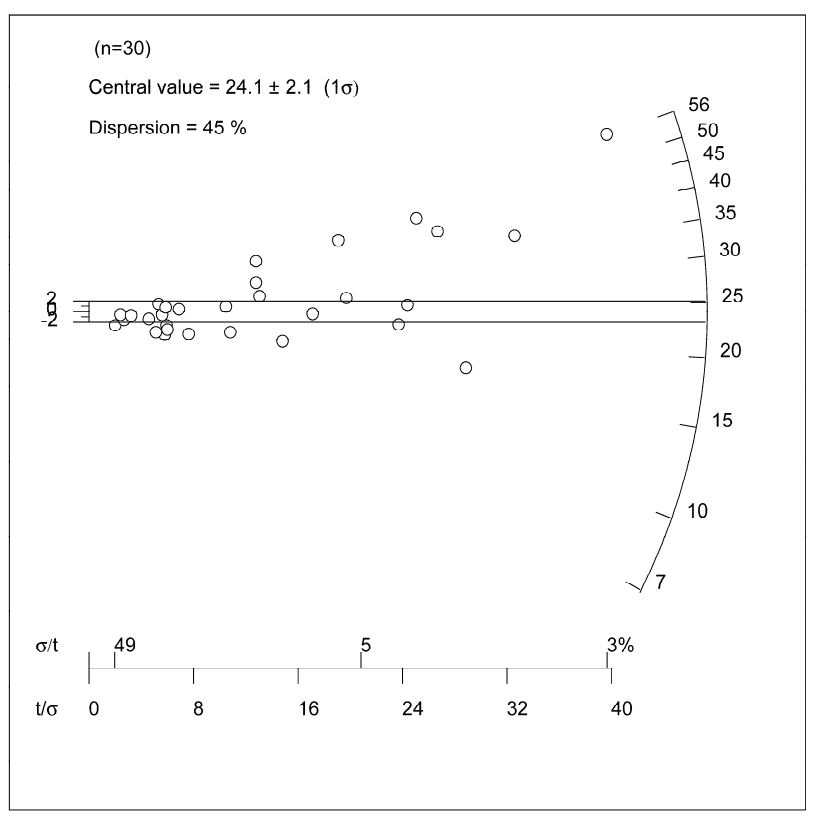


Radial plot for UNL-3675

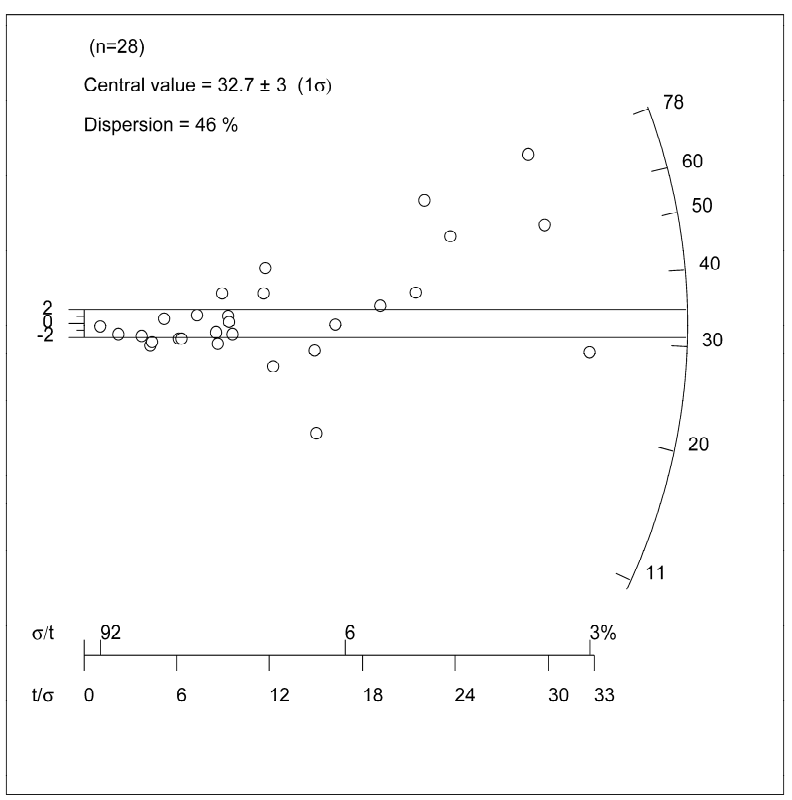


Supplementary Data. Grain-size analyses from coring sites

\begin{tabular}{|c|c|c|c|c|c|c|c|}
\hline \multirow[b]{2}{*}{ Site } & \multirow[b]{2}{*}{ Depth (cm) } & \multicolumn{3}{|c|}{ Using $2 \mu \mathrm{m}$ clay-silt divide } & \multicolumn{3}{|c|}{ Using $8 \mu \mathrm{m}$ clay-silt divide } \\
\hline & & $\begin{array}{c}\text { \% Clay } \\
(<2 \mu \mathrm{m})\end{array}$ & $\begin{array}{c}\% \text { Silt } \\
(2-63 \mu \mathrm{m})\end{array}$ & $\begin{array}{c}\text { \% Sand } \\
(>63 \mu \mathrm{m})\end{array}$ & $\begin{array}{c}\% \text { Clay } \\
\text { (<8 } \mu \mathrm{m})\end{array}$ & $\begin{array}{c}\% \text { Silt } \\
(8-63 \mu \mathrm{m})\end{array}$ & $\begin{array}{c}\text { \% Sand } \\
(>63 \mu \mathrm{m})\end{array}$ \\
\hline CRS & 69 & 1.72 & 84.13 & 14.15 & 18.97 & 66.88 & 14.15 \\
\hline CRS & 99 & 1.66 & 77.54 & 20.80 & 18.10 & 61.10 & 20.80 \\
\hline CRS & 130 & 1.79 & 82.64 & 15.57 & 19.97 & 64.46 & 15.57 \\
\hline CRS & 152 & 0.58 & 45.26 & 54.15 & 9.16 & 36.68 & 54.15 \\
\hline CRS & 175 & 1.22 & 80.48 & 18.30 & 20.38 & 61.32 & 18.30 \\
\hline CRS & 198 & 0.89 & 75.62 & 23.49 & 12.26 & 64.25 & 23.49 \\
\hline CRS & 221 & 1.53 & 88.90 & 9.57 & 21.62 & 68.81 & 9.57 \\
\hline CRS & 241 & 1.78 & 94.78 & 3.44 & 24.10 & 72.46 & 3.44 \\
\hline CRS & 262 & 2.18 & 93.58 & 4.24 & 25.20 & 70.56 & 4.24 \\
\hline CRS & 283 & 2.27 & 87.24 & 10.49 & 23.28 & 66.23 & 10.49 \\
\hline CRS & 305 & 2.60 & 96.94 & 0.46 & 26.00 & 73.55 & 0.46 \\
\hline CRS & 357 & 1.95 & 93.67 & 4.39 & 23.33 & 72.28 & 4.39 \\
\hline CRS & 375 & 1.80 & 94.37 & 3.82 & 20.49 & 75.68 & 3.82 \\
\hline CRS & 399 & 1.64 & 91.81 & 6.55 & 19.24 & 74.21 & 6.55 \\
\hline CRS & 421 & 1.77 & 94.05 & 4.18 & 19.95 & 75.87 & 4.18 \\
\hline CRS & 445 & 1.57 & 94.03 & 4.40 & 18.15 & 77.44 & 4.40 \\
\hline CRS & 457 & 1.74 & 85.52 & 12.74 & 17.85 & 69.41 & 12.74 \\
\hline CRS & 500 & 1.63 & 93.22 & 5.15 & 19.42 & 75.43 & 5.15 \\
\hline CRS & 515 & 1.64 & 89.53 & 8.83 & 18.02 & 73.15 & 8.83 \\
\hline CRS & 530 & 0.86 & 24.15 & 74.99 & 6.95 & 18.06 & 74.99 \\
\hline CRS & 549 & 0.99 & 32.16 & 66.85 & 8.51 & 24.63 & 66.85 \\
\hline CRS & 564 & 0.51 & 30.35 & 69.14 & 4.76 & 26.10 & 69.14 \\
\hline CRS & 579 & 0.30 & 17.23 & 82.47 & 3.16 & 14.36 & 82.47 \\
\hline CRS & 594 & 0.30 & 23.06 & 76.64 & 3.49 & 19.87 & 76.64 \\
\hline CRS & 610 & 0.33 & 23.88 & 75.79 & 3.78 & 20.43 & 75.79 \\
\hline CRS & 668 & 0.82 & 38.30 & 60.88 & 7.91 & 31.21 & 60.88 \\
\hline CRS & 683 & 0.43 & 20.41 & 79.16 & 4.44 & 16.40 & 79.16 \\
\hline CRS & 701 & 0.44 & 20.26 & 79.30 & 4.72 & 15.98 & 79.30 \\
\hline CRS & 716 & 0.62 & 26.93 & 72.45 & 6.26 & 21.29 & 72.45 \\
\hline CRS & 732 & 0.27 & 17.23 & 82.50 & 3.46 & 14.04 & 82.50 \\
\hline CRS & 747 & 0.18 & 16.01 & 83.81 & 2.68 & 13.52 & 83.81 \\
\hline CRS & 762 & 0.53 & 28.05 & 71.42 & 5.98 & 22.60 & 71.42 \\
\hline CRS & 780 & 0.29 & 15.33 & 84.38 & 3.52 & 12.09 & 84.38 \\
\hline CRS & 799 & 0.26 & 15.60 & 84.13 & 3.25 & 12.62 & 84.13 \\
\hline CRS & 814 & 0.23 & 12.63 & 87.14 & 2.56 & 10.29 & 87.14 \\
\hline CRS & 829 & 0.10 & 8.09 & 91.82 & 1.78 & 6.41 & 91.82 \\
\hline CRS & 846 & 0.26 & 16.37 & 83.38 & 3.21 & 13.42 & 83.38 \\
\hline CRS & 863 & 0.12 & 11.90 & 87.98 & 2.00 & 10.02 & 87.98 \\
\hline CRS & 881 & 0.46 & 29.69 & 69.84 & 5.49 & 24.66 & 69.84 \\
\hline CRS & 896 & 0.38 & 31.67 & 67.96 & 4.59 & 27.45 & 67.96 \\
\hline CRS & 914 & 0.38 & 41.50 & 58.12 & 5.56 & 36.32 & 58.12 \\
\hline CRS & 988 & 0.14 & 18.77 & 81.09 & 2.44 & 16.47 & 81.09 \\
\hline
\end{tabular}




\begin{tabular}{|c|c|c|c|c|c|c|c|}
\hline CRS & 1006 & 0.20 & 18.52 & 81.29 & 2.93 & 15.78 & 81.29 \\
\hline CRS & 1021 & 0.15 & 21.32 & 78.53 & 2.89 & 18.58 & 78.53 \\
\hline CRS & 1036 & 1.06 & 40.62 & 58.32 & 8.80 & 32.88 & 58.32 \\
\hline CRS & 1052 & 1.61 & 56.70 & 41.68 & 13.22 & 45.10 & 41.68 \\
\hline CRS & 1067 & 1.23 & 31.23 & 67.54 & 8.23 & 24.23 & 67.54 \\
\hline CRS & 1125 & 1.08 & 35.04 & 63.88 & 8.66 & 27.46 & 63.88 \\
\hline CRS & 1140 & 1.07 & 43.36 & 55.58 & 9.40 & 35.03 & 55.58 \\
\hline CRS & 1158 & 0.88 & 37.86 & 61.25 & 7.86 & 30.89 & 61.25 \\
\hline CRS & 1173 & 1.94 & 47.53 & 50.53 & 13.31 & 36.16 & 50.53 \\
\hline CRS & 1189 & 1.05 & 28.64 & 70.31 & 7.95 & 21.74 & 70.31 \\
\hline CRS & 1204 & 1.35 & 32.93 & 65.72 & 9.23 & 25.05 & 65.72 \\
\hline CRS & 1219 & 0.62 & 34.91 & 64.48 & 6.82 & 28.71 & 64.48 \\
\hline CRS & 1234 & 0.12 & 10.18 & 89.70 & 1.92 & 8.39 & 89.70 \\
\hline CRS & 1253 & 0.14 & 13.41 & 86.45 & 2.38 & 11.17 & 86.45 \\
\hline CRS & 1268 & 0.41 & 22.57 & 77.02 & 4.67 & 18.32 & 77.02 \\
\hline CRS & 1283 & 0.46 & 28.21 & 71.33 & 5.35 & 23.32 & 71.33 \\
\hline CRS & 1298 & 1.27 & 51.95 & 46.78 & 12.45 & 40.77 & 46.78 \\
\hline CRS & 1314 & 0.90 & 39.91 & 59.19 & 8.81 & 32.01 & 59.19 \\
\hline CRS & 1329 & 0.60 & 21.51 & 77.89 & 5.45 & 16.67 & 77.89 \\
\hline CRS & 1344 & 1.77 & 59.20 & 39.02 & 16.04 & 44.94 & 39.02 \\
\hline CRS & 1359 & 0.62 & 39.33 & 60.05 & 7.29 & 32.66 & 60.05 \\
\hline CRS & 1372 & 0.39 & 28.15 & 71.46 & 5.25 & 23.29 & 71.46 \\
\hline CRS & 1387 & 0.30 & 26.17 & 73.53 & 3.99 & 22.48 & 73.53 \\
\hline CRS & 1405 & 0.09 & 10.79 & 89.12 & 1.71 & 9.16 & 89.12 \\
\hline CRS & 1420 & 0.21 & 15.89 & 83.90 & 2.73 & 13.37 & 83.90 \\
\hline CRS & 1436 & 0.18 & 10.51 & 89.31 & 2.46 & 8.23 & 89.31 \\
\hline CRS & 1451 & 0.01 & 5.73 & 94.26 & 1.18 & 4.56 & 94.26 \\
\hline CRS & 1466 & 0.40 & 26.54 & 73.05 & 4.68 & 22.27 & 73.05 \\
\hline CRS & 1481 & 0.08 & 10.07 & 89.85 & 1.63 & 8.52 & 89.85 \\
\hline CRS & 1497 & 0.40 & 28.77 & 70.82 & 5.34 & 23.84 & 70.82 \\
\hline CRS & 1512 & 0.16 & 9.46 & 90.39 & 2.06 & 7.55 & 90.39 \\
\hline CRS & 1524 & 0.20 & 15.53 & 84.27 & 2.88 & 12.85 & 84.27 \\
\hline CRS & 1542 & 0.51 & 26.24 & 73.25 & 5.21 & 21.54 & 73.25 \\
\hline CRS & 1558 & 0.05 & 6.95 & 93.00 & 1.35 & 5.64 & 93.00 \\
\hline CRS & 1577 & 0.84 & 40.77 & 58.39 & 8.68 & 32.93 & 58.39 \\
\hline CRS & 1593 & 0.28 & 25.71 & 74.01 & 3.41 & 22.58 & 74.01 \\
\hline CRS & 1609 & 0.42 & 28.17 & 71.41 & 5.36 & 23.24 & 71.41 \\
\hline CRS & 1628 & 0.17 & 18.56 & 81.27 & 2.81 & 15.92 & 81.27 \\
\hline CRS & 1646 & 0.14 & 15.66 & 84.20 & 2.45 & 13.35 & 84.20 \\
\hline CRS & 1661 & 0.12 & 12.12 & 87.76 & 1.96 & 10.28 & 87.76 \\
\hline CRS & 1676 & 0.69 & 45.19 & 54.12 & 7.70 & 38.18 & 54.12 \\
\hline Dப-1 & 0 & 5.92 & 74.93 & 19.15 & 23.12 & 57.73 & 19.15 \\
\hline DU-1 & 15 & 5.30 & 67.61 & 27.09 & 20.88 & 52.03 & 27.09 \\
\hline Dப-1 & 30 & 6.31 & 82.89 & 10.80 & 25.31 & 63.88 & 10.80 \\
\hline Dப-1 & 45 & 6.80 & 78.75 & 14.46 & 26.07 & 59.48 & 14.46 \\
\hline Dப-1 & 60 & 9.25 & 78.21 & 12.53 & 29.82 & 57.64 & 12.53 \\
\hline DU-1 & 75 & 8.90 & 85.32 & 5.78 & 30.30 & 63.93 & 5.78 \\
\hline
\end{tabular}




\begin{tabular}{|c|c|c|c|c|c|c|c|}
\hline Dப-1 & 90 & 8.15 & 71.02 & 20.83 & 27.26 & 51.91 & 20.83 \\
\hline Dப-1 & 105 & 8.20 & 69.12 & 22.68 & 31.57 & 45.75 & 22.68 \\
\hline DU-1 & 120 & 9.68 & 84.57 & 5.74 & 31.91 & 62.35 & 5.74 \\
\hline DU-1 & 135 & 9.14 & 83.38 & 7.48 & 28.98 & 63.53 & 7.48 \\
\hline Dப-1 & 150 & 7.99 & 75.08 & 16.93 & 27.30 & 55.77 & 16.93 \\
\hline Dப-1 & 165 & 8.18 & 35.24 & 56.57 & 20.88 & 22.54 & 56.57 \\
\hline Dப-1 & 180 & 11.51 & 54.27 & 34.22 & 31.56 & 34.22 & 34.22 \\
\hline DU-1 & 195 & 12.18 & 62.04 & 25.78 & 33.41 & 40.81 & 25.78 \\
\hline Dப-1 & 210 & 11.11 & 44.53 & 44.36 & 30.42 & 25.22 & 44.36 \\
\hline Dப-1 & 225 & 9.91 & 68.24 & 21.86 & 30.61 & 47.53 & 21.86 \\
\hline Dப-1 & 240 & 7.58 & 44.96 & 47.45 & 22.80 & 29.74 & 47.45 \\
\hline Dப-1 & 255 & 7.64 & 49.44 & 42.92 & 24.93 & 32.14 & 42.92 \\
\hline DU-1 & 270 & 9.65 & 61.46 & 28.89 & 30.22 & 40.89 & 28.89 \\
\hline DU-1 & 285 & 8.17 & 56.89 & 34.94 & 26.67 & 38.39 & 34.94 \\
\hline DU-1 & 300 & 6.71 & 63.79 & 29.50 & 24.34 & 46.16 & 29.50 \\
\hline Dப-1 & 315 & 14.56 & 69.77 & 15.67 & 38.08 & 46.25 & 15.67 \\
\hline Dப-1 & 330 & 11.79 & 58.92 & 29.30 & 33.73 & 36.97 & 29.30 \\
\hline Dப-1 & 345 & 12.43 & 61.68 & 25.88 & 33.12 & 40.99 & 25.88 \\
\hline Dப-1 & 360 & 11.30 & 49.63 & 39.08 & 29.79 & 31.13 & 39.08 \\
\hline DU-1 & 375 & 13.40 & 59.09 & 27.51 & 34.94 & 37.55 & 27.51 \\
\hline Dப-1 & 390 & 10.28 & 54.53 & 35.19 & 28.60 & 36.21 & 35.19 \\
\hline Dப-1 & 405 & 6.85 & 38.40 & 54.75 & 19.19 & 26.06 & 54.75 \\
\hline Dப-1 & 420 & 5.13 & 34.11 & 60.76 & 14.76 & 24.48 & 60.76 \\
\hline Dப-1 & 435 & 6.57 & 39.75 & 53.68 & 18.39 & 27.92 & 53.68 \\
\hline DU-1 & 450 & 5.02 & 32.84 & 62.13 & 15.41 & 22.45 & 62.13 \\
\hline Dப-1 & 465 & 4.90 & 31.83 & 63.27 & 14.94 & 21.78 & 63.27 \\
\hline Dப-1 & 480 & 5.76 & 39.79 & 54.45 & 17.43 & 28.12 & 54.45 \\
\hline Dப-1 & 495 & 2.03 & 15.37 & 82.60 & 6.56 & 10.83 & 82.60 \\
\hline Dப-1 & 510 & 1.76 & 13.71 & 84.53 & 5.67 & 9.80 & 84.53 \\
\hline DU-1 & 525 & 9.69 & 56.45 & 33.86 & 26.94 & 39.20 & 33.86 \\
\hline DU-1 & 540 & 9.66 & 57.65 & 32.70 & 27.16 & 40.14 & 32.70 \\
\hline Dப-1 & 555 & 6.41 & 40.38 & 53.21 & 18.77 & 28.01 & 53.21 \\
\hline Dப-1 & 570 & 6.53 & 43.60 & 49.87 & 19.47 & 30.66 & 49.87 \\
\hline Dப-1 & 585 & 3.01 & 21.29 & 75.70 & 9.10 & 15.21 & 75.70 \\
\hline DU-1 & 600 & 3.21 & 21.41 & 75.39 & 9.52 & 15.09 & 75.39 \\
\hline DU-1 & 615 & 6.71 & 36.32 & 56.96 & 17.50 & 25.53 & 56.96 \\
\hline DU-1 & 630 & 6.75 & 37.80 & 55.45 & 18.69 & 25.86 & 55.45 \\
\hline Dப-1 & 645 & 5.38 & 34.56 & 60.06 & 15.65 & 24.29 & 60.06 \\
\hline Dப-1 & 660 & 4.72 & 30.03 & 65.25 & 13.87 & 20.88 & 65.25 \\
\hline Dப-1 & 675 & 1.69 & 11.23 & 87.08 & 5.20 & 7.72 & 87.08 \\
\hline DU-1 & 690 & 6.61 & 47.43 & 45.96 & 19.35 & 34.69 & 45.96 \\
\hline DU-1 & 705 & 6.53 & 65.96 & 27.51 & 19.58 & 52.91 & 27.51 \\
\hline Dப-1 & 720 & 5.52 & 47.89 & 46.59 & 16.26 & 37.15 & 46.59 \\
\hline Dப-1 & 735 & 3.73 & 29.81 & 66.46 & 11.16 & 22.38 & 66.46 \\
\hline DU-1 & 750 & 3.10 & 15.42 & 81.48 & 8.69 & 9.82 & 81.48 \\
\hline DU-1 & 765 & 2.30 & 19.30 & 78.40 & 5.95 & 15.65 & 78.40 \\
\hline DU-1 & 780 & 2.86 & 21.07 & 76.07 & 8.08 & 15.84 & 76.07 \\
\hline
\end{tabular}




\begin{tabular}{|c|c|c|c|c|c|c|c|}
\hline DU-1 & 795 & 3.61 & 37.68 & 58.72 & 9.22 & 32.07 & 58.72 \\
\hline DU-1 & 810 & 2.64 & 45.73 & 51.63 & 6.73 & 41.64 & 51.63 \\
\hline Dப-1 & 825 & 1.41 & 9.48 & 89.11 & 4.16 & 6.73 & 89.11 \\
\hline Dப-1 & 840 & 2.27 & 18.07 & 79.66 & 6.92 & 13.41 & 79.66 \\
\hline Dப-1 & 855 & 0.00 & 95.98 & 4.02 & 1.48 & 94.50 & 4.02 \\
\hline DU-1 & 870 & 1.85 & 17.90 & 80.25 & 6.17 & 13.58 & 80.25 \\
\hline Dப-1 & 885 & 1.84 & 16.54 & 81.62 & 5.94 & 12.44 & 81.62 \\
\hline Dப-1 & 900 & 0.58 & 6.93 & 92.49 & 2.08 & 5.43 & 92.49 \\
\hline Dப-1 & 915 & 0.64 & 8.32 & 91.04 & 2.30 & 6.67 & 91.04 \\
\hline Dப-1 & 930 & 0.00 & 2.06 & 97.94 & 0.01 & 2.05 & 97.94 \\
\hline Dப-1 & 945 & 1.34 & 14.06 & 84.60 & 4.27 & 11.14 & 84.60 \\
\hline Dப-1 & 960 & 0.50 & 3.69 & 95.81 & 1.74 & 2.45 & 95.81 \\
\hline Dப-1 & 975 & 0.08 & 3.60 & 96.32 & 0.64 & 3.04 & 96.32 \\
\hline Dப-1 & 990 & 0.31 & 5.45 & 94.25 & 1.45 & 4.30 & 94.25 \\
\hline Dப-1 & 1005 & 5.38 & 63.31 & 31.32 & 10.63 & 58.05 & 31.32 \\
\hline Dப-1 & 1020 & 1.83 & 22.32 & 75.85 & 6.45 & 17.69 & 75.85 \\
\hline DU-1 & 1035 & 3.85 & 29.98 & 66.17 & 11.28 & 22.55 & 66.17 \\
\hline DU-1 & 1050 & 7.51 & 55.44 & 37.05 & 24.84 & 38.12 & 37.05 \\
\hline DU-1 & 1065 & 3.41 & 26.04 & 70.55 & 11.48 & 17.97 & 70.55 \\
\hline DU-1 & 1080 & 6.47 & 39.05 & 54.48 & 19.82 & 25.70 & 54.48 \\
\hline Dப-1 & 1095 & 4.25 & 25.69 & 70.05 & 12.79 & 17.16 & 70.05 \\
\hline Dப-1 & 1110 & 7.07 & 37.39 & 55.54 & 20.74 & 23.72 & 55.54 \\
\hline DU-1 & 1125 & 10.46 & 54.20 & 35.34 & 29.99 & 34.67 & 35.34 \\
\hline Dப-1 & 1140 & 5.14 & 24.59 & 70.28 & 14.02 & 15.71 & 70.28 \\
\hline DU-1 & 1155 & 10.10 & 42.26 & 47.64 & 26.42 & 25.94 & 47.64 \\
\hline Dப-1 & 1170 & 7.82 & 37.54 & 54.63 & 20.44 & 24.92 & 54.63 \\
\hline Dப-1 & 1185 & 5.75 & 36.72 & 57.53 & 14.83 & 27.64 & 57.53 \\
\hline Dப-1 & 1200 & 6.79 & 29.65 & 63.55 & 16.46 & 19.99 & 63.55 \\
\hline Dப-1 & 1215 & 10.08 & 49.69 & 40.24 & 25.01 & 34.76 & 40.24 \\
\hline Dப-1 & 1230 & 0.82 & 5.52 & 93.66 & 2.49 & 3.85 & 93.66 \\
\hline Dப-1 & 1245 & 3.29 & 19.78 & 76.93 & 8.74 & 14.33 & 76.93 \\
\hline Dப-1 & 1260 & 2.32 & 14.31 & 83.37 & 6.11 & 10.52 & 83.37 \\
\hline Dப-1 & 1275 & 2.87 & 14.41 & 82.71 & 7.50 & 9.79 & 82.71 \\
\hline DU-1 & 1290 & 3.37 & 17.23 & 79.40 & 8.60 & 11.99 & 79.40 \\
\hline DU-1 & 1305 & 1.63 & 8.67 & 89.70 & 4.41 & 5.88 & 89.70 \\
\hline Dப-1 & 1320 & 1.92 & 11.34 & 86.74 & 5.13 & 8.12 & 86.74 \\
\hline Dப-1 & 1335 & 5.91 & 34.86 & 59.23 & 15.14 & 25.63 & 59.23 \\
\hline Dப-1 & 1350 & 4.42 & 41.71 & 53.88 & 17.35 & 28.77 & 53.88 \\
\hline DU-1 & 1365 & 2.87 & 16.87 & 80.26 & 8.28 & 11.46 & 80.26 \\
\hline DU-1 & 1380 & 1.00 & 7.65 & 91.35 & 3.32 & 5.34 & 91.35 \\
\hline Dப-1 & 1395 & 1.02 & 7.79 & 91.19 & 3.19 & 5.62 & 91.19 \\
\hline DU-1 & 1410 & 2.87 & 16.43 & 80.70 & 7.71 & 11.59 & 80.70 \\
\hline Dப-1 & 1425 & 2.15 & 15.24 & 82.61 & 6.25 & 11.15 & 82.61 \\
\hline Dப-1 & 1440 & 7.67 & 57.28 & 35.04 & 22.71 & 42.25 & 35.04 \\
\hline DU-1 & 1455 & 3.35 & 20.48 & 76.17 & 9.28 & 14.55 & 76.17 \\
\hline DU-1 & 1470 & 2.25 & 15.95 & 81.80 & 6.71 & 11.50 & 81.80 \\
\hline Dப-1 & 1485 & 2.55 & 22.63 & 74.82 & 7.65 & 17.53 & 74.82 \\
\hline
\end{tabular}




\begin{tabular}{|c|c|c|c|c|c|c|c|}
\hline Dப-1 & 1500 & 4.99 & 38.05 & 56.95 & 14.27 & 28.78 & 56.95 \\
\hline DU-1 & 1515 & 5.79 & 30.98 & 63.23 & 15.03 & 21.74 & 63.23 \\
\hline Dப-1 & 1530 & 12.40 & 58.64 & 28.96 & 31.08 & 39.97 & 28.96 \\
\hline DU-1 & 1545 & 5.98 & 33.05 & 60.97 & 15.55 & 23.49 & 60.97 \\
\hline Dப-1 & 1560 & 6.80 & 33.17 & 60.03 & 17.05 & 22.91 & 60.03 \\
\hline Dப-1 & 1575 & 10.83 & 53.89 & 35.28 & 27.54 & 37.18 & 35.28 \\
\hline Dப-1 & 1590 & 5.84 & 36.17 & 58.00 & 16.17 & 25.83 & 58.00 \\
\hline Dப-1 & 1605 & 5.16 & 37.48 & 57.36 & 15.50 & 27.14 & 57.36 \\
\hline Dப-1 & 1620 & 8.62 & 44.90 & 46.47 & 23.06 & 30.47 & 46.47 \\
\hline Dப-1 & 1635 & 9.37 & 51.49 & 39.14 & 25.06 & 35.79 & 39.14 \\
\hline Dப-1 & 1650 & 1.57 & 15.95 & 82.48 & 5.13 & 12.39 & 82.48 \\
\hline Dப-1 & 1665 & 2.08 & 19.05 & 78.87 & 6.74 & 14.39 & 78.87 \\
\hline Dப-1 & 1680 & 3.05 & 25.85 & 71.10 & 9.41 & 19.49 & 71.10 \\
\hline Dப-1 & 1695 & 1.53 & 14.15 & 84.33 & 5.04 & 10.64 & 84.33 \\
\hline Dப-1 & 1710 & 5.04 & 37.25 & 57.71 & 14.88 & 27.41 & 57.71 \\
\hline Dப-1 & 1725 & 2.32 & 21.56 & 76.12 & 7.13 & 16.75 & 76.12 \\
\hline Dப-1 & 1740 & 5.97 & 41.33 & 52.70 & 17.21 & 30.09 & 52.70 \\
\hline Dப-1 & 1755 & 2.00 & 10.98 & 87.02 & 5.41 & 7.57 & 87.02 \\
\hline DU-1 & 1770 & 4.35 & 31.64 & 64.00 & 12.42 & 23.58 & 64.00 \\
\hline Dப-1 & 1785 & 6.73 & 36.00 & 57.27 & 17.87 & 24.86 & 57.27 \\
\hline Dப-1 & 1810 & 1.83 & 15.45 & 82.72 & 5.96 & 11.31 & 82.72 \\
\hline Dப-1 & 1815 & 5.38 & 44.98 & 49.64 & 16.48 & 33.88 & 49.64 \\
\hline Dப-1 & 1830 & 1.75 & 16.06 & 82.19 & 5.67 & 12.14 & 82.19 \\
\hline DU-1 & 1845 & 0.79 & 9.46 & 89.75 & 2.92 & 7.33 & 89.75 \\
\hline Dப-1 & 1860 & 4.10 & 38.47 & 57.42 & 12.71 & 29.86 & 57.42 \\
\hline Dப-1 & 1875 & 2.67 & 24.68 & 72.65 & 8.34 & 19.02 & 72.65 \\
\hline DU-1 & 1890 & 2.45 & 20.49 & 77.06 & 7.70 & 15.24 & 77.06 \\
\hline Dப-1 & 1905 & 2.62 & 14.64 & 82.74 & 7.22 & 10.05 & 82.74 \\
\hline Dப-1 & 1920 & 1.00 & 11.09 & 87.91 & 3.51 & 8.58 & 87.91 \\
\hline DU-1 & 1935 & 1.39 & 9.86 & 88.74 & 4.47 & 6.79 & 88.74 \\
\hline Dப-1 & 1950 & 4.03 & 24.28 & 71.69 & 11.71 & 16.60 & 71.69 \\
\hline Dப-1 & 1965 & 0.32 & 4.66 & 95.03 & 0.00 & 0.00 & 95.03 \\
\hline Dப-1 & 1980 & 2.02 & 15.19 & 82.79 & 6.10 & 11.11 & 82.79 \\
\hline Dப-1 & 1995 & 1.91 & 15.34 & 82.75 & 5.86 & 11.39 & 82.75 \\
\hline DU-1 & 2010 & 3.92 & 36.28 & 59.80 & 12.02 & 28.18 & 59.80 \\
\hline Dப-1 & 2025 & 1.25 & 10.25 & 88.51 & 4.02 & 7.47 & 88.51 \\
\hline Dப-1 & 2040 & 1.27 & 13.98 & 84.75 & 4.20 & 11.06 & 84.75 \\
\hline DU-1 & 2055 & 1.01 & 7.84 & 91.15 & 3.39 & 5.46 & 91.15 \\
\hline Dப-1 & 2070 & 1.27 & 9.13 & 89.60 & 4.08 & 6.32 & 89.60 \\
\hline Dப-1 & 2085 & 0.86 & 7.52 & 91.63 & 2.90 & 5.48 & 91.63 \\
\hline Dப-1 & 2100 & 3.47 & 28.21 & 68.31 & 10.08 & 21.60 & 68.31 \\
\hline Dப-1 & 2115 & 5.97 & 40.39 & 53.64 & 17.11 & 29.25 & 53.64 \\
\hline Dப-1 & 2130 & 2.34 & 10.61 & 87.05 & 6.82 & 6.14 & 87.05 \\
\hline Dப-1 & 2145 & 0.50 & 6.81 & 92.70 & 2.08 & 5.22 & 92.70 \\
\hline Dப-1 & 2160 & 0.60 & 7.38 & 92.03 & 2.07 & 5.90 & 92.03 \\
\hline DU-1 & 2175 & 0.37 & 6.42 & 93.21 & 1.39 & 5.40 & 93.21 \\
\hline Dப-1 & 2190 & 0.24 & 4.42 & 95.34 & 1.22 & 3.44 & 95.34 \\
\hline
\end{tabular}




\begin{tabular}{|c|c|c|c|c|c|c|c|}
\hline Dப-1 & 2205 & 0.38 & 6.44 & 93.18 & 1.61 & 5.21 & 93.18 \\
\hline DU-1 & 2220 & 1.39 & 14.12 & 84.48 & 4.43 & 11.08 & 84.48 \\
\hline Dப-1 & 2235 & 0.61 & 8.78 & 90.61 & 2.35 & 7.04 & 90.61 \\
\hline DU-1 & 2250 & 3.17 & 25.90 & 70.92 & 9.39 & 19.69 & 70.92 \\
\hline Dப-1 & 2265 & 0.97 & 9.40 & 89.63 & 3.34 & 7.02 & 89.63 \\
\hline Dப-1 & 2280 & 1.30 & 11.30 & 87.40 & 4.26 & 8.34 & 87.40 \\
\hline Dப-1 & 2295 & 2.06 & 16.41 & 81.53 & 6.14 & 12.33 & 81.53 \\
\hline Dப-1 & 2310 & 1.50 & 11.45 & 87.05 & 4.63 & 8.31 & 87.05 \\
\hline Dப-1 & 2325 & 1.38 & 10.09 & 88.53 & 4.10 & 7.37 & 88.53 \\
\hline Dப-1 & 2340 & 1.76 & 14.16 & 84.08 & 5.19 & 10.73 & 84.08 \\
\hline Dப-1 & 2355 & 2.50 & 18.72 & 78.79 & 7.61 & 13.60 & 78.79 \\
\hline Dப-1 & 2370 & 1.23 & 14.08 & 84.68 & 3.99 & 11.32 & 84.68 \\
\hline Dப-1 & 2385 & 1.86 & 26.54 & 71.60 & 5.49 & 22.91 & 71.60 \\
\hline Dப-1 & 2400 & 1.66 & 27.82 & 70.51 & 4.69 & 24.80 & 70.51 \\
\hline DU-1 & 2415 & 1.69 & 26.94 & 71.37 & 4.91 & 23.72 & 71.37 \\
\hline Dப-1 & 2430 & 2.95 & 36.96 & 60.09 & 8.65 & 31.27 & 60.09 \\
\hline Dப-1 & 2445 & 2.41 & 23.06 & 74.53 & 7.14 & 18.33 & 74.53 \\
\hline Dப-1 & 2460 & 2.15 & 24.29 & 73.55 & 6.46 & 19.99 & 73.55 \\
\hline Dப-1 & 2475 & 1.03 & 14.13 & 84.85 & 3.62 & 11.53 & 84.85 \\
\hline Dப-1 & 2490 & 1.69 & 15.31 & 83.00 & 5.64 & 11.37 & 83.00 \\
\hline DU-1 & 2505 & 0.98 & 9.65 & 89.37 & 3.56 & 7.07 & 89.37 \\
\hline Dப-1 & 2535 & 2.27 & 15.71 & 82.03 & 7.06 & 10.91 & 82.03 \\
\hline DU-1 & 2520 & 1.15 & 11.83 & 87.03 & 4.10 & 8.87 & 87.03 \\
\hline Dப-1 & 2550 & 3.47 & 23.47 & 73.06 & 9.81 & 17.13 & 73.06 \\
\hline Dப-1 & 2565 & 1.59 & 11.84 & 86.58 & 4.89 & 8.54 & 86.58 \\
\hline DU-1 & 2580 & 2.21 & 15.54 & 82.25 & 6.39 & 11.36 & 82.25 \\
\hline Dப-1 & 2595 & 2.34 & 19.93 & 77.72 & 6.88 & 15.40 & 77.72 \\
\hline Dப-1 & 2610 & 2.52 & 24.54 & 72.94 & 7.67 & 19.38 & 72.94 \\
\hline Dப-1 & 2625 & 0.89 & 7.26 & 91.85 & 2.91 & 5.24 & 91.85 \\
\hline Dப-1 & 2640 & 2.99 & 20.98 & 76.04 & 8.72 & 15.24 & 76.04 \\
\hline Dப-1 & 2655 & 0.92 & 7.55 & 91.53 & 3.10 & 5.37 & 91.53 \\
\hline Dப-1 & 2670 & 0.00 & 2.01 & 97.99 & 0.07 & 1.94 & 97.99 \\
\hline Dப-1 & 2685 & 0.00 & 1.78 & 98.22 & 0.01 & 1.77 & 98.22 \\
\hline DU-1 & 2700 & 0.09 & 3.59 & 96.32 & 0.64 & 3.04 & 96.32 \\
\hline Dப-1 & 2715 & 1.21 & 15.20 & 83.59 & 4.02 & 12.39 & 83.59 \\
\hline Dப-1 & 2730 & 0.80 & 12.61 & 86.58 & 2.76 & 10.66 & 86.58 \\
\hline Dப-1 & 2745 & 1.21 & 15.52 & 83.28 & 3.88 & 12.84 & 83.28 \\
\hline Dப-1 & 2760 & 0.38 & 12.14 & 87.48 & 1.80 & 10.72 & 87.48 \\
\hline Dப-1 & 2775 & 0.86 & 8.51 & 90.63 & 2.82 & 6.55 & 90.63 \\
\hline Dப-1 & 2790 & 1.41 & 11.75 & 86.85 & 4.48 & 8.68 & 86.85 \\
\hline Dப-1 & 2805 & 1.18 & 9.80 & 89.02 & 3.94 & 7.03 & 89.02 \\
\hline Dப-1 & 2820 & 1.76 & 21.36 & 76.89 & 5.61 & 17.50 & 76.89 \\
\hline Dப-1 & 2835 & 0.19 & 6.01 & 93.81 & 1.32 & 4.87 & 93.81 \\
\hline Dப-1 & 2850 & 3.17 & 30.91 & 65.92 & 9.89 & 24.19 & 65.92 \\
\hline Dப-1 & 2865 & 1.30 & 10.16 & 88.54 & 3.97 & 7.49 & 88.54 \\
\hline Dப-1 & 2880 & 0.59 & 5.68 & 93.73 & 2.13 & 4.14 & 93.73 \\
\hline Dப-1 & 2895 & 5.00 & 25.52 & 69.48 & 13.87 & 16.65 & 69.48 \\
\hline
\end{tabular}




\begin{tabular}{|c|c|c|c|c|c|c|c|}
\hline Dப-1 & 2910 & 0.45 & 6.34 & 93.22 & 1.83 & 4.95 & 93.22 \\
\hline DU-1 & 2925 & 2.35 & 11.54 & 86.12 & 6.77 & 7.11 & 86.12 \\
\hline Dப-1 & 2940 & 3.41 & 18.79 & 77.80 & 9.60 & 12.60 & 77.80 \\
\hline Dப-1 & 2955 & 2.38 & 10.94 & 86.69 & 7.01 & 6.31 & 86.69 \\
\hline Dப-1 & 2970 & 2.03 & 12.61 & 85.36 & 6.02 & 8.62 & 85.36 \\
\hline Dப-1 & 2985 & 0.39 & 4.70 & 94.92 & 1.65 & 3.43 & 94.92 \\
\hline Dப-1 & 3000 & 3.66 & 30.08 & 66.26 & 11.73 & 22.01 & 66.26 \\
\hline DU-1 & 3015 & 2.59 & 20.53 & 76.88 & 7.93 & 15.19 & 76.88 \\
\hline Dப-1 & 3030 & 1.48 & 11.76 & 86.76 & 4.72 & 8.52 & 86.76 \\
\hline Dப-1 & 3045 & 2.46 & 47.07 & 50.47 & 6.69 & 42.83 & 50.47 \\
\hline Dப-1 & 3060 & 0.82 & 11.96 & 87.22 & 2.81 & 9.97 & 87.22 \\
\hline Dப-1 & 3075 & 1.73 & 19.34 & 78.93 & 5.73 & 15.35 & 78.93 \\
\hline DU-1 & 3090 & 1.03 & 11.90 & 87.07 & 3.42 & 9.51 & 87.07 \\
\hline Dப-1 & 3105 & 0.86 & 9.36 & 89.78 & 2.94 & 7.29 & 89.78 \\
\hline Dப-1 & 3120 & 0.00 & 1.49 & 98.51 & 0.03 & 1.46 & 98.51 \\
\hline Dப-1 & 3135 & 0.08 & 3.79 & 96.13 & 0.79 & 3.08 & 96.13 \\
\hline Dப-1 & 3150 & 0.35 & 5.68 & 93.98 & 1.63 & 4.40 & 93.98 \\
\hline Dப-1 & 3165 & 0.65 & 4.94 & 94.41 & 2.08 & 3.51 & 94.41 \\
\hline DU-1 & 3180 & 2.64 & 13.37 & 84.00 & 7.01 & 9.00 & 84.00 \\
\hline Dப-1 & 3195 & 4.79 & 29.12 & 66.09 & 14.07 & 19.84 & 66.09 \\
\hline Dப-1 & 3210 & 6.70 & 28.65 & 64.65 & 17.51 & 17.84 & 64.65 \\
\hline Dப-1 & 3225 & 6.78 & 36.60 & 56.62 & 19.16 & 24.22 & 56.62 \\
\hline Dப-1 & 3240 & 6.84 & 33.31 & 59.85 & 18.40 & 21.75 & 59.85 \\
\hline DU-1 & 3255 & 0.76 & 5.10 & 94.14 & 2.40 & 3.46 & 94.14 \\
\hline Dப-1 & 3270 & 2.56 & 15.90 & 81.54 & 6.84 & 11.62 & 81.54 \\
\hline Dப-1 & 3285 & 1.63 & 9.30 & 89.07 & 4.52 & 6.41 & 89.07 \\
\hline Dப-1 & 3300 & 0.94 & 8.76 & 90.30 & 3.08 & 6.62 & 90.30 \\
\hline Dப-1 & 3315 & 2.16 & 20.54 & 77.29 & 6.82 & 15.88 & 77.29 \\
\hline Dப-1 & 3330 & 0.51 & 4.30 & 95.19 & 1.85 & 2.97 & 95.19 \\
\hline DU-1 & 3345 & 2.03 & 15.08 & 82.89 & 6.03 & 11.08 & 82.89 \\
\hline Dப-1 & 3360 & 0.88 & 8.37 & 90.75 & 3.02 & 6.23 & 90.75 \\
\hline Dப-1 & 3375 & 1.16 & 13.30 & 85.54 & 3.85 & 10.61 & 85.54 \\
\hline Dப-1 & 3390 & 0.13 & 3.92 & 95.96 & 0.90 & 3.14 & 95.96 \\
\hline Dப-1 & 3405 & 1.10 & 10.21 & 88.69 & 3.70 & 7.61 & 88.69 \\
\hline DU-1 & 3420 & 4.04 & 22.58 & 73.38 & 11.08 & 15.54 & 73.38 \\
\hline Dப-1 & 3435 & 3.28 & 17.22 & 79.50 & 8.80 & 11.70 & 79.50 \\
\hline Dப-1 & 3450 & 3.39 & 16.12 & 80.49 & 8.83 & 10.67 & 80.49 \\
\hline DU-1 & 3465 & 1.00 & 9.16 & 89.83 & 3.30 & 6.86 & 89.83 \\
\hline Dப-1 & 3480 & 1.53 & 12.26 & 86.22 & 4.78 & 9.00 & 86.22 \\
\hline Dப-1 & 3495 & 2.93 & 23.77 & 73.30 & 8.55 & 18.15 & 73.30 \\
\hline Dப-1 & 3510 & 0.78 & 7.40 & 91.82 & 2.58 & 5.60 & 91.82 \\
\hline Dப-1 & 3525 & 0.82 & 7.06 & 92.13 & 2.61 & 5.26 & 92.13 \\
\hline Dப-1 & 3540 & 0.26 & 5.68 & 94.06 & 1.33 & 4.61 & 94.06 \\
\hline Dப-1 & 3555 & 2.22 & 17.32 & 80.46 & 6.64 & 12.91 & 80.46 \\
\hline Dப-1 & 3570 & 1.64 & 13.00 & 85.36 & 5.30 & 9.34 & 85.36 \\
\hline Dப-1 & 3585 & 3.10 & 22.53 & 74.36 & 9.33 & 16.30 & 74.36 \\
\hline Dப-1 & 3600 & 1.21 & 12.13 & 86.66 & 4.00 & 9.34 & 86.66 \\
\hline
\end{tabular}




\begin{tabular}{|c|c|c|c|c|c|c|c|}
\hline Dப-1 & 3615 & 1.74 & 16.42 & 81.83 & 4.94 & 13.23 & 81.83 \\
\hline Dப-1 & 3630 & 4.77 & 37.42 & 57.81 & 13.89 & 28.30 & 57.81 \\
\hline Dப-1 & 3645 & 0.90 & 11.71 & 87.40 & 3.18 & 9.42 & 87.40 \\
\hline DU-1 & 3660 & 1.79 & 14.40 & 83.81 & 5.48 & 10.71 & 83.81 \\
\hline Dப-1 & 3675 & 0.36 & 4.04 & 95.59 & 1.59 & 2.81 & 95.59 \\
\hline Dப-1 & 3690 & 1.13 & 10.77 & 88.10 & 3.88 & 8.03 & 88.10 \\
\hline Dப-1 & 3705 & 0.67 & 6.98 & 92.35 & 2.33 & 5.32 & 92.35 \\
\hline DU-1 & 3720 & 0.66 & 6.65 & 92.69 & 2.31 & 5.00 & 92.69 \\
\hline DU-1 & 3735 & 0.59 & 6.76 & 92.65 & 2.10 & 5.25 & 92.65 \\
\hline Dப-1 & 3750 & 1.12 & 9.80 & 89.09 & 3.50 & 7.41 & 89.09 \\
\hline Dப-1 & 3765 & 0.94 & 5.60 & 93.46 & 2.89 & 3.66 & 93.46 \\
\hline Dப-1 & 3780 & 2.72 & 18.20 & 79.08 & 7.71 & 13.21 & 79.08 \\
\hline DU-1 & 3795 & 2.98 & 16.37 & 80.65 & 7.98 & 11.37 & 80.65 \\
\hline Dப-1 & 3810 & 0.45 & 3.85 & 95.70 & 1.67 & 2.63 & 95.70 \\
\hline Dப-1 & 3825 & 1.63 & 9.22 & 89.15 & 4.60 & 6.25 & 89.15 \\
\hline Dப-1 & 3840 & 1.52 & 6.72 & 91.76 & 4.04 & 4.19 & 91.76 \\
\hline Dப-1 & 3855 & 0.13 & 2.71 & 97.16 & 0.68 & 2.16 & 97.16 \\
\hline Dப-1 & 3870 & 3.77 & 21.07 & 75.17 & 9.78 & 15.05 & 75.17 \\
\hline DU-1 & 3885 & 1.49 & 6.05 & 92.46 & 3.99 & 3.56 & 92.46 \\
\hline Dப-1 & 3900 & 1.86 & 9.83 & 88.31 & 5.10 & 6.59 & 88.31 \\
\hline Dப-1 & 3915 & 0.84 & 7.03 & 92.13 & 2.50 & 5.36 & 92.13 \\
\hline Dப-1 & 3930 & 2.17 & 10.21 & 87.62 & 5.73 & 6.65 & 87.62 \\
\hline Dப-1 & 3945 & 1.13 & 5.37 & 93.50 & 3.56 & 2.94 & 93.50 \\
\hline DU-1 & 3960 & 0.47 & 4.36 & 95.17 & 1.94 & 2.89 & 95.17 \\
\hline Dப-1 & 3975 & 0.34 & 2.85 & 96.81 & 1.21 & 1.98 & 96.81 \\
\hline Dப-1 & 3990 & 2.89 & 22.82 & 74.30 & 8.60 & 17.10 & 74.30 \\
\hline Dப-1 & 4005 & 2.95 & 26.44 & 70.61 & 8.74 & 20.65 & 70.61 \\
\hline Dப-1 & 4020 & 5.10 & 32.84 & 62.06 & 14.71 & 23.23 & 62.06 \\
\hline Dப-1 & 4035 & 3.96 & 34.54 & 61.51 & 11.66 & 26.83 & 61.51 \\
\hline DU-1 & 4050 & 1.24 & 12.37 & 86.39 & 4.01 & 9.60 & 86.39 \\
\hline Dப-1 & 4065 & 3.33 & 19.66 & 77.01 & 9.24 & 13.75 & 77.01 \\
\hline Dப-1 & 4080 & 0.68 & 16.06 & 83.26 & 2.71 & 14.03 & 83.26 \\
\hline Dப-1 & 4095 & 2.31 & 14.68 & 83.02 & 6.39 & 10.59 & 83.02 \\
\hline Dப-1 & 4110 & 2.79 & 23.78 & 73.43 & 11.11 & 15.46 & 73.43 \\
\hline DU-1 & 4125 & 3.04 & 14.10 & 82.87 & 7.66 & 9.48 & 82.87 \\
\hline Dப-1 & 4140 & 4.20 & 24.82 & 70.98 & 11.46 & 17.57 & 70.98 \\
\hline Dப-1 & 4155 & 4.67 & 24.65 & 70.68 & 13.08 & 16.24 & 70.68 \\
\hline DU-1 & 4170 & 1.37 & 9.94 & 88.70 & 4.13 & 7.17 & 88.70 \\
\hline Dப-1 & 4185 & 7.76 & 46.65 & 45.59 & 21.16 & 33.26 & 45.59 \\
\hline Dப-1 & 4200 & 3.16 & 15.55 & 81.29 & 8.42 & 10.29 & 81.29 \\
\hline Dப-1 & 4215 & 5.38 & 33.73 & 60.89 & 15.75 & 23.36 & 60.89 \\
\hline Dப-1 & 4230 & 3.93 & 26.62 & 69.45 & 11.29 & 19.26 & 69.45 \\
\hline Dப-1 & 4245 & 0.71 & 12.26 & 87.03 & 2.66 & 10.31 & 87.03 \\
\hline Dப-1 & 4260 & 3.97 & 20.52 & 75.51 & 10.39 & 14.11 & 75.51 \\
\hline Dப-1 & 4275 & 0.29 & 4.48 & 95.23 & 1.41 & 3.36 & 95.23 \\
\hline Dப-1 & 4290 & 3.30 & 22.51 & 74.18 & 9.58 & 16.24 & 74.18 \\
\hline Dப-1 & 4305 & 2.42 & 17.10 & 80.48 & 7.14 & 12.38 & 80.48 \\
\hline
\end{tabular}




\begin{tabular}{|c|c|c|c|c|c|c|c|}
\hline DU-1 & 4320 & 5.14 & 31.82 & 63.04 & 14.26 & 22.70 & 63.04 \\
\hline DU-1 & 4335 & 5.35 & 27.32 & 67.33 & 13.69 & 18.98 & 67.33 \\
\hline Dப-1 & 4350 & 1.66 & 15.34 & 83.00 & 5.29 & 11.71 & 83.00 \\
\hline Dப-1 & 4365 & 2.66 & 21.58 & 75.76 & 8.32 & 15.92 & 75.76 \\
\hline Dப-1 & 4380 & 1.52 & 12.37 & 86.10 & 4.93 & 8.97 & 86.10 \\
\hline DU-1 & 4395 & 2.06 & 19.63 & 78.31 & 6.67 & 15.02 & 78.31 \\
\hline Dப-1 & 4410 & 1.85 & 17.54 & 80.62 & 5.88 & 13.50 & 80.62 \\
\hline Dப-1 & 4420 & 1.85 & 17.75 & 80.40 & 5.95 & 13.65 & 80.40 \\
\hline Dப-1 & 4425 & 3.83 & 16.10 & 80.07 & 9.61 & 10.33 & 80.07 \\
\hline Dப-1 & 4440 & 2.73 & 29.60 & 67.67 & 8.50 & 23.83 & 67.67 \\
\hline Dப-1 & 4455 & 2.22 & 15.76 & 82.01 & 6.67 & 11.31 & 82.01 \\
\hline Dப-1 & 4485 & 0.88 & 10.15 & 88.96 & 3.12 & 7.92 & 88.96 \\
\hline Dப-1 & 4500 & 1.19 & 13.32 & 85.48 & 4.03 & 10.49 & 85.48 \\
\hline Dப-1 & 4515 & 2.42 & 15.16 & 82.42 & 6.91 & 10.66 & 82.42 \\
\hline Dப-1 & 4530 & 2.12 & 11.40 & 86.48 & 5.93 & 7.58 & 86.48 \\
\hline Dப-1 & 4545 & 3.25 & 20.95 & 75.80 & 9.45 & 14.75 & 75.80 \\
\hline DU-1 & 4560 & 4.02 & 26.12 & 69.87 & 11.67 & 18.46 & 69.87 \\
\hline DU-1 & 4575 & 1.69 & 14.32 & 83.99 & 5.34 & 10.68 & 83.99 \\
\hline DU-1 & 4590 & 1.34 & 10.56 & 88.11 & 4.23 & 7.66 & 88.11 \\
\hline DU-1 & 4605 & 4.67 & 27.74 & 67.58 & 13.08 & 19.34 & 67.58 \\
\hline Dப-1 & 4620 & 4.93 & 32.73 & 62.34 & 13.76 & 23.90 & 62.34 \\
\hline Dப-1 & 4635 & 4.04 & 31.51 & 64.46 & 12.29 & 23.25 & 64.46 \\
\hline DU-1 & 4650 & 0.51 & 6.21 & 93.27 & 2.25 & 4.47 & 93.27 \\
\hline Dப-1 & 4665 & 1.02 & 9.77 & 89.21 & 3.65 & 7.14 & 89.21 \\
\hline DU-1 & 4680 & 0.57 & 3.14 & 96.29 & 1.88 & 1.83 & 96.29 \\
\hline Dப-1 & 4695 & 0.43 & 3.48 & 96.09 & 1.65 & 2.26 & 96.09 \\
\hline Dப-1 & 4710 & 0.00 & 1.33 & 98.67 & 0.08 & 1.25 & 98.67 \\
\hline Dப-1 & 4725 & 0.68 & 6.20 & 93.12 & 2.13 & 4.75 & 93.12 \\
\hline DU-1 & 4740 & 0.81 & 8.39 & 90.80 & 2.75 & 6.45 & 90.80 \\
\hline Dப-1 & 4755 & 2.91 & 30.00 & 67.10 & 8.82 & 24.08 & 67.10 \\
\hline Dப-1 & 4770 & 2.37 & 24.12 & 73.50 & 7.26 & 19.24 & 73.50 \\
\hline Dப-1 & 4785 & 2.87 & 29.31 & 67.82 & 8.67 & 23.51 & 67.82 \\
\hline Dப-1 & 4800 & 1.01 & 12.35 & 86.64 & 3.51 & 9.85 & 86.64 \\
\hline DU-1 & 4815 & 2.37 & 19.27 & 78.36 & 7.01 & 14.62 & 78.36 \\
\hline DU-1 & 4830 & 1.15 & 13.19 & 85.66 & 4.01 & 10.33 & 85.66 \\
\hline Dப-1 & 4845 & 0.98 & 10.71 & 88.31 & 3.56 & 8.13 & 88.31 \\
\hline Dப-1 & 4860 & 1.56 & 15.82 & 82.63 & 5.19 & 12.19 & 82.63 \\
\hline Dப-1 & 4875 & 2.35 & 18.03 & 79.62 & 7.25 & 13.13 & 79.62 \\
\hline DU-1 & 4890 & 4.57 & 26.95 & 68.48 & 13.09 & 18.44 & 68.48 \\
\hline DU-1 & 4905 & 6.55 & 31.51 & 61.93 & 17.48 & 20.59 & 61.93 \\
\hline Dப-1 & 4920 & 4.75 & 33.50 & 61.74 & 13.35 & 24.91 & 61.74 \\
\hline DU-1 & 4935 & 2.11 & 13.58 & 84.31 & 5.79 & 9.90 & 84.31 \\
\hline Dப-1 & 4950 & 4.57 & 24.81 & 70.62 & 11.90 & 17.48 & 70.62 \\
\hline Dப-1 & 4965 & 2.95 & 18.94 & 78.11 & 8.37 & 13.52 & 78.11 \\
\hline DU-1 & 4980 & 6.02 & 36.08 & 57.90 & 16.18 & 25.92 & 57.90 \\
\hline DU-1 & 4995 & 1.31 & 14.14 & 84.55 & 4.23 & 11.22 & 84.55 \\
\hline Dப-1 & 5010 & 1.56 & 22.52 & 75.93 & 4.64 & 19.43 & 75.93 \\
\hline
\end{tabular}




\begin{tabular}{|c|c|c|c|c|c|c|c|}
\hline Dப-1 & 5025 & 4.31 & 48.89 & 46.80 & 10.80 & 42.39 & 46.80 \\
\hline DU-1 & 5040 & 0.37 & 6.24 & 93.39 & 1.57 & 5.03 & 93.39 \\
\hline Dப-1 & 5055 & 0.06 & 4.16 & 95.78 & 0.86 & 3.36 & 95.78 \\
\hline DU-1 & 5070 & 0.91 & 18.85 & 80.24 & 3.13 & 16.63 & 80.24 \\
\hline DU-1 & 5085 & 1.54 & 16.12 & 82.34 & 4.82 & 12.83 & 82.34 \\
\hline Dப-1 & 5100 & 1.31 & 18.02 & 80.67 & 4.12 & 15.20 & 80.67 \\
\hline DL-1 & 5115 & 0.21 & 5.08 & 94.72 & 1.05 & 4.24 & 94.72 \\
\hline DU-1 & 5130 & 1.11 & 17.74 & 81.15 & 3.54 & 15.31 & 81.15 \\
\hline DU-1 & 5145 & 0.24 & 5.32 & 94.44 & 1.26 & 4.30 & 94.44 \\
\hline Dப-1 & 5160 & 1.52 & 23.11 & 75.37 & 4.67 & 19.95 & 75.37 \\
\hline Dப-1 & 5175 & 1.20 & 16.00 & 82.80 & 3.56 & 13.64 & 82.80 \\
\hline Dப-1 & 5190 & 0.15 & 4.92 & 94.94 & 0.90 & 4.16 & 94.94 \\
\hline DU-1 & 5205 & 0.29 & 8.34 & 91.37 & 1.28 & 7.34 & 91.37 \\
\hline Dப-1 & 5220 & 0.64 & 11.64 & 87.72 & 2.29 & 9.99 & 87.72 \\
\hline DU-1 & 5235 & 4.72 & 19.81 & 75.47 & 10.03 & 14.50 & 75.47 \\
\hline Dப-1 & 5250 & 4.84 & 18.89 & 76.27 & 11.34 & 12.39 & 76.27 \\
\hline Dப-1 & 5265 & 2.51 & 20.96 & 76.53 & 6.51 & 16.97 & 76.53 \\
\hline Dப-1 & 5280 & 4.51 & 31.18 & 64.30 & 11.56 & 24.14 & 64.30 \\
\hline DU-1 & 5295 & 3.51 & 25.89 & 70.60 & 9.79 & 19.61 & 70.60 \\
\hline DU-1 & 5310 & 4.59 & 27.01 & 68.40 & 12.38 & 19.22 & 68.40 \\
\hline Dப-1 & 5325 & 5.51 & 34.53 & 59.96 & 15.97 & 24.07 & 59.96 \\
\hline Dப-1 & 5340 & 8.92 & 35.66 & 55.43 & 23.28 & 21.29 & 55.43 \\
\hline DU-1 & 5355 & 2.63 & 18.60 & 78.76 & 7.57 & 13.67 & 78.76 \\
\hline DU-1 & 5370 & 3.98 & 47.61 & 48.41 & 10.14 & 41.46 & 48.41 \\
\hline Dப-1 & 5385 & 2.02 & 41.62 & 56.36 & 5.15 & 38.49 & 56.36 \\
\hline Dப-1 & 5400 & 2.92 & 59.23 & 37.85 & 7.83 & 54.32 & 37.85 \\
\hline DU-1 & 5415 & 2.48 & 51.51 & 46.01 & 6.85 & 47.14 & 46.01 \\
\hline Dப-1 & 5430 & 1.97 & 65.88 & 32.14 & 4.98 & 62.88 & 32.14 \\
\hline Dப-1 & 5445 & 3.14 & 75.19 & 21.68 & 8.18 & 70.15 & 21.68 \\
\hline Dப-1 & 5460 & 2.07 & 62.97 & 34.96 & 5.31 & 59.73 & 34.96 \\
\hline Dப-1 & 5475 & 2.21 & 80.19 & 17.60 & 4.86 & 77.54 & 17.60 \\
\hline DU-1 & 5490 & 2.44 & 73.82 & 23.74 & 6.05 & 70.21 & 23.74 \\
\hline Dப-1 & 5505 & 5.29 & 77.85 & 16.86 & 12.14 & 71.00 & 16.86 \\
\hline Dப-1 & 5520 & 2.09 & 87.88 & 10.03 & 4.91 & 85.06 & 10.03 \\
\hline DU-1 & 5535 & 0.40 & 7.27 & 92.34 & 1.57 & 6.09 & 92.34 \\
\hline Dப-1 & 5550 & 0.77 & 9.10 & 90.13 & 2.81 & 7.06 & 90.13 \\
\hline Dப-1 & 5565 & 1.38 & 15.33 & 83.29 & 4.38 & 12.33 & 83.29 \\
\hline DU-1 & 5580 & 0.80 & 11.33 & 87.87 & 2.86 & 9.26 & 87.87 \\
\hline DL-1 & 5595 & 0.71 & 8.50 & 90.79 & 2.56 & 6.65 & 90.79 \\
\hline Dப-1 & 5610 & 0.76 & 9.50 & 89.74 & 2.70 & 7.56 & 89.74 \\
\hline Dப-1 & 5625 & 1.49 & 28.99 & 69.52 & 4.06 & 26.42 & 69.52 \\
\hline DU-1 & 5640 & 2.48 & 37.14 & 60.38 & 6.80 & 32.83 & 60.38 \\
\hline DU-1 & 5655 & 1.93 & 42.72 & 55.34 & 5.25 & 39.41 & 55.34 \\
\hline Dப-1 & 5670 & 1.12 & 11.08 & 87.80 & 3.97 & 8.24 & 87.80 \\
\hline Dப-1 & 5685 & 2.52 & 20.89 & 76.59 & 7.12 & 16.29 & 76.59 \\
\hline DU-1 & 5700 & 2.03 & 22.74 & 75.23 & 6.61 & 18.16 & 75.23 \\
\hline DU-1 & 5715 & 3.09 & 27.24 & 69.67 & 9.21 & 21.13 & 69.67 \\
\hline
\end{tabular}




\begin{tabular}{|c|c|c|c|c|c|c|c|}
\hline Dப-1 & 5730 & 5.24 & 28.86 & 65.89 & 13.27 & 20.84 & 65.89 \\
\hline DU-1 & 5745 & 1.33 & 10.51 & 88.16 & 4.03 & 7.81 & 88.16 \\
\hline Dப-1 & 5760 & 2.84 & 52.69 & 44.47 & 7.57 & 47.96 & 44.47 \\
\hline Dப-1 & 5775 & 1.32 & 26.13 & 72.55 & 3.44 & 24.01 & 72.55 \\
\hline Dப-1 & 5790 & 1.58 & 22.37 & 76.06 & 4.27 & 19.67 & 76.06 \\
\hline Dப-1 & 5805 & 0.98 & 19.55 & 79.48 & 3.01 & 17.52 & 79.48 \\
\hline Dப-1 & 5820 & 1.55 & 23.37 & 75.08 & 4.95 & 19.97 & 75.08 \\
\hline DU-1 & 5835 & 2.33 & 16.01 & 81.65 & 6.25 & 12.09 & 81.65 \\
\hline Dப-1 & 5850 & 1.01 & 10.90 & 88.09 & 2.96 & 8.95 & 88.09 \\
\hline Dப-1 & 5865 & 0.68 & 7.03 & 92.29 & 2.20 & 5.51 & 92.29 \\
\hline Dப-1 & 5880 & 2.00 & 13.15 & 84.85 & 5.23 & 9.91 & 84.85 \\
\hline Dப-1 & 5895 & 1.69 & 15.46 & 82.85 & 4.77 & 12.39 & 82.85 \\
\hline Dப-1 & 5910 & 0.84 & 7.60 & 91.56 & 2.60 & 5.85 & 91.56 \\
\hline Dப-1 & 5925 & 1.41 & 18.98 & 79.61 & 4.10 & 16.29 & 79.61 \\
\hline Dப-1 & 5940 & 3.27 & 29.55 & 67.18 & 10.02 & 22.80 & 67.18 \\
\hline Dப-1 & 5955 & 2.73 & 20.34 & 76.94 & 7.85 & 15.21 & 76.94 \\
\hline Dப-1 & 5970 & 1.63 & 14.06 & 84.31 & 4.65 & 11.04 & 84.31 \\
\hline Dப-1 & 5985 & 2.56 & 22.23 & 75.21 & 6.63 & 18.16 & 75.21 \\
\hline DU-1 & 6000 & 4.60 & 26.04 & 69.36 & 11.52 & 19.12 & 69.36 \\
\hline Dப-1 & 6015 & 5.30 & 36.56 & 58.14 & 13.59 & 28.27 & 58.14 \\
\hline Dப-1 & 6030 & 2.37 & 21.32 & 76.30 & 6.54 & 17.16 & 76.30 \\
\hline Dப-1 & 6045 & 2.38 & 22.28 & 75.33 & 6.31 & 18.36 & 75.33 \\
\hline Dப-1 & 6060 & 0.96 & 9.90 & 89.13 & 3.06 & 7.81 & 89.13 \\
\hline DU-1 & 6075 & 0.64 & 8.13 & 91.23 & 2.34 & 6.43 & 91.23 \\
\hline Dப-1 & 6090 & 1.09 & 13.13 & 85.77 & 3.87 & 10.35 & 85.77 \\
\hline Dப-1 & 6105 & 5.14 & 25.82 & 69.04 & 13.49 & 17.47 & 69.04 \\
\hline DU-1 & 6120 & 2.56 & 20.63 & 76.82 & 7.59 & 15.59 & 76.82 \\
\hline Dப-1 & 6135 & 2.32 & 21.43 & 76.25 & 6.89 & 16.86 & 76.25 \\
\hline Dப-1 & 6150 & 3.67 & 31.34 & 64.99 & 10.42 & 24.59 & 64.99 \\
\hline DU-1 & 6165 & 2.58 & 25.07 & 72.35 & 7.48 & 20.17 & 72.35 \\
\hline Dப-1 & 6180 & 2.55 & 27.14 & 70.31 & 7.36 & 22.33 & 70.31 \\
\hline Dப-1 & 6195 & 0.97 & 26.19 & 72.84 & 2.87 & 24.29 & 72.84 \\
\hline Dப-1 & 6210 & 1.02 & 23.30 & 75.68 & 3.28 & 21.04 & 75.68 \\
\hline Dப-1 & 6225 & 3.30 & 29.29 & 67.41 & 9.82 & 22.77 & 67.41 \\
\hline DU-1 & 6240 & 2.85 & 14.68 & 82.47 & 8.53 & 8.99 & 82.47 \\
\hline Dப-1 & 6255 & 2.52 & 15.15 & 82.34 & 7.11 & 10.55 & 82.34 \\
\hline Dப-1 & 6270 & 1.61 & 15.27 & 83.11 & 4.86 & 12.03 & 83.11 \\
\hline DU-1 & 6285 & 2.75 & 20.39 & 76.86 & 8.01 & 15.13 & 76.86 \\
\hline Dப-1 & 6300 & 5.01 & 40.49 & 54.50 & 14.81 & 30.69 & 54.50 \\
\hline Dப-1 & 6315 & 2.45 & 15.28 & 82.26 & 7.39 & 10.34 & 82.26 \\
\hline Dப-1 & 6330 & 1.65 & 12.17 & 86.19 & 5.26 & 8.55 & 86.19 \\
\hline Dப-1 & 6345 & 1.38 & 11.73 & 86.88 & 4.62 & 8.50 & 86.88 \\
\hline Dப-1 & 6360 & 1.22 & 10.62 & 88.16 & 4.11 & 7.73 & 88.16 \\
\hline Dப-1 & 6375 & 1.88 & 14.58 & 83.54 & 5.95 & 10.51 & 83.54 \\
\hline Dப-1 & 6390 & 1.13 & 11.02 & 87.85 & 3.85 & 8.30 & 87.85 \\
\hline DU-1 & 6405 & 0.64 & 7.08 & 92.28 & 2.33 & 5.39 & 92.28 \\
\hline Dப-1 & 6420 & 2.09 & 19.68 & 78.23 & 6.07 & 15.70 & 78.23 \\
\hline
\end{tabular}




\begin{tabular}{|c|c|c|c|c|c|c|c|}
\hline Dப-1 & 6435 & 1.92 & 18.38 & 79.70 & 5.42 & 14.88 & 79.70 \\
\hline DU-1 & 6450 & 0.29 & 4.16 & 95.55 & 1.26 & 3.19 & 95.55 \\
\hline Dப-1 & 6465 & 1.04 & 15.88 & 83.07 & 3.15 & 13.77 & 83.07 \\
\hline DU-1 & 6480 & 1.22 & 24.29 & 74.49 & 3.33 & 22.18 & 74.49 \\
\hline Dப-1 & 6495 & 1.42 & 31.82 & 66.76 & 4.03 & 29.21 & 66.76 \\
\hline Dப-1 & 6510 & 1.09 & 32.46 & 66.45 & 3.12 & 30.42 & 66.45 \\
\hline Dப-1 & 6525 & 0.53 & 21.36 & 78.11 & 1.59 & 20.29 & 78.11 \\
\hline DU-1 & 6540 & 1.65 & 27.02 & 71.33 & 4.56 & 24.11 & 71.33 \\
\hline Dப-1 & 6555 & 1.60 & 36.68 & 61.72 & 4.03 & 34.25 & 61.72 \\
\hline Dப-1 & 6570 & 2.21 & 26.20 & 71.58 & 6.03 & 22.39 & 71.58 \\
\hline Dப-1 & 6585 & 1.31 & 17.86 & 80.83 & 4.07 & 15.10 & 80.83 \\
\hline Dப-1 & 6600 & 6.63 & 25.61 & 67.75 & 16.21 & 16.03 & 67.75 \\
\hline DU-1 & 6615 & 5.17 & 18.56 & 76.26 & 11.99 & 11.75 & 76.26 \\
\hline Dப-1 & 6630 & 4.85 & 17.63 & 77.53 & 11.39 & 11.08 & 77.53 \\
\hline Dப-1 & 6645 & 4.31 & 13.98 & 81.71 & 9.67 & 8.62 & 81.71 \\
\hline Dப-1 & 6660 & 9.79 & 29.28 & 60.93 & 21.43 & 17.64 & 60.93 \\
\hline Dப-1 & 6675 & 4.58 & 17.08 & 78.33 & 11.10 & 10.57 & 78.33 \\
\hline Dப-1 & 6690 & 5.72 & 20.86 & 73.42 & 13.60 & 12.98 & 73.42 \\
\hline DU-1 & 6705 & 4.68 & 16.91 & 78.41 & 11.26 & 10.33 & 78.41 \\
\hline Dப-1 & 6720 & 6.51 & 28.27 & 65.21 & 16.15 & 18.63 & 65.21 \\
\hline Dப-1 & 6735 & 8.48 & 34.54 & 56.98 & 20.71 & 22.31 & 56.98 \\
\hline Dப-1 & 6750 & 6.89 & 27.99 & 65.12 & 16.74 & 18.14 & 65.12 \\
\hline Dப-1 & 6765 & 7.62 & 29.86 & 62.52 & 18.36 & 19.12 & 62.52 \\
\hline DU-1 & 6780 & 6.15 & 24.97 & 68.88 & 14.99 & 16.13 & 68.88 \\
\hline Dப-1 & 6795 & 7.69 & 31.36 & 60.95 & 18.66 & 20.39 & 60.95 \\
\hline Dப-1 & 6810 & 14.01 & 56.52 & 29.48 & 33.82 & 36.71 & 29.48 \\
\hline DU-1 & 6825 & 9.10 & 35.07 & 55.83 & 21.66 & 22.52 & 55.83 \\
\hline Dப-1 & 6840 & 4.86 & 19.49 & 75.65 & 11.93 & 12.43 & 75.65 \\
\hline Dப-1 & 6855 & 7.31 & 30.24 & 62.44 & 17.56 & 20.00 & 62.44 \\
\hline DU-1 & 6870 & 7.29 & 31.36 & 61.35 & 17.92 & 20.73 & 61.35 \\
\hline Dப-1 & 6885 & 5.76 & 23.37 & 70.87 & 14.01 & 15.12 & 70.87 \\
\hline Dப-1 & 6900 & 10.67 & 40.50 & 48.82 & 25.14 & 26.04 & 48.82 \\
\hline Dப-1 & 6915 & 13.29 & 48.24 & 38.46 & 30.84 & 30.70 & 38.46 \\
\hline Dப-1 & 6930 & 9.00 & 38.16 & 52.84 & 21.97 & 25.20 & 52.84 \\
\hline DU-1 & 6945 & 7.38 & 25.45 & 67.17 & 16.86 & 15.98 & 67.17 \\
\hline Dப-1 & 6960 & 4.64 & 20.46 & 74.89 & 11.70 & 13.41 & 74.89 \\
\hline Dப-1 & 6975 & 4.77 & 21.24 & 73.99 & 12.20 & 13.80 & 73.99 \\
\hline DU-1 & 6990 & 4.02 & 17.51 & 78.47 & 10.09 & 11.44 & 78.47 \\
\hline Dப-1 & 7005 & 4.87 & 15.85 & 79.27 & 11.14 & 9.58 & 79.27 \\
\hline Dப-1 & 7020 & 2.99 & 10.48 & 86.53 & 7.10 & 6.37 & 86.53 \\
\hline Dப-1 & 7035 & 8.95 & 30.73 & 60.32 & 20.80 & 18.88 & 60.32 \\
\hline Dப-1 & 7050 & 11.30 & 36.76 & 51.94 & 25.68 & 22.39 & 51.94 \\
\hline Dப-1 & 7065 & 1.01 & 8.49 & 90.51 & 2.97 & 6.53 & 90.51 \\
\hline Dப-1 & 7080 & 1.35 & 11.24 & 87.41 & 3.65 & 8.94 & 87.41 \\
\hline Dப-1 & 7095 & 0.69 & 16.08 & 83.23 & 2.25 & 14.52 & 83.23 \\
\hline DU-1 & 7110 & 3.87 & 20.97 & 75.16 & 9.28 & 15.56 & 75.16 \\
\hline Dப-1 & 7125 & 2.22 & 19.07 & 78.72 & 5.76 & 15.53 & 78.72 \\
\hline
\end{tabular}




\begin{tabular}{|c|c|c|c|c|c|c|c|}
\hline Dப-1 & 7140 & 3.53 & 23.48 & 72.99 & 9.03 & 17.98 & 72.99 \\
\hline DU-1 & 7155 & 1.93 & 11.68 & 86.39 & 5.19 & 8.42 & 86.39 \\
\hline DU-1 & 7170 & 6.16 & 33.33 & 60.51 & 15.39 & 24.11 & 60.51 \\
\hline Dப-1 & 7200 & 5.16 & 27.94 & 66.90 & 13.34 & 19.76 & 66.90 \\
\hline DU-1 & 7215 & 4.18 & 19.59 & 76.23 & 10.70 & 13.07 & 76.23 \\
\hline Dப-1 & 7230 & 6.26 & 31.15 & 62.59 & 15.78 & 21.63 & 62.59 \\
\hline Dப-1 & 7245 & 7.70 & 37.20 & 55.10 & 19.69 & 25.20 & 55.10 \\
\hline DU-1 & 7260 & 5.78 & 21.93 & 72.28 & 14.06 & 13.65 & 72.28 \\
\hline Dப-1 & 7275 & 4.17 & 11.43 & 84.41 & 9.79 & 5.80 & 84.41 \\
\hline Dப-1 & 7290 & 2.36 & 9.42 & 88.22 & 6.10 & 5.68 & 88.22 \\
\hline Dப-1 & 7305 & 1.44 & 6.14 & 92.42 & 4.26 & 3.32 & 92.42 \\
\hline Dப-1 & 7320 & 0.66 & 3.70 & 95.64 & 2.05 & 2.32 & 95.64 \\
\hline DU-1 & 7335 & 5.21 & 19.94 & 74.85 & 14.11 & 11.04 & 74.85 \\
\hline DU-1 & 7350 & 1.08 & 5.19 & 93.73 & 3.21 & 3.06 & 93.73 \\
\hline Dப-1 & 7365 & 3.78 & 14.35 & 81.87 & 10.21 & 7.93 & 81.87 \\
\hline Dப-1 & 7380 & 3.81 & 15.04 & 81.15 & 9.55 & 9.30 & 81.15 \\
\hline Dப-1 & 7395 & 6.94 & 31.44 & 61.61 & 17.90 & 20.49 & 61.61 \\
\hline Dப-1 & 7410 & 4.94 & 34.83 & 60.23 & 14.72 & 25.05 & 60.23 \\
\hline DU-1 & 7425 & 7.46 & 39.93 & 52.61 & 20.94 & 26.45 & 52.61 \\
\hline Dப-1 & 7440 & 5.98 & 25.54 & 68.48 & 15.68 & 15.84 & 68.48 \\
\hline Dப-1 & 7455 & 8.83 & 39.18 & 52.00 & 22.40 & 25.60 & 52.00 \\
\hline Dப-1 & 7470 & 9.93 & 36.58 & 53.49 & 24.60 & 21.91 & 53.49 \\
\hline DU-1 & 7485 & 4.53 & 27.79 & 67.67 & 11.99 & 20.34 & 67.67 \\
\hline DU-1 & 7500 & 2.84 & 20.98 & 76.19 & 8.13 & 15.69 & 76.19 \\
\hline Dப-1 & 7515 & 2.30 & 21.61 & 76.10 & 6.79 & 17.11 & 76.10 \\
\hline Dப-1 & 7530 & 2.61 & 22.69 & 74.70 & 7.46 & 17.84 & 74.70 \\
\hline DU-1 & 7545 & 1.82 & 15.62 & 82.56 & 4.99 & 12.45 & 82.56 \\
\hline Dப-1 & 7560 & 1.45 & 15.40 & 83.14 & 4.37 & 12.49 & 83.14 \\
\hline Dப-1 & 7575 & 0.91 & 13.45 & 85.64 & 2.79 & 11.57 & 85.64 \\
\hline DU-1 & 7590 & 2.12 & 27.95 & 69.93 & 5.95 & 24.12 & 69.93 \\
\hline Dப-1 & 7605 & 1.27 & 18.16 & 80.57 & 3.96 & 15.46 & 80.57 \\
\hline Dப-1 & 7620 & 2.21 & 21.74 & 76.05 & 6.47 & 17.48 & 76.05 \\
\hline Dப-1 & 7635 & 1.42 & 16.36 & 82.22 & 4.34 & 13.44 & 82.22 \\
\hline DU-1 & 7650 & 1.93 & 21.27 & 76.80 & 5.61 & 17.59 & 76.80 \\
\hline DU-2 & 165 & 1.07 & 22.50 & 76.44 & 5.14 & 18.42 & 76.44 \\
\hline Dப-2 & 315 & 7.05 & 40.23 & 52.72 & 19.60 & 27.68 & 52.72 \\
\hline Dப-2 & 465 & 10.14 & 45.43 & 44.42 & 25.24 & 30.34 & 44.42 \\
\hline Dப-2 & 615 & 7.72 & 39.41 & 52.87 & 18.35 & 28.78 & 52.87 \\
\hline Dப-2 & 765 & 3.20 & 15.88 & 80.92 & 8.74 & 10.34 & 80.92 \\
\hline Dப-2 & 915 & 7.15 & 49.30 & 43.55 & 18.34 & 38.11 & 43.55 \\
\hline Dப-2 & 1065 & 10.45 & 47.01 & 42.54 & 24.03 & 33.43 & 42.54 \\
\hline Dப-2 & 1215 & 7.08 & 50.35 & 42.57 & 16.65 & 40.78 & 42.57 \\
\hline Dப-2 & 1350 & 3.39 & 28.42 & 68.20 & 8.48 & 23.33 & 68.20 \\
\hline Dப-2 & 1365 & 7.62 & 40.93 & 51.45 & 18.48 & 30.07 & 51.45 \\
\hline Dப-2 & 1515 & 5.97 & 29.16 & 64.87 & 14.24 & 20.89 & 64.87 \\
\hline DU-2 & 1605 & 4.50 & 23.12 & 72.38 & 10.89 & 16.73 & 72.38 \\
\hline Dப-2 & 1725 & 8.24 & 44.43 & 47.33 & 19.56 & 33.11 & 47.33 \\
\hline
\end{tabular}




\begin{tabular}{|c|c|c|c|c|c|c|c|}
\hline Dப-2 & 1845 & 5.14 & 26.45 & 68.41 & 12.28 & 19.31 & 68.41 \\
\hline DU-2 & 1950 & 5.02 & 29.45 & 65.53 & 12.43 & 22.04 & 65.53 \\
\hline Dப-2 & 2040 & 2.27 & 17.72 & 80.01 & 6.13 & 13.86 & 80.01 \\
\hline Dப-2 & 2145 & 4.98 & 30.52 & 64.50 & 12.33 & 23.17 & 64.50 \\
\hline Dப-2 & 2235 & 7.75 & 40.63 & 51.62 & 18.72 & 29.66 & 51.62 \\
\hline Dப-2 & 2325 & 4.57 & 26.79 & 68.64 & 11.22 & 20.14 & 68.64 \\
\hline Dப-2 & 2400 & 7.09 & 32.57 & 60.34 & 16.59 & 23.07 & 60.34 \\
\hline Dப-2 & 2505 & 8.20 & 36.57 & 55.23 & 18.82 & 25.96 & 55.23 \\
\hline Dப-2 & 2595 & 6.67 & 32.44 & 60.89 & 15.79 & 23.32 & 60.89 \\
\hline DU-2 & 2700 & 7.91 & 34.55 & 57.53 & 18.44 & 24.03 & 57.53 \\
\hline Dப-2 & 2775 & 5.15 & 23.78 & 71.07 & 12.32 & 16.62 & 71.07 \\
\hline Dப-2 & 2865 & 5.61 & 31.50 & 62.89 & 13.86 & 23.24 & 62.89 \\
\hline Dப-2 & 2955 & 7.60 & 39.62 & 52.78 & 18.06 & 29.16 & 52.78 \\
\hline Dப-2 & 3045 & 8.15 & 41.24 & 50.61 & 19.69 & 29.71 & 50.61 \\
\hline Dப-2 & 3150 & 7.19 & 40.00 & 52.81 & 17.84 & 29.36 & 52.81 \\
\hline Dப-2 & 3180 & 5.46 & 57.05 & 37.49 & 15.13 & 47.38 & 37.49 \\
\hline Dப-2 & 3195 & 5.63 & 64.14 & 30.23 & 15.03 & 54.74 & 30.23 \\
\hline DU-2 & 3210 & 6.43 & 64.77 & 28.80 & 16.49 & 54.71 & 28.80 \\
\hline Dப-2 & 3225 & 7.57 & 59.60 & 32.83 & 18.80 & 48.38 & 32.83 \\
\hline Dப-2 & 3240 & 7.43 & 70.84 & 21.73 & 19.30 & 58.97 & 21.73 \\
\hline Dப-2 & 3270 & 15.56 & 80.24 & 4.20 & 49.11 & 46.69 & 4.20 \\
\hline Dப-2 & 3285 & 5.72 & 43.51 & 50.77 & 14.99 & 34.24 & 50.77 \\
\hline Dப-2 & 3300 & 6.70 & 52.40 & 40.90 & 17.26 & 41.84 & 40.90 \\
\hline Dப-2 & 3315 & 1.83 & 24.28 & 73.89 & 4.91 & 21.20 & 73.89 \\
\hline Dப-2 & 3330 & 4.98 & 33.85 & 61.17 & 12.32 & 26.50 & 61.17 \\
\hline Dப-2 & 3345 & 6.65 & 68.29 & 25.06 & 18.38 & 56.56 & 25.06 \\
\hline Dப-2 & 3360 & 6.84 & 55.53 & 37.64 & 17.04 & 45.33 & 37.64 \\
\hline Dப-2 & 3375 & 9.29 & 72.46 & 18.25 & 24.69 & 57.06 & 18.25 \\
\hline Dப-2 & 3390 & 6.16 & 68.61 & 25.24 & 16.93 & 57.83 & 25.24 \\
\hline Dப-2 & 3405 & 4.87 & 47.60 & 47.53 & 12.50 & 39.98 & 47.53 \\
\hline Dப-2 & 3420 & 3.32 & 31.91 & 64.78 & 8.97 & 26.26 & 64.78 \\
\hline Dப-2 & 3435 & 6.10 & 59.41 & 34.49 & 15.88 & 49.63 & 34.49 \\
\hline DU-2 & 3450 & 16.99 & 72.39 & 10.62 & 36.15 & 53.23 & 10.62 \\
\hline Dப-2 & 3465 & 12.62 & 78.81 & 8.56 & 34.22 & 57.22 & 8.56 \\
\hline Dப-2 & 3480 & 10.01 & 63.21 & 26.77 & 26.72 & 46.51 & 26.77 \\
\hline Dப-2 & 3495 & 12.76 & 75.68 & 11.56 & 34.54 & 53.90 & 11.56 \\
\hline Dப-2 & 3510 & 14.31 & 77.10 & 8.59 & 37.82 & 53.59 & 8.59 \\
\hline Dப-2 & 3525 & 7.93 & 61.81 & 30.26 & 20.79 & 48.95 & 30.26 \\
\hline Dப-2 & 3540 & 12.92 & 74.92 & 12.16 & 34.99 & 52.86 & 12.16 \\
\hline DU-2 & 3555 & 17.59 & 78.92 & 3.49 & 46.84 & 49.67 & 3.49 \\
\hline Dப-2 & 3570 & 20.75 & 77.26 & 1.99 & 51.95 & 46.06 & 1.99 \\
\hline Dப-2 & 3585 & 11.77 & 85.94 & 2.29 & 35.40 & 62.31 & 2.29 \\
\hline Dப-2 & 3600 & 13.80 & 82.55 & 3.65 & 37.92 & 58.43 & 3.65 \\
\hline Dப-2 & 3615 & 16.63 & 81.34 & 2.03 & 43.48 & 54.49 & 2.03 \\
\hline Dப-2 & 3630 & 17.01 & 82.53 & 0.47 & 46.15 & 53.38 & 0.47 \\
\hline Dப-2 & 3645 & 19.31 & 80.15 & 0.54 & 50.58 & 48.87 & 0.54 \\
\hline Dப-2 & 3660 & 18.76 & 70.10 & 11.14 & 46.90 & 41.96 & 11.14 \\
\hline
\end{tabular}




\begin{tabular}{|c|c|c|c|c|c|c|c|}
\hline Dப-2 & 3675 & 15.69 & 80.86 & 3.44 & 43.39 & 53.17 & 3.44 \\
\hline Dப-2 & 3690 & 18.10 & 80.32 & 1.57 & 48.72 & 49.71 & 1.57 \\
\hline Dப-2 & 3705 & 17.58 & 81.73 & 0.69 & 47.74 & 51.57 & 0.69 \\
\hline DU-2 & 3720 & 16.44 & 76.68 & 6.88 & 44.66 & 48.45 & 6.88 \\
\hline Dப-2 & 3735 & 10.62 & 63.59 & 25.79 & 28.48 & 45.73 & 25.79 \\
\hline Dப-2 & 3750 & 15.94 & 74.59 & 9.47 & 40.65 & 49.88 & 9.47 \\
\hline Dப-2 & 3765 & 5.34 & 46.49 & 48.17 & 16.63 & 35.20 & 48.17 \\
\hline DU-2 & 3780 & 2.67 & 22.93 & 74.41 & 8.41 & 17.19 & 74.41 \\
\hline Dப-2 & 3795 & 7.96 & 59.20 & 32.84 & 23.78 & 43.39 & 32.84 \\
\hline Dப-2 & 3810 & 13.39 & 69.60 & 17.01 & 40.28 & 42.71 & 17.01 \\
\hline Dப-2 & 3825 & 8.95 & 51.08 & 39.97 & 25.98 & 34.04 & 39.97 \\
\hline Dப-2 & 3840 & 3.80 & 29.66 & 66.54 & 11.64 & 21.82 & 66.54 \\
\hline Dப-2 & 3855 & 6.50 & 38.93 & 54.57 & 16.29 & 29.14 & 54.57 \\
\hline Dப-2 & 3870 & 2.21 & 14.70 & 83.09 & 6.64 & 10.27 & 83.09 \\
\hline Dப-2 & 3915 & 2.93 & 21.62 & 75.45 & 9.11 & 15.44 & 75.45 \\
\hline Dப-2 & 3930 & 3.03 & 18.00 & 78.97 & 9.14 & 11.89 & 78.97 \\
\hline Dப-2 & 3945 & 8.85 & 60.14 & 31.01 & 24.58 & 44.41 & 31.01 \\
\hline Dப-2 & 3960 & 1.59 & 10.59 & 87.82 & 5.31 & 6.87 & 87.82 \\
\hline DU-2 & 3975 & 3.12 & 19.27 & 77.61 & 9.28 & 13.12 & 77.61 \\
\hline Dப-2 & 3990 & 1.80 & 15.65 & 82.55 & 5.37 & 12.08 & 82.55 \\
\hline Dப-2 & 4005 & 16.75 & 63.75 & 19.50 & 38.89 & 41.61 & 19.50 \\
\hline Dப-2 & 4020 & 5.29 & 74.52 & 20.19 & 13.68 & 66.13 & 20.19 \\
\hline Dப-2 & 4035 & 0.50 & 9.25 & 90.25 & 1.99 & 7.76 & 90.25 \\
\hline DU-2 & 4050 & 1.26 & 16.96 & 81.77 & 3.95 & 14.28 & 81.77 \\
\hline Dப-2 & 4065 & 3.16 & 40.71 & 56.12 & 9.03 & 34.85 & 56.12 \\
\hline Dப-2 & 4080 & 0.76 & 8.37 & 90.87 & 3.17 & 5.96 & 90.87 \\
\hline DU-2 & 4095 & 1.39 & 13.15 & 85.45 & 4.60 & 9.95 & 85.45 \\
\hline Dப-2 & 4110 & 4.13 & 27.21 & 68.67 & 11.88 & 19.45 & 68.67 \\
\hline Dப-2 & 4125 & 0.57 & 8.32 & 91.11 & 2.47 & 6.42 & 91.11 \\
\hline Dப-2 & 4140 & 3.72 & 38.61 & 57.67 & 10.67 & 31.65 & 57.67 \\
\hline Dப-2 & 4155 & 2.35 & 28.26 & 69.39 & 6.21 & 24.40 & 69.39 \\
\hline Dப-2 & 4170 & 3.10 & 32.44 & 64.47 & 8.62 & 26.92 & 64.47 \\
\hline Dப-2 & 4185 & 1.40 & 14.53 & 84.07 & 4.28 & 11.65 & 84.07 \\
\hline Dப-2 & 4200 & 1.33 & 16.46 & 82.21 & 3.91 & 13.88 & 82.21 \\
\hline DU-2 & 4215 & 16.54 & 71.74 & 11.72 & 41.18 & 47.10 & 11.72 \\
\hline Dப-2 & 4230 & 4.86 & 63.45 & 31.69 & 12.83 & 55.48 & 31.69 \\
\hline Dப-2 & 4245 & 2.65 & 39.86 & 57.49 & 7.40 & 35.11 & 57.49 \\
\hline DU-2 & 4260 & 3.62 & 67.07 & 29.32 & 9.78 & 60.90 & 29.32 \\
\hline Dப-2 & 4275 & 4.17 & 67.33 & 28.51 & 11.99 & 59.50 & 28.51 \\
\hline Dப-2 & 4290 & 0.46 & 9.94 & 89.59 & 2.05 & 8.36 & 89.59 \\
\hline Dப-2 & 4305 & 1.94 & 18.85 & 79.22 & 5.97 & 14.81 & 79.22 \\
\hline Dப-2 & 4320 & 0.99 & 14.04 & 84.97 & 3.49 & 11.54 & 84.97 \\
\hline Dப-2 & 4335 & 2.63 & 46.97 & 50.40 & 7.75 & 41.84 & 50.40 \\
\hline Dப-2 & 4350 & 4.90 & 75.81 & 19.29 & 13.08 & 67.63 & 19.29 \\
\hline Dப-2 & 4365 & 5.70 & 65.02 & 29.28 & 13.92 & 56.80 & 29.28 \\
\hline DU-2 & 4380 & 3.19 & 61.99 & 34.81 & 7.91 & 57.28 & 34.81 \\
\hline Dப-2 & 4395 & 4.80 & 75.01 & 20.18 & 12.10 & 67.72 & 20.18 \\
\hline
\end{tabular}




\begin{tabular}{|c|c|c|c|c|c|c|c|}
\hline Dப-2 & 4410 & 8.55 & 55.89 & 35.56 & 21.68 & 42.76 & 35.56 \\
\hline DU-2 & 4425 & 1.38 & 26.64 & 71.98 & 3.53 & 24.49 & 71.98 \\
\hline Dப-2 & 4440 & 4.72 & 80.35 & 14.93 & 12.33 & 72.74 & 14.93 \\
\hline Dப-2 & 4455 & 4.73 & 66.04 & 29.23 & 12.08 & 58.69 & 29.23 \\
\hline Dப-2 & 4470 & 0.82 & 21.19 & 77.99 & 2.37 & 19.64 & 77.99 \\
\hline Dப-2 & 4485 & 3.98 & 71.56 & 24.46 & 10.07 & 65.47 & 24.46 \\
\hline Dப-2 & 4500 & 2.22 & 36.73 & 61.06 & 6.16 & 32.78 & 61.06 \\
\hline Dப-2 & 4515 & 2.96 & 45.41 & 51.63 & 7.96 & 40.41 & 51.63 \\
\hline Dப-2 & 4530 & 4.57 & 73.13 & 22.30 & 12.07 & 65.63 & 22.30 \\
\hline DU-2 & 4545 & 8.99 & 80.70 & 10.31 & 24.40 & 65.29 & 10.31 \\
\hline Dப-2 & 4560 & 4.09 & 63.35 & 32.56 & 11.13 & 56.32 & 32.56 \\
\hline Dப-2 & 4575 & 4.86 & 77.93 & 17.21 & 12.96 & 69.83 & 17.21 \\
\hline Dப-2 & 4590 & 7.79 & 46.59 & 45.62 & 18.58 & 35.80 & 45.62 \\
\hline Dப-2 & 4605 & 4.25 & 61.38 & 34.37 & 11.50 & 54.13 & 34.37 \\
\hline Dப-2 & 4620 & 4.16 & 58.54 & 37.30 & 11.11 & 51.59 & 37.30 \\
\hline Dப-2 & 4635 & 3.37 & 58.78 & 37.85 & 9.02 & 53.13 & 37.85 \\
\hline Dப-2 & 4650 & 3.56 & 61.04 & 35.39 & 9.24 & 55.37 & 35.39 \\
\hline DU-2 & 4665 & 4.76 & 77.35 & 17.89 & 12.31 & 69.80 & 17.89 \\
\hline Dப-2 & 4680 & 4.69 & 77.06 & 18.26 & 12.51 & 69.24 & 18.26 \\
\hline Dப-2 & 4695 & 3.95 & 69.17 & 26.88 & 10.28 & 62.84 & 26.88 \\
\hline Dப-2 & 4710 & 6.44 & 82.08 & 11.48 & 17.04 & 71.48 & 11.48 \\
\hline Dப-2 & 4725 & 16.81 & 79.08 & 4.12 & 41.90 & 53.99 & 4.12 \\
\hline Dப-2 & 4740 & 12.79 & 80.37 & 6.83 & 32.65 & 60.52 & 6.83 \\
\hline Dப-2 & 4755 & 10.49 & 82.13 & 7.39 & 27.52 & 65.09 & 7.39 \\
\hline Dப-2 & 4770 & 15.82 & 81.93 & 2.25 & 41.83 & 55.93 & 2.25 \\
\hline Dப-2 & 4785 & 13.47 & 81.17 & 5.37 & 35.35 & 59.28 & 5.37 \\
\hline Dப-2 & 4800 & 16.15 & 80.08 & 3.77 & 41.13 & 55.10 & 3.77 \\
\hline Dப-2 & 4815 & 17.21 & 80.36 & 2.43 & 44.12 & 53.46 & 2.43 \\
\hline Dப-2 & 4830 & 12.24 & 81.97 & 5.79 & 31.57 & 62.64 & 5.79 \\
\hline Dப-2 & 4845 & 9.12 & 85.80 & 5.08 & 23.10 & 71.83 & 5.08 \\
\hline Dப-2 & 4860 & 10.95 & 84.67 & 4.38 & 28.77 & 66.86 & 4.38 \\
\hline Dப-2 & 4875 & 17.53 & 80.65 & 1.83 & 41.42 & 56.75 & 1.83 \\
\hline Dப-2 & 4890 & 11.10 & 87.49 & 1.42 & 31.75 & 66.83 & 1.42 \\
\hline Dப-2 & 4905 & 25.28 & 74.28 & 0.44 & 59.33 & 40.23 & 0.44 \\
\hline Dப-2 & 4920 & 10.16 & 86.11 & 3.73 & 26.67 & 69.60 & 3.73 \\
\hline Dப-2 & 4935 & 2.69 & 14.18 & 83.13 & 6.90 & 9.97 & 83.13 \\
\hline Dப-2 & 5025 & 0.54 & 4.37 & 95.09 & 2.00 & 2.91 & 95.09 \\
\hline Dப-2 & 5115 & 0.74 & 3.62 & 95.64 & 2.33 & 2.02 & 95.64 \\
\hline Dப-2 & 5205 & 0.01 & 1.01 & 98.98 & 0.24 & 0.78 & 98.98 \\
\hline DU-2 & 5295 & 0.93 & 8.48 & 90.58 & 3.17 & 6.25 & 90.58 \\
\hline Dப-2 & 5385 & 0.68 & 8.60 & 90.71 & 2.50 & 6.78 & 90.71 \\
\hline Dப-2 & 5475 & 0.71 & 11.32 & 87.97 & 2.61 & 9.42 & 87.97 \\
\hline Dப-2 & 5550 & 0.42 & 4.72 & 94.86 & 1.62 & 3.52 & 94.86 \\
\hline OCG & 10 & 9.27 & 81.97 & 8.76 & 31.42 & 59.82 & 8.76 \\
\hline OCG & 20 & 10.80 & 87.02 & 2.17 & 33.87 & 63.96 & 2.17 \\
\hline OCG & 30 & 10.93 & 86.79 & 2.28 & 33.84 & 63.88 & 2.28 \\
\hline OCG & 40 & 10.86 & 86.88 & 2.26 & 33.71 & 64.03 & 2.26 \\
\hline
\end{tabular}




\begin{tabular}{|c|c|c|c|c|c|c|c|}
\hline OCG & 50 & 10.97 & 87.03 & 2.00 & 34.45 & 63.55 & 2.00 \\
\hline OCG & 60 & 10.98 & 87.40 & 1.62 & 35.32 & 63.06 & 1.62 \\
\hline OCG & 70 & 10.61 & 87.13 & 2.26 & 33.89 & 63.85 & 2.26 \\
\hline OCG & 80 & 9.46 & 84.81 & 5.73 & 28.55 & 65.71 & 5.73 \\
\hline OCG & 90 & 9.99 & 84.98 & 5.02 & 29.02 & 65.96 & 5.02 \\
\hline OCG & 100 & 9.26 & 84.82 & 5.92 & 26.53 & 67.55 & 5.92 \\
\hline OCG & 110 & 13.46 & 84.83 & 1.70 & 43.72 & 54.58 & 1.70 \\
\hline OCG & 120 & 10.15 & 85.53 & 4.32 & 30.52 & 65.16 & 4.32 \\
\hline OCG & 130 & 8.93 & 86.51 & 4.56 & 25.84 & 69.61 & 4.56 \\
\hline OCG & 140 & 10.89 & 87.11 & 2.00 & 33.64 & 64.36 & 2.00 \\
\hline OCG & 150 & 10.36 & 86.86 & 2.78 & 33.01 & 64.21 & 2.78 \\
\hline OCG & 160 & 8.26 & 82.88 & 8.86 & 24.69 & 66.45 & 8.86 \\
\hline OCG & 170 & 8.00 & 87.24 & 4.76 & 24.36 & 70.88 & 4.76 \\
\hline OCG & 180 & 8.90 & 87.71 & 3.38 & 26.98 & 69.64 & 3.38 \\
\hline OCG & 190 & 11.57 & 86.55 & 1.88 & 38.40 & 59.72 & 1.88 \\
\hline OCG & 200 & 9.26 & 86.85 & 3.89 & 28.73 & 67.38 & 3.89 \\
\hline OCG & 210 & 7.69 & 80.18 & 12.12 & 21.15 & 66.73 & 12.12 \\
\hline OCG & 220 & 8.75 & 86.13 & 5.12 & 24.60 & 70.28 & 5.12 \\
\hline OCG & 230 & 8.48 & 86.40 & 5.11 & 24.59 & 70.30 & 5.11 \\
\hline OCG & 240 & 8.43 & 87.56 & 4.01 & 25.63 & 70.36 & 4.01 \\
\hline OCG & 250 & 8.25 & 86.48 & 5.27 & 24.15 & 70.58 & 5.27 \\
\hline OCG & 260 & 8.80 & 88.00 & 3.20 & 26.66 & 70.13 & 3.20 \\
\hline OCG & 270 & 7.90 & 87.87 & 4.23 & 23.07 & 72.69 & 4.23 \\
\hline OCG & 280 & 8.61 & 86.96 & 4.44 & 25.90 & 69.66 & 4.44 \\
\hline OCG & 290 & 7.73 & 86.53 & 5.74 & 21.96 & 72.30 & 5.74 \\
\hline OCG & 300 & 7.57 & 86.40 & 6.03 & 23.00 & 70.96 & 6.03 \\
\hline OCG & 310 & 8.65 & 85.79 & 5.55 & 25.57 & 68.88 & 5.55 \\
\hline OCG & 320 & 9.00 & 85.81 & 5.18 & 25.30 & 69.51 & 5.18 \\
\hline OCG & 330 & 6.67 & 78.97 & 14.36 & 17.68 & 67.96 & 14.36 \\
\hline OCG & 340 & 7.60 & 84.60 & 7.80 & 21.51 & 70.70 & 7.80 \\
\hline OCG & 350 & 8.00 & 82.69 & 9.31 & 22.56 & 68.13 & 9.31 \\
\hline OCG & 360 & 7.48 & 84.47 & 8.04 & 21.15 & 70.81 & 8.04 \\
\hline OCG & 370 & 7.82 & 77.17 & 15.01 & 21.42 & 63.57 & 15.01 \\
\hline OCG & 380 & 7.29 & 83.25 & 9.46 & 20.15 & 70.39 & 9.46 \\
\hline OCG & 390 & 8.15 & 88.51 & 3.34 & 24.37 & 72.28 & 3.34 \\
\hline OCG & 400 & 7.05 & 87.04 & 5.92 & 19.54 & 74.54 & 5.92 \\
\hline OCG & 410 & 7.18 & 85.76 & 7.06 & 20.12 & 72.82 & 7.06 \\
\hline OCG & 420 & 8.27 & 85.82 & 5.91 & 24.50 & 69.58 & 5.91 \\
\hline OCG & 430 & 8.80 & 86.09 & 5.11 & 26.21 & 68.69 & 5.11 \\
\hline OCG & 440 & 9.67 & 82.74 & 7.59 & 28.15 & 64.25 & 7.59 \\
\hline OCG & 450 & 9.23 & 85.93 & 4.85 & 26.89 & 68.26 & 4.85 \\
\hline OCG & 460 & 7.38 & 85.52 & 7.10 & 23.11 & 69.79 & 7.10 \\
\hline OCG & 470 & 7.10 & 85.75 & 7.15 & 20.72 & 72.13 & 7.15 \\
\hline OCG & 480 & 7.41 & 84.93 & 7.67 & 21.58 & 70.75 & 7.67 \\
\hline OCG & 490 & 7.86 & 87.96 & 4.18 & 25.83 & 69.99 & 4.18 \\
\hline OCG & 500 & 6.91 & 85.68 & 7.41 & 23.30 & 69.29 & 7.41 \\
\hline OCG & 510 & 6.81 & 87.64 & 5.54 & 23.00 & 71.45 & 5.54 \\
\hline
\end{tabular}




\begin{tabular}{|c|c|c|c|c|c|c|c|}
\hline OCG & 520 & 6.68 & 87.44 & 5.88 & 20.69 & 73.43 & 5.88 \\
\hline OCG & 530 & 7.25 & 87.04 & 5.70 & 22.48 & 71.81 & 5.70 \\
\hline OCG & 540 & 7.70 & 86.52 & 5.78 & 24.21 & 70.01 & 5.78 \\
\hline OCG & 550 & 6.76 & 87.24 & 6.01 & 20.18 & 73.82 & 6.01 \\
\hline OCG & 560 & 8.37 & 85.13 & 6.50 & 26.81 & 66.69 & 6.50 \\
\hline OCG & 570 & 7.83 & 88.71 & 3.46 & 26.10 & 70.43 & 3.46 \\
\hline OCG & 580 & 6.87 & 84.60 & 8.53 & 21.24 & 70.23 & 8.53 \\
\hline OCG & 590 & 5.92 & 84.04 & 10.04 & 20.50 & 69.46 & 10.04 \\
\hline OCG & 600 & 7.35 & 87.74 & 4.91 & 25.07 & 70.02 & 4.91 \\
\hline OCG & 610 & 6.04 & 85.99 & 7.97 & 20.75 & 71.28 & 7.97 \\
\hline OCG & 620 & 6.58 & 86.92 & 6.50 & 19.48 & 74.02 & 6.50 \\
\hline OCG & 630 & 7.19 & 88.96 & 3.85 & 26.91 & 69.24 & 3.85 \\
\hline OCG & 640 & 5.89 & 84.66 & 9.45 & 20.39 & 70.16 & 9.45 \\
\hline OCG & 650 & 5.90 & 85.25 & 8.85 & 18.93 & 72.22 & 8.85 \\
\hline OCG & 660 & 8.11 & 86.42 & 5.47 & 28.75 & 65.79 & 5.47 \\
\hline OCG & 670 & 6.78 & 87.07 & 6.15 & 22.14 & 71.71 & 6.15 \\
\hline OCG & 680 & 6.88 & 77.81 & 15.31 & 22.55 & 62.13 & 15.31 \\
\hline OCG & 690 & 6.21 & 76.99 & 16.80 & 20.07 & 63.13 & 16.80 \\
\hline OCG & 700 & 5.12 & 84.78 & 10.10 & 13.87 & 76.03 & 10.10 \\
\hline OCG & 710 & 7.73 & 85.50 & 6.77 & 24.72 & 68.52 & 6.77 \\
\hline OCG & 720 & 6.22 & 85.51 & 8.28 & 19.66 & 72.06 & 8.28 \\
\hline OCG & 730 & 5.41 & 85.22 & 9.37 & 14.99 & 75.64 & 9.37 \\
\hline OCG & 740 & 4.97 & 78.20 & 16.83 & 13.38 & 69.79 & 16.83 \\
\hline OCG & 750 & 6.76 & 81.18 & 12.05 & 18.71 & 69.23 & 12.05 \\
\hline OCG & 800 & 6.16 & 83.44 & 10.41 & 17.49 & 72.10 & 10.41 \\
\hline OCG & 810 & 5.88 & 83.71 & 10.41 & 17.35 & 72.24 & 10.41 \\
\hline OCG & 820 & 6.02 & 82.11 & 11.86 & 16.91 & 71.22 & 11.86 \\
\hline SLS & 150 & 9.48 & 87.35 & 3.18 & 39.25 & 57.57 & 3.18 \\
\hline SLS & 160 & 11.01 & 86.68 & 2.31 & 44.19 & 53.50 & 2.31 \\
\hline SLS & 170 & 13.64 & 85.58 & 0.78 & 51.34 & 47.88 & 0.78 \\
\hline SLS & 180 & 7.77 & 87.33 & 4.90 & 33.37 & 61.73 & 4.90 \\
\hline SLS & 190 & 12.23 & 84.79 & 2.98 & 43.62 & 53.40 & 2.98 \\
\hline SLS & 200 & 13.58 & 82.94 & 3.48 & 45.39 & 51.12 & 3.48 \\
\hline SLS & 210 & 9.16 & 83.48 & 7.36 & 29.63 & 63.01 & 7.36 \\
\hline SLS & 220 & 10.48 & 85.37 & 4.15 & 35.96 & 59.90 & 4.15 \\
\hline SLS & 230 & 10.47 & 84.24 & 5.29 & 36.23 & 58.49 & 5.29 \\
\hline SLS & 240 & 9.21 & 82.30 & 8.49 & 33.65 & 57.85 & 8.49 \\
\hline SLS & 250 & 8.81 & 86.60 & 4.59 & 29.13 & 66.29 & 4.59 \\
\hline SLS & 260 & 8.88 & 88.22 & 2.90 & 30.21 & 66.89 & 2.90 \\
\hline SLS & 270 & 8.37 & 88.75 & 2.88 & 29.70 & 67.41 & 2.88 \\
\hline SLS & 280 & 7.20 & 90.75 & 2.04 & 23.83 & 74.13 & 2.04 \\
\hline SLS & 290 & 5.91 & 85.06 & 9.03 & 20.37 & 70.60 & 9.03 \\
\hline SLS & 300 & 6.14 & 88.88 & 4.98 & 20.36 & 74.67 & 4.98 \\
\hline SLS & 310 & 8.81 & 86.57 & 4.62 & 29.64 & 65.75 & 4.62 \\
\hline SLS & 320 & 6.55 & 85.67 & 7.78 & 22.05 & 70.17 & 7.78 \\
\hline SLS & 330 & 6.99 & 88.47 & 4.54 & 23.02 & 72.43 & 4.54 \\
\hline SLS & 340 & 7.14 & 88.57 & 4.28 & 23.44 & 72.28 & 4.28 \\
\hline
\end{tabular}




\begin{tabular}{|c|c|c|c|c|c|c|c|}
\hline SLS & 350 & 6.69 & 88.48 & 4.83 & 21.81 & 73.36 & 4.83 \\
\hline SLS & 360 & 6.26 & 87.58 & 6.17 & 19.84 & 73.99 & 6.17 \\
\hline SLS & 370 & 6.18 & 87.36 & 6.45 & 19.40 & 74.14 & 6.45 \\
\hline SLS & 380 & 5.45 & 80.03 & 14.52 & 17.84 & 67.64 & 14.52 \\
\hline SLS & 390 & 5.65 & 82.64 & 11.71 & 17.64 & 70.65 & 11.71 \\
\hline SLS & 400 & 6.12 & 87.42 & 6.46 & 18.41 & 75.13 & 6.46 \\
\hline SLS & 410 & 7.61 & 89.99 & 2.39 & 26.11 & 71.50 & 2.39 \\
\hline SLS & 420 & 7.57 & 89.79 & 2.65 & 26.72 & 70.63 & 2.65 \\
\hline SLS & 430 & 8.39 & 81.10 & 10.51 & 32.68 & 56.81 & 10.51 \\
\hline SLS & 440 & 6.03 & 80.41 & 13.56 & 25.01 & 61.43 & 13.56 \\
\hline SLS & 450 & 5.46 & 83.57 & 10.97 & 20.72 & 68.30 & 10.97 \\
\hline SLS & 460 & 10.16 & 85.17 & 4.67 & 33.83 & 61.50 & 4.67 \\
\hline SLS & 470 & 7.68 & 86.59 & 5.73 & 26.20 & 68.07 & 5.73 \\
\hline SLS & 480 & 7.16 & 86.11 & 6.73 & 24.30 & 68.96 & 6.73 \\
\hline SLS & 490 & 6.11 & 87.18 & 6.72 & 19.80 & 73.48 & 6.72 \\
\hline SLS & 500 & 6.20 & 87.82 & 5.98 & 19.53 & 74.49 & 5.98 \\
\hline SLS & 510 & 6.28 & 87.86 & 5.86 & 20.27 & 73.87 & 5.86 \\
\hline SLS & 520 & 8.32 & 89.08 & 2.61 & 29.67 & 67.72 & 2.61 \\
\hline SLS & 530 & 8.08 & 81.56 & 10.37 & 31.75 & 57.88 & 10.37 \\
\hline SLS & 540 & 5.69 & 84.43 & 9.88 & 21.63 & 68.49 & 9.88 \\
\hline SLS & 550 & 7.48 & 86.81 & 5.71 & 23.43 & 70.85 & 5.71 \\
\hline SLS & 560 & 7.90 & 85.03 & 7.07 & 23.37 & 69.56 & 7.07 \\
\hline SLS & 570 & 9.12 & 87.39 & 3.48 & 26.97 & 69.55 & 3.48 \\
\hline SLS & 580 & 7.99 & 87.38 & 4.62 & 23.73 & 71.65 & 4.62 \\
\hline SLS & 590 & 8.93 & 87.20 & 3.88 & 26.26 & 69.86 & 3.88 \\
\hline SLS & 600 & 6.68 & 68.95 & 24.37 & 20.30 & 55.33 & 24.37 \\
\hline SLS & 610 & 5.90 & 86.77 & 7.33 & 18.10 & 74.58 & 7.33 \\
\hline SLS & 620 & 6.12 & 89.25 & 4.63 & 19.39 & 75.99 & 4.63 \\
\hline SLS & 630 & 7.97 & 82.46 & 9.57 & 32.14 & 58.29 & 9.57 \\
\hline SLS & 640 & 6.61 & 84.87 & 8.52 & 23.08 & 68.41 & 8.52 \\
\hline SLS & 650 & 7.76 & 87.55 & 4.69 & 23.59 & 71.71 & 4.69 \\
\hline SLS & 660 & 8.29 & 87.83 & 3.87 & 24.21 & 71.92 & 3.87 \\
\hline SLS & 670 & 8.42 & 82.56 & 9.02 & 25.07 & 65.91 & 9.02 \\
\hline SLS & 680 & 5.64 & 56.87 & 37.49 & 17.74 & 44.77 & 37.49 \\
\hline SLS & 690 & 1.13 & 13.82 & 85.05 & 3.97 & 10.98 & 85.05 \\
\hline SLS & 700 & 0.63 & 10.55 & 88.82 & 2.68 & 8.50 & 88.82 \\
\hline SLS & 710 & 0.63 & 9.96 & 89.41 & 2.40 & 8.19 & 89.41 \\
\hline SLS & 720 & 1.86 & 16.43 & 81.71 & 5.57 & 12.72 & 81.71 \\
\hline SLS & 730 & 1.45 & 19.62 & 78.93 & 4.69 & 16.38 & 78.93 \\
\hline SLS & 740 & 1.27 & 10.52 & 88.21 & 4.28 & 7.51 & 88.21 \\
\hline SLS & 750 & 1.10 & 13.75 & 85.16 & 3.98 & 10.86 & 85.16 \\
\hline SLS & 760 & 0.69 & 9.03 & 90.28 & 2.81 & 6.90 & 90.28 \\
\hline SLS & 770 & 1.11 & 10.00 & 88.89 & 3.94 & 7.17 & 88.89 \\
\hline SLS & 780 & 0.99 & 12.57 & 86.44 & 3.63 & 9.94 & 86.44 \\
\hline SLS & 790 & 0.52 & 7.53 & 91.96 & 2.50 & 5.54 & 91.96 \\
\hline SLS & 800 & 0.34 & 6.47 & 93.19 & 1.88 & 4.92 & 93.19 \\
\hline SLS & 810 & 0.63 & 8.85 & 90.52 & 2.44 & 7.04 & 90.52 \\
\hline
\end{tabular}




\begin{tabular}{|c|c|c|c|c|c|c|c|}
\hline SLS & 820 & 0.56 & 8.66 & 90.78 & 2.49 & 6.73 & 90.78 \\
\hline SLS & 830 & 1.30 & 15.48 & 83.22 & 4.23 & 12.55 & 83.22 \\
\hline SLS & 840 & 0.63 & 9.29 & 90.08 & 2.64 & 7.29 & 90.08 \\
\hline SLS & 850 & 0.49 & 9.79 & 89.72 & 2.19 & 8.09 & 89.72 \\
\hline SLS & 860 & 1.02 & 12.42 & 86.56 & 3.73 & 9.71 & 86.56 \\
\hline SLS & 870 & 0.51 & 8.28 & 91.21 & 2.17 & 6.62 & 91.21 \\
\hline SLS & 880 & 0.11 & 2.63 & 97.26 & 0.77 & 1.96 & 97.26 \\
\hline SLS & 890 & 1.08 & 11.38 & 87.53 & 3.79 & 8.68 & 87.53 \\
\hline SLS & 900 & 3.81 & 67.44 & 28.75 & 10.65 & 60.60 & 28.75 \\
\hline SLS & 910 & 1.07 & 13.13 & 85.80 & 3.32 & 10.88 & 85.80 \\
\hline SLS & 920 & 1.31 & 8.94 & 89.75 & 3.48 & 6.77 & 89.75 \\
\hline SLS & 930 & 0.84 & 6.68 & 92.48 & 2.57 & 4.94 & 92.48 \\
\hline SLS & 940 & 0.80 & 9.61 & 89.59 & 2.53 & 7.88 & 89.59 \\
\hline SLS & 950 & 0.84 & 9.68 & 89.48 & 2.83 & 7.70 & 89.48 \\
\hline SLS & 960 & 0.48 & 5.66 & 93.86 & 1.72 & 4.42 & 93.86 \\
\hline SLS & 970 & 0.77 & 6.61 & 92.62 & 2.46 & 4.91 & 92.62 \\
\hline SLS & 980 & 0.52 & 8.32 & 91.15 & 2.10 & 6.74 & 91.15 \\
\hline SLS & 990 & 0.74 & 9.58 & 89.68 & 2.98 & 7.34 & 89.68 \\
\hline SLS & 1000 & 0.57 & 8.19 & 91.24 & 2.47 & 6.29 & 91.24 \\
\hline SLS & 1010 & 1.05 & 13.06 & 85.89 & 3.73 & 10.38 & 85.89 \\
\hline SLS & 1020 & 0.11 & 2.38 & 97.51 & 0.89 & 1.60 & 97.51 \\
\hline SLS & 1030 & 0.88 & 9.35 & 89.76 & 2.92 & 7.32 & 89.76 \\
\hline SLS & 1040 & 1.28 & 15.72 & 82.99 & 4.19 & 12.81 & 82.99 \\
\hline SLS & 1050 & 1.81 & 18.64 & 79.55 & 5.49 & 14.96 & 79.55 \\
\hline SLS & 1060 & 0.41 & 4.08 & 95.50 & 1.56 & 2.94 & 95.50 \\
\hline SLS & 1070 & 0.64 & 10.45 & 88.91 & 2.32 & 8.77 & 88.91 \\
\hline SLS & 1080 & 0.67 & 8.22 & 91.10 & 2.39 & 6.51 & 91.10 \\
\hline SLS & 1090 & 0.76 & 8.06 & 91.18 & 2.39 & 6.43 & 91.18 \\
\hline SLS & 1100 & 0.96 & 14.14 & 84.90 & 2.56 & 12.54 & 84.90 \\
\hline SLS & 1110 & 1.02 & 13.16 & 85.82 & 3.04 & 11.14 & 85.82 \\
\hline SLS & 1120 & 1.20 & 16.44 & 82.37 & 3.07 & 14.56 & 82.37 \\
\hline SLS & 1130 & 0.77 & 9.42 & 89.82 & 2.45 & 7.73 & 89.82 \\
\hline SLS & 1140 & 1.15 & 10.32 & 88.53 & 3.55 & 7.92 & 88.53 \\
\hline SLS & 1150 & 1.22 & 13.63 & 85.15 & 3.53 & 11.31 & 85.15 \\
\hline SLS & 1160 & 1.15 & 8.91 & 89.94 & 3.55 & 6.51 & 89.94 \\
\hline SLS & 1170 & 3.75 & 76.27 & 19.98 & 8.75 & 71.27 & 19.98 \\
\hline SLS & 1180 & 4.17 & 72.59 & 23.25 & 10.84 & 65.91 & 23.25 \\
\hline SLS & 1190 & 4.96 & 81.73 & 13.31 & 12.46 & 74.24 & 13.31 \\
\hline SLS & 1200 & 5.43 & 82.24 & 12.33 & 14.36 & 73.31 & 12.33 \\
\hline
\end{tabular}

